\title{
Toezicht op de Belgische energiemarkten $^{\star}$
}

\author{
Kurt Deketelaere ${ }^{1}$, Bram Delvaux ${ }^{2}$ en Stefan Tormans 3
}

\section{Inleiding}

De liberalisering van de Europese energiemarkten is een Europees proces. Via in nationale wetgeving om te zetten richtlijnen kregen - eerst de niet-huishoudelijke, en later de huishoudelijke - afnemers de mogelijkheid uiteindelijk vrij hun leverancier van aardgas en elektriciteit te kiezen.

Met het oog op het bevorderen van de komst en de penetratie in de markt van bijkomende economische operatoren - en dit niet alleen tijdens het liberaliseringsproces, maar ook, en vooral, na de opening van de energiemarkten - alsook als behartiger van het algemeen belang terzake, hebben de onderscheiden wetgevende organen regulerende instanties in het leven geroepen. ${ }^{4}$ De werking van de elektriciteits- en de aardgasmarkten is immers dermate technisch, dat de wetgever ervoor opteerde om bijzondere, gespecialiseerde instellingen, regulatoren, aan te duiden voor de behartiging van het publieke belang.

In de meest ruime zin van het woord, dient een regulator te beantwoorden aan de verwachting om 'de correcte werking van een complex systeem te verzekeren'. ${ }^{5}$ Daarom zijn hun beslissingen veelal het voorwerp zijn van betwistingen, niet alleen door de (bestaande) producenten en netbeheerders, maar ook door afnemers. De definitie is ruim, en geldt voor alle regulatoren die worden/zijn opgericht in de verschillende te liberaliseren markten (bijv. telecom, post, water, enz.), en niet alleen voor de energiemarkten.

* Deze bijdrage is geschreven in eigen naam en onder de uitsluitende verantwoordelijkheid van de auteurs; de in deze bijdrage opgenomen opinies en stellingen verbinden enkel en alleen de auteurs.

I. Secretaris-generaal van de League of European Research Universities (LERU), Buitengewoon Hoogleraar K.U.Leuven en University of Dundee.

2. Doctoraatsassistent aan het Instituut voor Milieu- en Energierecht (IMER) van de rechtsfaculteit, Collegium Falconis van de K.U.Leuven en het Departement Elektrotechniek - ESAT - ELECTA, Faculteit Ingenieurswetenschappen, K.U. Leuven.

3. Advocaat (balie Hasselt) en Vrijwillig Wetenschappelijk Medewerker IMER, K.U.Leuven.

4. Zie, in het algemeen, E. Wymeersch, 'Aspecten van toezicht', R.W. 2004-2005, nr.6, 203.

5. Zie ook A.L. Durviaux, 'La sauvegarde des préoccupations d'intérêt général dans la régulation économique (en particulier ; le service postal universel)' in Commission droit et vie des affaires (ed.), La régulation économique dans la vie des affaires, Brussel, Bruylant, 2007, 55, die verwijst naar A. Laget-Annamayer, La régulation des services publics en réseaux, Télécommunications et électricité, L.G.D.J., Bruylant, 2002, pp. 2-3. 
De regulatoren hebben een eigen rechtspositie. Vanuit deze rechtspositie beogen zij de concurrentie op de energiemarkt aan te zwengelen, de wetgeving en het algemeen belang in het achterhoofd indachtig, waarbij zij toezicht houden op de verschillende marktactoren.

Daar waar onze Nederlandse collega's in hun preadvies het financieel toezicht in Nederland hebben behandeld, is een vergelijking met de energiesector voorzeker verdienstelijk, maar niet steeds mogelijk. Alleszins geldt dat het toezicht in de sector van financiële dienstverlening van oudere datum is, meer beproefd, en om die reden wellicht meer uitgewerkt. De energiesector wordt trouwens gekenmerkt door bijzonder technische regelgeving voor een veelheid aan partijen - producenten, transmissienetbeheerder/vervoerder, distributienetbeheerders, leveranciers en afnemers (huishoudelijke en niet-huishoudelijke). De netbeheerders zijn daarbij - minstens gedeeltelijk - van publiekrechtelijke aard, terwijl producenten, leveranciers en afnemers - de overheid als afnemer uiteraard uitgezonderd - privaatrechtelijke (rechts) personen zijn.

Producenten, leveranciers en afnemers behartigen aldus niet het publiek belang. De overheid is hier immers geen aandeelhouder. Dit maakt de vergelijking met de financiële sector weliswaar mogelijk, waar de aandeelhouders altijd al private partijen zijn geweest. Voor beide sectoren is toezicht en regulering alleszins noodzakelijk teneinde een vlot werkende markt, inbegrepen de behartiging van het algemeen belang, te verzekeren.

In deze bijdrage zal het bestaande kader van de regulatoren in de Belgische energiemarkten worden doorgelicht. Noteer evenwel dat deze bijdrage geen analyse bevat van het toezicht door de mededingsautoriteiten op de Belgische energiemarkten.

Een eerste deel schetst de bevoegdheidsverdeling van het Belgische energiebeleid. Het tweede en het derde deel behandelen de vorm, samenstelling, werking, bevoegdheden en taken van de vier regulatoren. Een vierde deel beschrijft kort de principes van het derde pakket maatregelen die door de nationale lidstaten moeten worden omgezet tegen uiterlijk 3 maart 20II. We halen ook kort de wijzingen voor de regulatoren aan. Een vijfde deel behandelt de beroepen tegen de beslissingen van de regulator. Een zesde deel gaat over de bijzondere rol van de regulator ter bescherming van de consument. Een zevende deel behandelt tenslotte de aansprakelijkheid van de regulatoren, waarna deze bijdrage wordt afgesloten met een aantal concluderende bemerkingen.

\section{Bevoegdheidsverdeling van het Belgische energiebeleid}

Alvorens dieper in te gaan op het juridisch kader van de diverse regulatoren in de Belgische elektriciteits- en gasmarkten zal kort worden stilgestaan bij de bevoegdheidsverdeling tussen de federale en gewestelijke overheden met betrekking tot het 
energiebeleid. ${ }^{6}$ Deze bevoegdheidsverdeling werd vastgelegd in de bijzondere wet van 8 augustus I980 tot hervorming der instellingen (hierna: 'BWHI') en heeft ertoe geleid dat in België, los van de mededingingsautoriteiten, vier regulatoren actief zijn in de elektriciteits- en gasmarkt. ${ }^{7}$

Op grond van het artikel 6, SI, VII van de BWHI 'zijn de gewesten bevoegd voor de gewestelijke aspecten van het energiebeleid, en in ieder geval:

a) de distributie en het plaatselijke vervoer van elektriciteit door middel van netten waarvan de nominale spanning lager is dan of gelijk is aan 70.000 volt;

b) de openbare gasdistributie;

c) de aanwending van mijngas en van gas afkomstig van hoogovens;

d) de netten voor warmtevoorziening op afstand;

e) de valorisatie van steenbergen;

f) de nieuwe energiebronnen met uitzondering van deze die verband houden met de kernenergie;

g) de terugwinning van energie door de nijverheid en andere gebruikers;

h) het rationeel energieverbruik.'

De federale overheid is daarentegen op grond van het artikel 6, SI, VII van de BWHI bevoegd voor de aangelegenheden die wegens hun technische en economische ondeelbaarheid een gelijke behandeling op nationaal vlak behoeven, te weten:

'a) het nationaal uitrustingsprogramma in de elektriciteitssector;

b) de kernbrandstofcyclus;

c) de grote infrastructuren voor de stockering; het vervoer en de productie van energie;

d) de tarieven.' 8

In de rechtsleer is er over de precieze inhoud en strekking van deze bepalingen geen eensgezindheid. ${ }^{9}$ Enerzijds geeft de BWHI een opsomming van bevoegdheden die 'in ieder geval' tot de bevoegdheden van de gewesten behoren. Bij een eerste lezing geven de woorden 'in ieder geval' de indruk dat de opsomming van de 'gewestelijke aspecten van het energiebeleid' een niet-limitatieve opsomming is. Hierdoor

6. Zie B. Delvaux, 'Vrijmaking van de Belgische elektriciteits- en gasmarkt - Een Gordiaanse knoop?', SEW 2007, afl. 2, p. 66-78.

7. Zie hierna.

8. Voor een verdere analyse zie L. Deridder, 'Het Energiebeleid' in G. Van Haegendoren (ed.), De bevoegdheidsverdeling in het federale België, Brugge, die Keure, 2000, 82 p. en L. Deridder, 'Handboek gas- en elektriciteitsliberalisering', Antwerpen, Intersentia, 2003, p. I27-20I.

9. T. Vanden Borre, 'De federale ombudsdienst voor elektriciteit en gas: naar een nieuw artikel 2', in T. Vanden Borre (ed.), De vrijmaking van de elektriciteits- en gasmarkt: de federale wetgeving in een stroomversnelling?, Antwerpen, Intersentia, 2006, p. I43-I5; C. Vanderveeren, 'Regulators in a Federal Regime: the Belgian Case', in M. Roggenkamp en U. Hammer (ed.), European Energy Law Report II, Antwerpen, Intersentia, 2005, p. 68-72 en L. Deridder, 'Het Energiebeleid' in G. Van Haegendoren (ed.), l.c., p. 44-75. 
zou men van oordeel kunnen zijn dat de gewesten ook bevoegd zijn voor de andere 'gewestelijke aspecten van het energiebeleid'. Wat precies onder deze 'gewestelijke aspecten van het energiebeleid' dient te worden verstaan is onduidelijk aangezien de BWHI hier geen definitie over bevat. Anderzijds voorziet de BWHI in een opsomming van federale bevoegdheden 'die wegens hun technische en economische ondeelbaarheid een gelijke behandeling op nationaal vlak behoeven, te weten [...]'. Hierbij stelt zich de vraag of de woorden 'te weten', die werden aangevuld bij de bijzondere wet van 8 augustus I9 88 tot wijziging van de BWHI, ${ }^{\text {Io }}$ in de eerste volzin over federale bevoegdheden in het energiebeleid al dan niet verwijzen naar een limitatieve opsomming.

Op grond van deze bepalingen in de BWHI met betrekking tot het energiebeleid en de beperkte verduidelijking in de voorbereidende werken is in de rechtsleer de vraag ontstaan of kan worden aangenomen dat de gewestelijke energiebevoegdheden niet-limitatief zijn opgesomd in de BWHI, terwijl de federale energiebevoegdheden daarentegen wel limitatief zijn. ${ }^{\text {II }}$ De bevoegde Minister verklaarde tijdens de bespreking van de wijzigingen aan de BWHI in de Senaat 'dat de aangelegenheden die wegens hun technische en economische ondeelbaarheid een gelijke behandeling op nationaal vlak behoeven limitatief en volledig worden opgesomd na de woorden "te weten". ${ }^{22}$ Hieruit leidde bepaalde rechtsleer af dat enkel voor de limitatief opgesomde beleidsdomeinen de nationale overheid ook de gewestelijke aspecten van het energiebeleid kan uitwerken. Bijgevolg zijn er buiten deze beleidsdomeinen geen gewestelijke aspecten van het energiebeleid vatbaar voor federale inmenging. ${ }^{13}$

Los van het voorgaande stelde de bevoegde minister 'tevens dat de nationale overheid bevoegd is voor de niet-gewestelijke aspecten van het energiebeleid'. ${ }^{4}$ Daarnaast kan uit de memorie van toelichting bij de BWHI worden afgeleid dat de aan de federale overheid toegekende bevoegdheden in het kader van het energiebeleid op geen enkele wijze de residuaire bevoegdheid van de federale overheid wijzigen. De residuaire bevoegdheid blijft aan de federale overheid toebehoren. Op basis van het huidige Belgische grondwettelijk stelsel zijn de bevoegdheden van de gewesten en de gemeenschappen immers toegewezen bevoegdheden.

Tot op heden behoudt de federale overheid de residuaire bevoegdheden en bijgevolg ook de bevoegdheden in het kader van het energiebeleid die niet werden toegewezen aan de gewesten. In de toekomst kan dit mogelijks veranderen na de inwerkingtreding van het nieuwe artikel 35 van de Grondwet, dat precies in het omgekeerde voorziet, waarbij:

\footnotetext{
Io. B.S. I3 augustus ig88.

II. T. Vanden Borre, 'De federale ombudsdienst voor elektriciteit en gas: naar een nieuw artikel 27', in T. Vanden Borre (ed.), l.c., p. I44.

I2. Parl. St. Senaat, buitengewone zitting, I988, nr. 405-2, III.

I3. L. Deridder, 'Het Energiebeleid' in G. Van Haegendoren (ed.), l.c., p. 44-46 en L. Deridder, Handboek gas- en elektriciteitsliberalisering, o.c., p. I34-I37.

I4. Parl. St. Senaat, buitengewone zitting, I988, nr. 405-2, III.
} 
'De federale overheid [...] slechts bevoegd [is] voor de aangelegenheden die de Grondwet en de wetten, krachtens de Grondwet zelf uitgevaardigd, haar uitdrukkelijk toekennen. De gemeenschappen of de gewesten zijn, ieder wat hem betreft, bevoegd voor de overige aangelegenheden onder de voorwaarden en op de wijze bepaald door de wet.'

Dergelijke wettelijke opsomming van de federale bevoegdheden werd tot op heden nog niet opgesteld en bijgevolg is artikel 35 van de Grondwet nog niet inwerking getreden.

Tevens kan in dit kader worden gewezen op artikel $6, \S_{3}, 2^{\circ}$ en $3^{\circ}$ van de BWHI op grond waarvan de betrokken regeringen en 'de bevoegde federale overheid' overleg dienen te plegen (a) voor iedere maatregel op het gebied van het energiebeleid, buiten de bevoegdheden opgesomd in SI, VII, en (b) over de grote lijnen van het nationaal energiebeleid. Hieruit kan worden afgeleid dat de BWHI expliciet melding maakt van 'de bevoegde federale overheid' en bijgevolg is volgens bepaalde rechtsleer de uitgestrektheid van de federale bevoegdheid inzake energie moeilijk vatbaar voor discussie. ${ }^{15}$ Uit een verdere lezing van de BWHI kan bovendien worden vastgesteld dat deze woordkeuze van de bijzondere wetgever ook heel bewust is geweest aangezien artikel 6, §3 bis van de BWHI melding maakt van een overleg tussen de betrokken regeringen en 'de betrokken federale overheid'. Volgens diezelfde rechtsleer bestaat er een wezenlijk verschil tussen een 'betrokken' en een 'bevoegde' federale overheid.

Op basis van ondermeer van het voorgaande is bepaalde rechtsleer, die door de auteurs wordt bijgetreden, van oordeel dat de gewesten enkel en alleen bevoegd zijn voor de gewestelijke aspecten van het energiebeleid. Daarentegen is de federale overheid bevoegd voor alle niet-gewestelijke aspecten van het energiebeleid en de expliciet vermelde bevoegdheden die wegens hun technische en economische ondeelbaarheid een gelijke behandeling op nationaal vlak vereisen. ${ }^{16}$ Hieruit kan worden afgeleid dat de BWHI niet in een limitatieve opsomming van de federale bevoegdheden met betrekking tot het energiebeleid voorziet. ${ }^{17}$

Los hiervan verdient het de voorkeur dat de bijzondere wetgever bij een volgende staatshervorming de bevoegdheidsverdeling tussen de federale en gewestelijke overheden met betrekking tot het energiebeleid verder verduidelijkt. Tevens is het aan te raden dat de bijzondere wetgever - met het oog op een betere afstemming tussen de regelgeving en de praktijk in de energiesector - in het artikel 6, SI, VII, eerste lid, a) van de BWHI, de huidige 70.000 volt-grens zou verlagen naar 30.000 volt.

I5. T. Vanden Borre, 'De federale ombudsdienst voor elektriciteit en gas: naar een nieuw artikel 27', in T. Vanden Borre (ed.), l.c., p. 145

I6. Ibid., p. I43-I45 en C. Vanderveeren, 'Regulators in a Federal Regime: the Belgian Case', l.c., p. 68-70.

I7. T. Vanden Borre, 'De federale ombudsdienst voor elektriciteit en gas: naar een nieuw artikel 27', in T. Vanden Borre (ed.), l.c., p. I44. 
Hierdoor zullen de gewesten onder meer bevoegd worden voor de distributie en het plaatselijke vervoer van elektriciteit via netten waarvan de nominale spanning lager is dan of gelijk is aan 30.000 volt.

De federale overheid is op basis van het artikel 6, §I, VII, tweede lid, d) van de BWHI als enige bevoegd voor de tarifaire maatregelen in het kader van het energiebeleid, en bijgevolg ook voor de distributienettarieven voor elektriciteit en gas van de diverse distributienetbeheerders. De gewestelijke overheden zijn daarentegen bevoegd voor alle maatregelen die betrekking hebben op distributienetbeheerders (onder andere kwaliteitsbewaking, structuur, organisatie, investeringsplannen, openbare dienstverplichtingen die aan hen worden opgelegd, etc.). Deze maatregelen hebben vaak tarifaire implicaties. Omwille van de logische samenhang en met het oog op een coherent energiebeleid zou de bijzondere wetgever bij voorkeur de federale bevoegdheden in het kader van de distributienettarieven elektriciteit en gas overdragen aan de gewestelijke overheden.

Momenteel kent men in België op basis van de hierboven vermelde bevoegdheidsverdeling vier verschillende systemen aan groenestroomcertificaten (zie ook hierna) die de productie van elektriciteit opgewekt door hernieuwbare energiebronnen bevorderen. Al zeer geruime tijd zijn er onderhandelingen lopende tussen de federale overheid en de gewesten, alsook tussen de diverse gewesten om de uitwisselbaarheid van groenestroomcertificaten mogelijk te maken. Om de coherentie van het beleid te bevorderen zijn de auteurs van oordeel dat de federale overheid en de gewesten zo spoedig mogelijk een samenwerkingsakkoord dienen te sluiten. Dit akkoord dient te voorzien in een vlotte uitwisselbaarheid van de groenestroomcertificaten, alsook een kostenefficiënte verdeling van de ambitieuze hernieuwbare energiedoelstelling van $13 \%$ voor België. ${ }^{18}$

Ten slotte dient de bijzondere wetgever te voorzien in een aantal tekstuele wijzigingen en verduidelijkingen met betrekking tot de termen 'openbare gasdistributie', 'nieuwe energiebronnen', 'nationaal uitrustingsprogramma in de elektriciteitssector' en 'productie van energie' die worden vermeld in het artikel 6, §I, VII van de BWHI.

Aangezien zowel het federale als het gewestelijke niveau bevoegdheden hebben in het kader van het energiebeleid heeft men op beide niveaus regulatoren opgericht voor de elektriciteits- en gasmarkten waarvan de bevoegdheden werden afgebakend op basis van de bevoegdheidsverdeling van de BWHI. Dit heeft geleid tot de oprichting van 4 regulatoren: op federaal niveau is dit de Commissie voor de Regu-

I8. Richtlijn 2009/28/EG van het Europees Parlement en de Raad van 23 april 2009 ter bevordering van het gebruik van energie uit hernieuwbare bronnen en houdende wijziging en intrekking van Richtlijn 200I/77/EG en Richtlijn 2003/30/EG, PB nr. LI40, 5 juni 2009. 
lering van de Elektriciteit en het Gas (afgekort 'CREG'); ${ }^{19}$ in het Brussels Hoofdstedelijk Gewest de reguleringscommissie voor energie in het Brussels Hoofdstedelijk Gewest, (afgekort 'BRUGEL'); ${ }^{20}$ in het Waalse Gewest de Commission Wallonne de Régulation pour l'Énergie (afgekort 'CWaPE') ${ }^{2 \mathrm{I}}$ en in het Vlaamse Gewest de Vlaamse Reguleringsinstantie voor de Elektriciteits- en Gasmarkt (afgekort 'VREG'). ${ }^{22}$

In het volgende onderdeel van deze bijdrage zal in eerste instantie worden stilgestaan bij de federale regulator CREG.

\section{Commissie voor de Regulering van de Elektriciteit en het Gas (CREG)}

\section{I Algemeen}

Tot omzetting van de eerste Elektriciteitrichtlijn $96 / 92 / \mathrm{EG}^{23}$ heeft de federale overheid de Wet van 29 april 1999 betreffende de organisatie van de elektriciteitsmarkt (hierna: 'Elektriciteitswet') ${ }^{24}$ afgekondigd. De belangrijkste doelstelling van de eerste Elektriciteitsrichtlijn is de geleidelijke openstelling van de elektriciteitssector in Europa voor de mededinging waarbij de zogenoemde 'in aanmerking komende afnemers' in de mogelijkheid worden gesteld om leveringscontracten af te sluiten met de leveranciers van hun keuze. Daarnaast beoogt de eerste Elektriciteitsrichtlijn een onafhankelijk beheer van het transmissienet, de vrijheid van vestiging voor de bouw van nieuwe productie-installaties, de vrije toegang tot het net, een sterkere regulering van de elektriciteitsmarkt, en de mogelijkheid voor de lidstaten om openbare dienstverplichtingen op te leggen aan de ondernemingen van de elektriciteitssector.

Naast deze doelstellingen voorzag de eerste Elektriciteitsrichtlijn dat de lidstaten een onafhankelijke bevoegde instantie dienden aan te wijzen om geschillen te beslechten met betrekking tot de toegang tot het net of aankoop van elektriciteit. De federale wetgever heeft hieraan gevolg gegeven door in artikel 23 van de Elektriciteitswet te voorzien in de oprichting van de Commissie voor de Regulering van

I9. Artikel 23 e.v. van de Wet van 29 april 1999 betreffende de organisatie van de elektriciteitsmarkt, B.S. II mei I 999 en artikel I5/I4 e.v. van de Wet van I2 april I965 betreffende het vervoer van gasachtige produkten en andere door middel van leidingen, B.S. 7 mei Ig6 $_{5}$ en www.creg.be.

20. Artikel zobis e.v. van de Ordonnantie van ig juli 200I betreffende de organisatie van de elektriciteitsmarkt in het Brussels Hoofdstedelijk Gewest, en www.brugel.be.

2I. Artikel 43 e.v. van het Decreet van I2 april 200 i betreffende de organisatie van de gewestelijke elektriciteitsmarkt, B.S. I mei 200 I en artikel 36 e.v. van het Decreet van I9 december 2002 betreffende de organisatie van de gewestelijke gasmarkt, B.S. II februari 2003, en www.cwape.be.

22. Decreet van 30 april 2004 tot oprichting van het publiekrechtelijk vormgegeven extern verzelfstandigd agentschap Vlaamse Reguleringsinstantie voor de Elektriciteits- en Gasmarkt, B.S. 27 mei 2004, en www.vreg.be.

23. Richtlijn 96/92/EG van het Europees Parlement en de Raad van I9 december I996 betreffende gemeenschappelijke regels voor de interne markt voor elektriciteit, PB nr. L 027 van 30 januari I997 (hierna: 'de eerste Elektriciteitsrichtlijn').

24. B.S. II mei I999. 
de Elektriciteit (afgekort de 'CRE') als autonoom organisme met rechtspersoonlijkheid. Zij had haar zetel in het administratief arrondissement Brussel-Hoofdstad. Hoewel volgens de Elektriciteitswet de CRE enkel bevoegd is voor de elektriciteitsmarkt heeft het artikel I5 van de wet van 29 april 1999 betreffende de organisatie van de gasmarkt en het fiscaal statuut van de elektriciteitsproducenten ${ }^{25}$ de CRE ook bevoegd gemaakt voor de gasmarkt. Bijgevolg kreeg de CRE als nieuwe benaming de Commissie voor de Regulering van de Elektriciteit en het Gas, ${ }^{26}$ of afgekort 'CREG'.

Zoals in verscheidene andere EU-lidstaten en parallel met andere marktsectoren die gradueel voor de mededinging werden opengesteld, heeft de omzetting van de vrijmakingsrichtlijnen in België op federaal niveau dus geleid tot de oprichting van een nieuwe regulerende instantie voor de elektriciteits- en gasmarkt. Volgens de artikelen 23 van de Elektriciteitswet en I5/I4 van de Gaswet $^{27}$ is de CREG in het algemeen belast met een raadgevende taak inzake de organisatie en de werking van de elektriciteits- en gasmarkt, enerzijds, en met een taak van toezicht en controle op de toepassing van de betreffende wetten en reglementen, anderzijds.

\subsection{Algemene bevoegdheden van de CREG}

De concrete invulling van deze algemene taken van de CREG zijn verder uitgewerkt in de artikelen 23, §2 van de Elektriciteitswet en I5/I4, §2 van de Gaswet en hebben onder meer betrekking op het brengen van gemotiveerde adviezen en voorstellen, het verrichten van onderzoeken en studies in verband met de werking van de elektriciteits- en gasmarkt, toezicht houden op de transparantie en de mededinging in de elektriciteits- en gasmarkt, het beoordelen van de objectief verantwoorde verhouding tussen de prijzen en de kosten van een bedrijf, het inrichten van een arbitrage- en bemiddelingsdienst, het uitbrengen van advies over de prospectieve studie betreffende de elektriciteitsbevoorrading en de prospectieve studie betreffende de gasbevoorrading, het uitoefenen van controle op de netbeheerder, het controleren en evalueren van de uitvoering van de openbare dienstverplichtingen, het uitbrengen van advies over het ontwikkelingsplan en het uitoefenen van toezicht op de uitvoering van dit plan, het goedkeuren van tarieven, het erop toezien dat de met name technische en tarifaire toestand van de elektriciteits- en gassector alsook de evolutie van deze sector het algemeen belang beogen en kaderen in het algemeen energiebeleid, het toezien op de essentiële belangen van de consument en de op de correcte toepassing van de openbare dienstverplichtingen door de betrokken ondernemingen, enzovoort.

Bovendien kan de CREG op eigen initiatief voorstellen doen in de gevallen waarin de Elektriciteits- of Gaswet of hun uitvoeringsbesluiten om haar advies vereisen.

\footnotetext{
25. B.S. II mei I999.

26. www.creg.be.

27. Wet van I2 april $1_{96} 65$ betreffende het vervoer van gasachtige produkten en andere door middel van leidingen, B.S. 7 mei rg65 $_{5}$ (hierna: 'Gaswet').
} 
De CREG zal haar adviezen en voorstellen uitbrengen binnen de veertig kalenderdagen nadat het verzoek werd ingediend, tenzij de bevoegde Minister een langere termijn voorstelt. Daarentegen kan de bevoegde Minister een kortere termijn bepalen voor de adviezen in het kader van het reciprociteitsbeginsel, of indien beschermingsmaatregelen dienen te worden genomen omwille van een plotse crisis op de energiemarkten of wanneer de fysieke veiligheid van personen, de veiligheid of betrouwbaarheid van uitrusting of installaties of de integriteit van het transmissienet wordt bedreigd. Tevens kan de CREG in de uitvoering van welbepaalde taken die aan haar zijn opgedragen de bijstand vorderen van de Algemene Directie Energie en de Administratie Directie Controle en Bemiddeling van de Federale Overheidsdienst Economie, KMO, Middenstand en Energie. ${ }^{28}$

\subsection{Bijzondere bevoegdheden van de CREG inzake anticompetitief gedrag, oneerlijke handelspraktijken en/of monitoring van de prijzen}

In 2008 heeft de federale wetgever door de afkondiging van de nieuwe artikelen

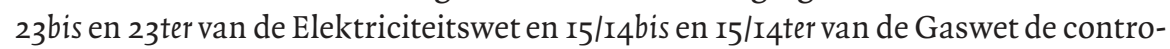
lerende en toezichthoudende taken van de CREG uitgebreid. ${ }^{29}$ Volgens de memorie van toelichting voorzien deze artikelen dat de CREG voortaan elke vorm van anticompetitief gedrag en/of oneerlijke handelspraktijken, die een invloed kan hebben op de goede werking van de elektriciteits- en/of gasmarkt, kan opsporen. Bovendien wordt aan de CREG de bevoegdheid verleend om voortaan alle componenten van de energieprijs te monitoren en dus niet meer alleen de gereguleerde tarieven.

Op grond van artikel 23bis van de Elektriciteitswet ziet de CREG er op toe dat elk elektriciteitsbedrijf die elektriciteit levert aan in België gevestigde afnemers, zich onthoudt, afzonderlijk of in overleg met meerdere andere elektriciteitsbedrijven van elk anticompetitief gedrag of elke vorm van oneerlijke handelspraktijken die een weerslag hebben of zouden hebben op een goed werkende elektriciteitsmarkt in België. Indien de CREG tijdens de uitoefening van deze taak anticompetitief gedrag of oneerlijke handelspraktijken zou vaststellen maakt zij op eigen initiatief hiervan een rapport over aan de bevoegde minister. In dit rapport maakt de CREG melding van haar bevindingen en desgevallend van elke maatregel waarvan zij het nodig acht dat deze door haar of door elke andere bevoegde overheid dient te worden getroffen om het anticompetitief gedrag of de oneerlijke handelspraktijken te verhelpen. Tevens maakt de CREG de veronderstelde inbreuken, het rapport en de noodzakelijk vertrouwelijke informatie over aan de Raad voor de Mededinging.

Daarnaast kan de koning, op voorstel van de CREG, bij een besluit dat wordt vastgesteld na overleg in de Ministerraad, dringende maatregelen voorzien die de CREG kan toepassen indien zij oneerlijke handelspraktijken vaststelt. Artikel 23bis van de

28. Zie artikel 23, $\$ 4$ van de Elektriciteitswet en artikel 20, $6^{\circ}$ van de Wet van I juni 2005.

29. Wet van 8 juni 2008 houdende diverse bepalingen, B.S. I6 juni 2008 en in het bijzonder de artikelen $85-92$. 
Elektriciteitswet voorziet bovendien dat de CREG adviezen kan formuleren en alle maatregelen voorstellen die de goede werking en transparantie van de markt verhogen. Deze maatregelen kunnen enkel van toepassing zijn op elektriciteitsbedrijven die actief zijn in België. Wat de aardgasmarkt betreft heeft de CREG op grond van artikel I5/I4bis van de Gaswet een volledig gelijklopende bevoegdheid om elk anticompetitief gedrag of elke vorm van oneerlijke handelspraktijken van aardgasondernemingen die aardgas leveren aan in België gevestigde afnemers aan te pakken.

Tevens voorzien de artikelen 23ter van de Elektriciteitswet en artikel I5/I4ter van de Gaswet in een controle door de CREG op de prijzen van een elektriciteitsbedrijf, respectievelijk aardgasonderneming. De prijzen van dergelijk bedrijf dienen op een objectief verantwoorde wijze in verhouding te staan tot de kosten van het desbetreffende bedrijf. Deze verhouding zal de CREG beoordelen door ondermeer de kosten en de prijzen van dergelijk bedrijf te vergelijken met de kosten en de prijzen van vergelijkbare bedrijven, indien mogelijk ook op internationaal niveau. Op grond van paragraaf 2 van de artikelen 23 ter van de Elektriciteitswet en artikel I5/I4ter van de Gaswet wordt misbruik van machtspositie vermoed als een elektriciteitsbedrijf, respectievelijk aardgasonderneming, een verbonden onderneming is die discriminatoire prijzen en/of voorwaarden aanbiedt aan niet-verbonden ondernemingen.

Indien de CREG zou vaststellen dat er geen objectief verantwoorde verhouding bestaat tussen de kosten en de prijzen van een dergelijk bedrijf, maakt ze op eigen initiatief aan de minister bevoegd voor energie een rapport over. In dit rapport formuleert de CREG haar bevindingen en beveelt zij maatregelen aan. De CREG maakt tevens de veronderstelde inbreuken, het rapport en de noodzakelijk vertrouwelijke informatie over aan de Raad voor de Mededinging. Bovendien kan de Koning, op voorstel van de CREG bij een besluit dat wordt vastgesteld na overleg in de ministerraad, dringende maatregelen voorzien die de CREG kan toepassen bij de vaststelling van discriminatoire prijzen en/of voorwaarden. Tenslotte bepaalt het laatste lid van paragraaf 3 van de artikelen 23ter van de Elektriciteitswet en artikel I5/I4ter van de Gaswet dat de CREG met betrekking tot prijzen adviezen kan formuleren en elke maatregel kan voorstellen ten aanzien van alle elektriciteitsbedrijven, respectievelijk aardgasondernemingen, actief in België.

Opdat de CREG deze bijkomende bevoegdheden daadwerkelijk zal kunnen uitoefenen, voorzien de artikelen 26, §I bis van de Elektriciteitswet, en I5/I6, §Ibis van de Gaswet, in ruimere onderzoeksbevoegdheden voor de CREG. Op basis hiervan zal de CREG bij de uitoefening van haar nieuwe bevoegdheden voortaan over de volgende onderzoeksbevoegdheden beschikken:

a) van de elektriciteitsbedrijven, respectievelijk aardgasondernemingen, elke inlichting verkrijgen, onder welke vorm ook, over materies die tot haar bevoegdheid en haar opdracht behoren binnen de dertig dagen na haar verzoek hieromtrent;

b) van deze bedrijven verslagen verkrijgen over hun werkzaamheden of bepaalde aspecten ervan; 
c) de informatie bepalen die haar regelmatig dient te worden meegedeeld en de periodiciteit waarmee deze informatie aan haar dient te worden overgezonden en

d) bij weigering van het toezenden van de gevraagde informatie binnen de dertig dagen overgaan tot het ter plaatse kennisnemen van alle hoger bedoelde inlichtingen en documenten die nodig zijn voor de uitvoering van de opdrachten die haar zijn toegewezen en deze desgevallend kopiëren.

Uit het voorgaande kan worden afgeleid dat de CREG over uitgebreide bevoegdheden beschikt om anticompetitief gedrag en oneerlijke handelspraktijken vast te stellen, alsook te controleren of er een objectieve verhouding bestaat tussen de prijzen van een elektriciteitsbedrijf, of een aardgasonderneming, en de kosten van dit bedrijf waarna de CREG haar analyse zal rapporteren aan de minister bevoegd voor energie en de Raad voor de Mededinging. In dit rapport kan de CREG desgevallend één of meerdere maatregelen suggereren die dergelijke praktijken verhelpen. Vervolgens kan de minister en/of de Raad voor de Mededinging in navolging van het rapport al dan niet bepaalde maatregelen treffen.

Het feit dat de minister en niet de CREG over de bevoegdheid zal beschikken om desgevallend welbepaalde maatregelen te treffen is volgens de auteurs enigszins opmerkelijk. Het is onduidelijk waarom de federale wetgever ervoor geopteerd heeft om dergelijke beslissingsbevoegdheid te leggen bij politieke instanties en niet bij de regulator die ons inziens als onafhankelijke instantie het meest aangewezen is om dergelijke beslissingen te treffen. Bovendien lijkt dit niet meteen in de lijn te liggen met het recent goedgekeurde derde pakket aan energiewetgeving op Europees niveau. In dit pakket aan nieuwe energiewetgeving wordt voorzien dat de lidstaten één onafhankelijk regulerende instantie dienen aan te wijzen op nationaal niveau die bij het verrichten van haar reguleringstaken geen directe of instructies verlangen of ontvangen van regeringen of ander publieke of particuliere entiteiten. Daarnaast dienen de lidstaten erover te waken dat de regulerende instanties onafhankelijk van enig politiek orgaan zelfstandig besluiten kunnen nemen. ${ }^{30}$

\subsection{Bijzondere bevoegdheden van de CREG tot opsporen en vaststellen van inbreuken}

Met de Programmawet van 22 december $2008^{3 \mathrm{I}}$ heeft de federale wetgever ervoor geopteerd om de bevoegdheden van de CREG bijkomend te versterken door aan de leden van het directiecomité en het personeel de hoedanigheid van officieren van gerechtelijke politie toe te kennen. Voordien was dergelijke hoedanigheid van officieren van gerechtelijke politie enkel voorbehouden voor de door de Koning aan te wijzen ambtenaren van de Federale Overheidsdienst Economie, KMO, Middenstand

30. Zie hierna.

3I. B.S. I9 december 2008 en zie in het bijzonder de artikelen 67 en 68. 
en Energie. Deze versterking van de bevoegdheden van de CREG is opgenomen in het artikel zobis van de Elektriciteitswet en artikel I8 van de Gaswet.

Bovendien voorzien de wijzigingen dat de processen-verbaal, die door de aangestelde van de CREG en van de ambtenaren van de federale overheidsdienst Economie, KMO, Middenstand en Energie aangesteld door de Koning om de inbreuken op de Elektriciteitswet en haar uitvoeringsbesluiten op te sporen en vast te stellen, een bijzondere bewijswaarde hebben en bewijskracht hebben tot bewijs van het tegendeel. In tegenstelling tot de ambtenaren wordt de hoedanigheid van officieren van gerechtelijke politie in hoofde van de leden van de CREG beperkt aangezien ze deze hoedanigheid enkel zullen kunnen uitoefenen om inbreuken van anticompetitief gedrag, oneerlijke handelspraktijken en/of niet correcte tarieven vast te stellen.

De leden van de CREG die over de hoedanigheid van officieren van gerechtelijke politie beschikken kunnen:

a) gebouwen, werkplaatsen en hun aanhorigheden tijdens de openings- of werkuren betreden, wanneer zulks voor de uitoefening van hun opdracht noodzakelijk is;

b) alle dienstige vaststellingen doen, zich documenten, stukken, boeken en voorwerpen die bij de opsporing en vaststellingen van inbreuken nodig zijn, doen vertonen en die in beslag nemen;

c) alle inlichtingen verzamelen en alle geschreven of mondelinge verklaringen of getuigenissen afnemen;

d) bijstand verlenen in het kader van de uitvoering van de beslissingen van de CREG.

Indien de hierboven vermelde daden de kenmerken hebben van een huiszoeking dan mogen deze enkel met toepassing van de artikelen 87 tot 90 van het Wetboek van Stafvordering ${ }^{32}$ worden uitgevoerd en bijgevolg zal een tussenkomst van een onderzoeksrechter noodzakelijk zijn. Dewijze waarop de leden van de CREG hun opdracht van officier van gerechtelijke politie zullen uitoefenen wordt nader bepaald bij een koninklijk besluit. 33

\subsection{Samenstelling van de CREG}

Op basis van artikel 24 van de Elektriciteitswet en artikel I5/I5 van de Gaswet zijn binnen de CREG, twee organen actief, het directiecomité en de algemene raad. 34

32. B.S. 27 november 1808 .

33. Dit koninklijk besluit werd op het moment van het schrijven van deze bijdrage nog niet afgekondigd.

34. Noteer dat de CREG een huishoudelijk reglement heeft dat door het directiecomité en de algemene raad werd opgesteld, zie het koninklijk besluit van Io oktober 200 I tot goedkeuring van het huishoudelijk reglement van de commissie voor de regulering van de elektriciteit en het gas, B.S. I6 oktober 200 . 
Het directiecomité staat in voor het operationeel bestuur van de CREG en stelt alle handelingen die nodig of dienstig zijn voor de uitvoering van de aan de CREG toegekende opdrachten op grond van artikel 23, § 2 van de Elektriciteitswet en artikel I5/I4, §2 van de Gaswet. Dit directiecomité beraadslaagt 'volgens de gewone regels van beraadslagende vergaderingen'. Volgens de Memorie van Toelichting betreft het hier een verwijzing naar artikel 67 van de gecoördineerde wetten op de handelsvennootschappen. Daaruit volgt dat het directiecomité slechts beslissingen kan nemen indien de meerderheid van zijn leden aanwezig is, en dat beslissingen worden genomen met meerderheid van de uitgebrachte stemmen.

Het directiecomité is samengesteld uit een voorzitter en drie andere leden: een administratieve directie, een directie voor de technische werking van de elektriciteits- en gasmarkt en een directie voor de controle op de prijzen en de rekeningen. Het directiecomité wordt aangeduid voor een hernieuwbare termijn van 6 jaar. Hierbij kan erop worden gewezen dat de wetgever heeft nagelaten om de nieuwe bevoegdheden van de CREG - om anticompetitief gedrag en oneerlijke handelspraktijken vast te stellen, alsook te controleren of er een objectieve verhouding bestaat tussen de prijzen van een elektriciteitsbedrijf, of een aardgasonderneming, en de kosten van dit bedrijf - toe te wijzen aan één van de hierboven vermelde directies.

Het directiecomité staat onder het toezicht van de algemene raad. Deze algemene raad is samengesteld uit vertegenwoordigers van de federale en gewestelijke regeringen, werkgevers-, werknemers- en middenstandsorganisaties en milieuverenigingen, producenten, de netbeheerder, distributienetbeheerders, tussenpersonen en leveranciers en verbruikers. De precieze samenstelling en werking van de algemene raad is uitgewerkt in het koninklijk besluit van 3 mei I999 betreffende de samenstelling en de werking van de algemene raad van de Commissie voor de Regulering van de Elektriciteit en het Gas. 35

Op grond van artikel 24, \$3, lid 3 van de Elektriciteitswet kan de algemene raad ten allen tijde het directiecomité om advies vragen. Daarnaast heeft het zelf de volgende taken: (a) op eigen initiatief of op verzoek van de bevoegde Minister de richtsnoeren bepalen voor de toepassing van de Elektriciteits- en de Gaswet en de uitvoeringsbesluiten ervan; (b) binnen de 40 dagen na ontvangst van het verzoek vanwege het directiecomité een advies formuleren betreffende elke kwestie die hem door het directiecomité wordt voorgelegd, en (c) een discussieforum zijn over de doelstellingen en strategieën van het energiebeleid.

De CREG dient jaarlijks voor I mei van het jaar volgend op het betrokken boekjaar aan de bevoegde Minister een verslag over te maken waarin (a) de uitvoering van haar opdrachten; (b) de staat van haar werkingskosten en de wijze waarop zij gedekt zijn, met inbegrip van een overzicht van activa/passiva en (c) de evolutie van de

35. B.S. I5 juni 1999, Noteer dat de samenstelling van de algemene raad meermaals werd gewijzigd zowel in de Elektriciteitswet als in het uitvoeringsbesluit. 
elektriciteits- en gasmarkt worden behandeld. Dit jaarverslag wordt door de minister aan de federale wetgevende kamer en aan de gewestregeringen overgemaakt.

Jaarlijks dient het directiecomité voor 30 oktober een ontwerpbegroting en beleidsplan voor het daarop volgende jaar ter goedkeuring voor te leggen aan de ministerraad. Daarnaast dient de bevoegde minister op grond van artikel 23, \$3 van de Elektriciteitswet jaarlijks aan de ministerraad een rapport voor te leggen met een vergelijkende tabel van de doelstellingen zoals opgenomen in het beleidsplan en de realisatie ervan tijdens het desbetreffende jaar. Indien uit deze vergelijking zou worden afgeleid dat de vooropgestelde doelstellingen niet werden gehaald dan zal het directiecomité dit moeten verantwoorden. Als de door het directiecomité verleende verantwoording onvoldoende zou zijn dan zal de ministerraad, op voorstel van de minister, aan het directiecomité, hetzij uitvoeringsrichtlijnen met het oog op het bereiken van de doelstellingen vervat in het goedgekeurde beleidsplan, hetzij concrete beleidsrichtlijnen met het oog op het herformuleren of bijsturen van de doelstellingen vervat in het goedgekeurde beleidsplan. Deze versterkte controle door de federale regering op de CREG werd ingevoerd door de wet van 20 juli 2006 houdende diverse bepalingen, $3^{6}$ maar zoals hierboven werd vermeld is dit volledig in strijd met de Europese visie waarbij men duidelijk de kaart trekt voor een regulator die onafhankelijk is van enig politiek orgaan. 37

\subsection{Bemiddelings- en arbitragedienst}

Op grond van artikel 28 van de Elektriciteitswet en artikel I5/I7 van de Gaswet dient de CREG voor geschillen betreffende de toepassing van het technisch reglement en de aansluitingstarieven een bemiddelings- en arbitragedienst op te richten en het secretariaat ervan waar te nemen. De bemiddelaars en arbiters voor deze bemiddelings- en arbitragedienst worden aangewezen op basis van een door de minister vast te stellen lijst. Op grond van artikel 28 van de Elektriciteitswet kunnen de leden van de organen en de personeelsleden van de CREG niet als arbiters worden aangewezen.

Het reglement voor deze bemiddelings- en arbitragedienst dient te worden vastgesteld door de Koning op voorstel van de CREG. Hieraan werd gevolg gegeven door de afkondiging van het Koninklijk Besluit van I7 december 2002 houdende vaststelling van het reglement van de bemiddelings- en arbitragedienst van de Commissie voor de Regulering van de Elektriciteit en het Gas. ${ }^{38}$ Dit besluit is tot op heden nog niet in werking getreden.

36. B.S. 28 juli 2006 in het bijzonder de artikelen 128 tot en met ${ }_{13} 8$.

37. Zie hiervoor.

38. B.S. 8 januari 2003. 


\section{Gewestelijke regulatoren: VREG, CWaPE en BRUGEL}

\section{I Inleiding}

In uitvoering van de eerste Elektriciteitsrichtlijn, de eerste Aardgasrichtlijn, artikel 23 van de Tweede Elektriciteitsrichtlijn, 39 artikel 25 van de Tweede Aardgasrichtlijn $4^{\circ}$ en op basis van de onderscheiden gewestelijke bevoegdheden in het kader van het energiebeleid heeft elk Gewest een gewestelijke 'regelgevende instantie' of, 'regulator', opgericht voor de elektriciteits- en gasmarkt op haar grondgebied. Er zijn er drie: de VREG, de CWaPE en BRUGEL.

De VREG is de Vlaamse Reguleringsinstantie voor de Elektriciteits- en Gasmarkt. Zij werd opgericht middels artikel 27 van het Vlaamse Elektriciteitsdecreet. ${ }^{4 \mathrm{r}}$ Dit artikel voorzag in de oprichting van een 'reguleringsinstantie', initieel belast met de regulering en de controle van de Vlaamse elektriciteitsmarkt. Na de goedkeuring van het Vlaamse Aardgasdecreet ${ }^{42}$ werd de VREG ook bevoegd voor de regulering en de controle van de Vlaamse aardgasmarkt. In 2004 werd de organisatie en de werking van de VREG substantieel gewijzigd door het decreet van 30 april 2004 tot oprichting van het publiekrechtelijk vormgegeven extern verzelfstandigd agentschap Vlaamse Reguleringsinstantie voor de Elektriciteits- en Gasmarkt. ${ }^{3}$ Dit oprichtingsdecreet verving vanaf dan de bepalingen van het Elektriciteitsdecreet en het Aardgasdecreet voor de oprichting en de taken van de VREG.

Op 8 mei 2009 werd het nieuwe Vlaamse Energiedecreet 44 uitgevaardigd. Dit decreet is op heden nog niet in werking. De Vlaamse Regering bepaalt de datum waarop de verschillende bepalingen in werking zullen treden. Het Vlaamse Energiedecreet coördineert de verschillende Vlaamse decreten inzake energie. Het heft het Vlaamse Elektriciteitsdecreet en het Vlaamse Aardgasdecreet op en vervangt ze. Ook het Oprichtingsdecreet wordt opgeheven en vervangen. De benaming van de VREG wordt daarbij dan vereenvoudigd tot 'Vlaamse Regulator van de Elektriciteitsen Gasmarkt'. 45

39. Richtlijn 2003/54/EG van 26 juni 2003 betreffende de gemeenschappelijke regels voor de interne markt voor elektriciteit en houdende intrekking van Richtlijn 96/92/EG.

40. Richtlijn 2003/55/EG van 26 juni 2003 betreffende de gemeenschappelijke regels voor de interne markt voor gas en houdende intrekking van Richtlijn 98/30/EG.

4I. Decreet van I7 juli 2000 houdende de organisatie van de elektriciteitsmarkt, B.S. 22 september 2000 (hierna het Vlaamse Elektriciteitsdecreet), dat meermaals werd gewijzigd.

42. Decreet van 6 juli 200 r houdende de organisatie van de gasmarkt, B.S. 3 oktober 200 (hierna het Vlaamse Aardgasdecreet), dat meermaals werd gewijzigd .

43. B.S. 27 mei 2004, (hierna het Oprichtingsdecreet) dat meermaals werd gewijzigd. Het Oprichtingsdecreet is in werking getreden op I april 2006 (zie artikel I van het Besluit van de Vlaamse Regering van 3I maart 2006 tot operationalisering van het beleidsdomein Leefmilieu, Natuur en Energie, B.S. I9 mei 2006).

44. Decreet van 8 mei 2009 houdende algemene bepalingen betreffende het energiebeleid (hierna het Vlaamse Energiedecreet), B.S. 7 juli 2009

45. Artikel 3.I.I. van het Vlaamse Energiedecreet. 
De CWaPE is de Commission Wallonne pour l'Energie. Zij werd opgericht door het Waalse Elektriciteitsdecreet. ${ }^{46}$ Haar bevoegdheden waren initieel beperkt tot de regulering en de controle van de Waalse elektriciteitsmarkt. Na de inwerkingtreding van het Waalse Aardgasdecreet ${ }^{47}$ werden haar bevoegdheden uitgebreid tot de regulering en controle van de Waalse aardgasmarkt.

BRUGEL is de reguleringscommissie voor energie opgericht in het Brussels Hoofdstedelijk Gewest. De afkorting staat voor 'Brussel Gas Elektriciteit'. BRUGEL werd opgericht na invoeging door de Ordonnantie van I4 december 2006 van een nieuw hoofdstuk 6bis 'reguleringsautoriteit' in de Elektriciteitsordonnantie. ${ }^{48}$ Dit nieuwe hoofdstuk in de Elektriciteitsordonnantie geldt zowel voor de Brusselse elektriciteitsmarkt als de Brusselse gasmarkt. De Aardgasordonnantie 49 verwijst voor BRUGEL naar de bepalingen van de reguleringsautoriteit, zoals opgenomen in de Elektriciteitsordonnantie.

Vóór de oprichting van BRUGEL kende de Brusselse energiemarkt geen 'echte’ reguleringsautoriteit. ${ }^{\circ}$ De diensten van het Brussels Hoofdstedelijk Gewest (met name de Brusselse Hoofdstedelijke Regering en het Brussels Instituut voor Milieubeheer ('BIM') ${ }^{5 \mathrm{I}}$ ) namen tot dan de taken van de reguleringsautoriteit op zich.

\subsection{Vorm}

De VREG is een publiekrechtelijk vormgegeven extern verzelfstandigd agentschap ('EVA'), opgericht in de zin van artikel I3 van het Kaderdecreet Bestuurlijk

46. De artikelen 43 t.e.m. 50 van het Decreet van 12 april 200 r betreffende de organisatie van de gewestelijke elektriciteitsmarkt, B.S. I mei 200 I (hierna 'het Waalse Elektriciteitsdecreet'), dat meermaals werd gewijzigd.

47. De artikelen 36 en 36 bis van het Decreet van ig december 2002 betreffende de organisatie van de gewestelijke gasmarkt, B.S. II februari 2003 (hierna 'het Waalse Aardgasdecreet'), dat meermaals werd gewijzigd.

48. Ordonnantie van I4 december 2006 tot wijziging van de ordonnanties van ig juli 200 I en van I april 2004 betreffende de organisatie van de elektriciteitsmarkt en de gasmarkt in het Brussels Hoofdstedelijk Gewest en tot opheffing van de ordonnantie van II juli I99I met betrekking tot het recht op een minimumlevering van elektriciteit en de ordonnantie van II maart 1999 tot vaststelling van de maatregelen ter voorkoming van de schorsingen van de gaslevering voor huishoudelijk gebruik, op basis waarvan de artikelen zobis t.e.m. 3oocties werden ingevoegd in de Ordonnantie van I9 juli 200I betreffende de organisatie van de elektriciteitsmarkt in het Brussel Hoofdstedelijk Gewest, B.S. I7 november 200 I (hierna de Elektriciteitsordonnantie), dat meermaals werd gewijzigd.

49. Ordonnantie van I april 2004 betreffende de organisatie van de gasmarkt in het Brussels Hoofdstedelijk Gewest, betreffende wegenisretributies inzake gas en elektriciteit en houdende wijziging van de ordonnantie van I9 april 200 I betreffende de organisatie van de elektriciteitsmarkt in het Brussels Hoofdstedelijk Gewest, B.S. 26 april 2004 (hierna de Aardgasordonnantie), dat meermaals werd gewijzigd.

50. Ontwerp van ordonnantie betreffende de organisatie van elektriciteitsmarkt in het Brussels Hoofdstedelijk Gewest, Memorie van Toelichting, Parl. St. Br. H. R. 2000-oI, doc A-I92/I, 7-8.

5I. Waarvan de afkorting staat voor 'Institut Bruxellois pour la Gestion de l'Environnement - Brussels Instituut voor Milieubeheer'. IBGE-BIM is de overheidsdienst van het Brussels Hoofdstedelijk Gewest voor milieu- en energie. 
Beleid van I8 juli 200352.53 De VREG heeft rechtspersoonlijkheid. Het Vlaamse Elektriciteitsdecreet, noch het Oprichtingsdecreet bepalen waar de VREG haar vestigingsplaats dient te hebben. Momenteel is zij gevestigd in Brussel. Het nieuwe Vlaamse Energiedecreet definieert de VREG uitdrukkelijk als een publiekrechtelijk vormgegeven EVA, opgericht in de zin van het Kaderdecreet Bestuurlijk Beleid. De Vlaamse Regering zal haar vestigingsplaats bepalen. 54

De CWaPE is een autonome instelling ('organisme autonome') met rechtspersoonlijkheid. Haar zetel is gelegen in het administratieve arrondissement van Namen. 55

BRUGEL is eveneens een publiekrechtelijke rechtspersoon. Zij heeft haar zetel in het Brussels Hoofdstedelijk Gewest..$^{6}$

\subsection{Samenstelling, bestuur en werking}

De samenstelling van de drie regulatoren is vrij gelijklopend. Het bestuur is telkens in handen van een groep bestuurders, aangesteld door de respectievelijke gewestregering. Eén van deze bestuurders wordt aangesteld als voorzitter en treedt op als vertegenwoordiger van de betreffende regulator.

De VREG heeft een 'Raad van Bestuur'. Zij is samengesteld uit minstens drie leden, waaronder de voorzitter en de gedelegeerd bestuurder. De leden worden aangeduid door de Vlaamse Regering. 57 Het Oprichtingsdecreet, noch het huishoudelijk reglement bepalen de termijn voor dewelke de Raad van Bestuur wordt aangeduid. Terzake gelden er wel strikte onverenigbaarheidsregels..$^{8}$ De Raad van Bestuur beschikt over de volheid van bestuursbevoegdheid en beslist in alle aangelegenheden waarvoor de VREG bevoegd is. Alle leden van de Raad van Bestuur zijn stemgerechtigd. ${ }^{59}$ Het Oprichtingsdecreet somt een achttal kerntaken van de Raad van Bestuur op. Het is decretaal verboden één of meer van deze kerntaken te delegeren aan personeelsleden van de VREG. ${ }^{60}$

52. B.S. 22 augustus 2003.

53. Artikel 4, SI van het Oprichtingsdecreet.

54. Artikel 3.I.I. van het Vlaamse Energiedecreet.

55. Artikel 43, §I van het Waalse Elektriciteitsdecreet.

56. Artikel 3obis, SI van de Elektriciteitsordonnantie.

57. Artikelen 8, SI en I2, SI van het Oprichtingsdecreet, uitgevoerd door het besluit van de Vlaamse Regering van 3I maart 2006 tot vaststelling van de Raad van Bestuur van het publiekrechtelijk vormgegeven extern verzelfstandigd agentschap Vlaamse Reguleringsinstantie voor de Elektriciteits- en Gasmarkt, B.S. I6 mei 2006. Zie ook de artikelen 3.I.5. en 3.I.9. van het Vlaamse Energiedecreet.

58. Artikel Io van het Oprichtingdecreet. Zie ook artikel 3.I.7. van het Vlaamse Energiedecreet.

59. Artikel 9 van het Oprichtingsdecreet. Zie ook artikel 3.I.6. van het Vlaamse Energiedecreet.

6o. Artikel II van het Oprichtingsdecreet. Vergeleken met het nieuwe artikel 3.I.8 van het Vlaamse Energiedecreet valt op dat het opstellen van de technische reglementen niet meer tot deze kerntaken behoort. Vanaf de inwerkingtreding van (dit deel van het) Vlaamse Energiedecreet, is het opstellen van de technische reglementen dan ook een operationele taak, die kadert in het dagelijks bestuur. 
In een huishoudelijk reglement wordt de werking van de Raad van Bestuur beschreven en worden de taken van dagelijks bestuur opgesomd. Het huishoudelijk reglement wordt opgesteld door de Raad van Bestuur en goedgekeurd door de Vlaamse Regering. ${ }^{6 \mathrm{r}} \mathrm{De}$ gedelegeerd bestuurder is belast met het dagelijks bestuur van de VREG. Hij wordt bijgestaan door een directieraad. Hij bereidt de beslissingen van de Raad van Bestuur voor, verstrekt aan de Raad van Bestuur alle inlichtingen en brengt alle voorstellen die voor de werking van de VREG nuttig of nodig zijn op de agenda. Daarnaast dient hij de beslissingen van de Raad van Bestuur uit te voeren. Hij vertegenwoordigt de VREG in alle gerechtelijke en buitengerechtelijke handelingen. Hij is tevens belast met de leiding van het personeel, aan wie hij, onder zijn verantwoordelijkheid, één of meer specifieke bevoegdheden kan delegeren. ${ }^{62}$

Het bestuur van de CWaPE is in handen van een 'comité de direction', bestaande uit een voorzitter en vijf directeuren. Zij worden benoemd door de Waalse Regering voor een periode van 5 jaar, eenmaal verlengbaar. Hun mandaat eindigt automatisch bij het bereiken van de leeftijd van $6_{5}$ jaar. Eventueel kan dit mandaat worden verlengd - voor maximaal één jaar - tot op het ogenblik waarop een opvolger kan worden benoemd. ${ }^{63}$ De huidige leden van het directiecomité van de CWaPE (op heden zijn er maar vier directeuren) werden aangeduid tot eind augustus 2009. Het statuut van de president en de directeuren van de CWaPE, de procedure tot aanstelling en de basisprincipes voor hun vergoeding, worden bepaald door de Waalse Regering. ${ }^{64}$

De voorzitter vertegenwoordigt de CWaPE. Hij zit het directiecomité voor. Zijn stem is doorslaggevend bij een gelijk aantal stemmen. Hij coördineert en overziet de handelingen van de directeuren. De voorzitter wordt bijgestaan door een secretarisgeneraal. Deze wordt aangesteld door het directiecomité. De secretaris-generaal staat het directiecomité bij, zonder beraadslagende stem. Hij stelt de processenverbaal van de vergaderingen van het directiecomité op. ${ }^{65}$

Elke directeur staat aan het hoofd van één van de directies van de $\mathrm{CWaPE}^{66}$ en is verantwoordelijk voor de goede werking ervan. Hij staat onder gezag van de voorzitter, aan wie hij rapporteert over de werking van zijn directie. Het directiecomité makkt binnen de zes maanden na de benoeming van de voorzitter een 'feuille de route' over aan de Waalse Regering waarin de doelstellingen van de CWaPE en de

6r. Artikel I4 van het Oprichtingsdecreet. Het huishoudelijk reglement werd goedgekeurd bij Ministerieel Besluit van 28 juli 2006 houdende het huishoudelijk reglement van de raad van bestuur van de Vlaamse Reguleringsinstantie voor de Elektriciteits- en de Gasmarkt, B.S. 9 augustus 2006. Zie ook artikel 3.I.I van het Vlaamse Energiedecreet.

62. Artikel I3 van het Oprichtingsdecreet. Zie ook de artikelen 3.I.9 en 3.I.Io van het Vlaamse Energiedecreet.

63. Artikel 45, §I van het Waalse Elektriciteitsdecreet.

64. Artikel 45, \$3 van het Waalse Elektriciteitsdecreet. Zie in dat verband het besluit van de Waalse Regering van I4 juni 200 r tot bepaling van de grondslag voor de bezoldiging van de voorzitter en bestuurders van het directiecomité van de Commission Wallonne pour l'Energie, B.S. 5 juli 200 .

65. Artikel 46, §ibis van het Waalse Elektriciteitsdecreet.

66. Artikel 46, SI van het Waalse Elektriciteitsdecreet. 
te ondernemen actiepunten staan beschreven. Het directiecomité bepaalt onder andere de rekruterings- en arbeidsvoorwaarden en stelt het personeel van de CWaPE aan. ${ }^{67}$ De onverenigbaarheidsregels worden bepaald door de Waalse Regering. ${ }^{68}$ Het huishoudelijk reglement wordt opgesteld door de CWaPE en goedgekeurd door de Waalse Regering. ${ }^{69}$ Ten slotte vermelden we nog dat de CWaPE onderworpen is aan de controle van het Rekenhof..$^{\circ}$

De werking van BRUGEL is in handen van een 'Raad van Bestuur'. Zij is samengesteld uit een voorzitter en vier bestuurders. Zij worden benoemd door de Regering van het Brussels Hoofdstedelijk Gewest voor een periode van vijf jaar. De voorwaarden voor hun benoeming en de afzetting, alsook hun statuut, worden eveneens bepaald door de Regering. ${ }^{71}$ Ook hier gelden bepaalde onverenigbaarheidsregels..$^{2}$ Het huishoudelijk reglement wordt opgesteld door BRUGEL en goedgekeurd door de Regering van het Brussels Hoofdstedelijk Gewest. ${ }^{73}$ BRUGEL is geen permanent orgaan, maar komt telkens bijeen als haar opdrachten dat vereisen. ${ }^{74}$ De voorzitter van de Raad van Bestuur vertegenwoordigt BRUGEL bij de nationale, internationale en Europese instanties, alsook in alle gerechtelijke en buitengerechtelijke handelingen. De voorzitter en de bestuurders 75 worden vergoed met zitpenningen. ${ }^{76}$

Daarnaast stelt de Elektriciteitsordonnantie dat de voorzitter, of een door de voorzitter aangewezen bestuurder, de vergaderingen van het BIM bijwoont met raadgevende stem, 'wanneer deze betrekking hebben op vragen betreffende energie'.77 De werking van BRUGEL komt ten laste van de begroting van het BIM.

Aangezien de taken van de regulator in het Brussels Hoofdstedelijk Gewest, vóór de aanduiding van BRUGEL, grotendeels werden verzorgd door het BIM, bevat de

67. Artikel 46, \$2 van het Waalse Elektriciteitsdecreet. Het personeel van de CWaPE wordt aangesteld middels arbeidsovereenkomsten. A contrario kan een personeelslid van de CWaPE niet statutair worden benoemd.

68. Zie, in uitvoering van een vroegere versie van het Waalse Elektriciteitsdecreet, het besluit van de Waalse Regering van I4 juni 200 I tot bepaling van de regels die toepasselijk zijn op de voorzitter en de bestuurders van het directiecomité van de Commission wallonne pour l'Energie inzake onverenigbaarheden van mandaten en belangenconflicten, B.S. 5 juli 200 I.

69. Artikel 44, SI van het Waalse Elektriciteitsdecreet. Zie in dat verband het besluit van de Waalse Regering van I2 februari 2009 tot goedkeuring van het huishoudelijk reglement van de Commission Wallonne pour l'Energie en tot opheffing van het besluit van de Waalse Regering van 27 maart 2003, B.S. I7 maart 2009.

70. Artikel 47ter, \$5 van het Waalse Elektriciteitsdecreet.

7I. Artikelen zoter en zoquinquies, SI van de Elektriciteitsordonnantie.

72. Artikel zoquinquies, \$2 van de Elektriciteitsordonnantie.

73. Artikel zosexies van de Elektriciteitsordonnantie.

74. Artikel zoquater van de Elektriciteitsordonnantie. Zie ook G. Block en L. Hage, 'Les grands axes de la réforme des marchés de l'électricité et du gaz en Région de Bruxelles-Capitale à la suite de l'ordonnance du I4 décembre 2006', J.T. $2007,630$.

75. Merkwaardig genoeg is er in deze bepaling sprake van drie bestuurders, terwijl artikel zoter van de Elektriciteitsordonnantie stelt dat 'de Commissie bestaat uit een voorzitter en vier bestuurders'.

76. Artikel zoquinquies, §6 van de Elektriciteitsordonnantie.

77. Artikel 3oquinquies, $\$ \$ 4-5$ van de Elektriciteitsordonnantie. 
Elektriciteitsordonnantie nog verscheidene verwijzingen naar het BIM, dat terzake een grote invloed uitoefent. Zo bepaalt de Elektriciteitsordonnantie dat rechtsvorderingen, als eiser en verweerder, worden ingesteld conform BRUGELs beslissing, in haar eigen naam, maar ten verzoeke van het BIM. Betekent dit dat BRUGEL terzake zelf geen beslissingsmacht heeft om een procedure op te starten of als verweerder in een procedure op te treden, aangezien dit altijd dient te gebeuren op verzoek van BIM? De Franse tekst stelt dat 'les actions judiciaires, en demandant comme en défendant, sont exercées conformément à la décision de [BRUGEL] et en son nom, 'poursuites et diligences' de l'Institut bruxellois pour la Gestion de l'Environnement' (eigen cursivering). Uit de samenlezing van de Nederlandse en de Franse tekst zou kunnen worden begrepen dat rechtszaken door BRUGEL in eigen naam en volgens haar beslissing worden gevoerd, maar telkens ten verzoeke en voor rekening van het BIM. BRUGEL is nochtans een publiekrechtelijke rechtspersoon, die persoonlijk en zelfstandig kan (en moet) optreden. Het is dan ook onduidelijk waarom gedingen 'poursuites et diligences' van BIM moeten worden gevoerd. Een en ander is wellicht te verklaren vanuit de idee dat BRUGEL, hoewel een publiekrechtelijke rechtspersoon, geen permanent orgaan is.

Verreweg de meeste doorwerking gaat evenwel uit van het systeem van de zogenoemde 'opdrachthouders'. Dit zijn - statutaire of contractuele - personeelsleden van het BIM, die, na het akkoord van de Brusselse Hoofdstedelijke Regering en BRUGEL, belast worden met een opdracht bij BRUGEL. Deze personeelsleden worden dus ter beschikking gesteld van BRUGEL voor het uitvoeren van één of meer opdrachten, die nominatim zijn opgesomd in de Elektriciteitsordonnantie. Zij voeren deze taken uit onder het hiërarchisch gezag van de Raad van Bestuur van BRUGEL. De administratieve en geldelijke behandeling van de dossiers blijven wel bij het BIM. Zij blijven ook onderworpen aan het personeelsstatuut van BIM. ${ }^{78}$ De achterliggende idee is dat de terbeschikkingstelling van personeelsleden van BIM aan BRUGEL, deze laatste in staat zal stellen om gebruik te maken van de door de dienst Leefmilieu Brussel opgedane ervaring en in de uitvoering van haar reguleringsopdrachten bijgestaan te worden door personeel dat steeds beter gespecialiseerd is in aangelegenheden die met de regulering van de energiemarkt hebben te maken. ${ }^{79} \mathrm{De}$ Elektriciteitsordonnantie verleent BRUGEL inderdaad niet de bevoegdheid om zelf personeel aan te werven.

De opdrachthouders bereiden, samen met de voorzitter van BRUGEL, de dossiers voor die worden behandeld tijdens de vergaderingen van de Raad van Bestuur van BRUGEL. Zij informeren daarbij de voorzitter over dringende beslissingen en voeren de voorbereidende werken uit die zijn voorzien in het huishoudelijk reglement. ${ }^{80}$

78. Artikel zoocties van de Elektriciteitsordonnantie.

79. M. Schurmans en W. Vandenberghe, 'Voornaamste ontwikkelingen in het gewestelijke energiebeleid en -recht in 2007-2008' in K. Deketelaere en B. Delvaux (eds.), Jaarboek Energierecht 2007, Antwerpen, Intersentia, 2008, 207.

8o. Artikel zoocties, SIo van de Elektriciteitsordonnantie. 
Het bovenstaande is - minstens - opmerkelijk te noemen. Men kan zich de vraag stellen in welke mate BRUGEL onafhankelijk kan werken van het BIM, dat een overheidsinstantie is. Vanuit de idee dat een regulator een onafhankelijke instantie is die over de marktwerking en de marktactoren dient te waken, is dit dan ook een merkwaardige vaststelling. De vraag stelt zich of de huidige opvatting van 'een regulator' in het Brussels Hoofdstedelijk Gewest de toets zal kunnen doorstaan die de EU - met het derde pakket energiemaatregelen, zie hierna - zal invoeren.

\subsection{Onder toezicht}

De drie gewestelijke regulatoren staan onder toezicht van hun respectieve gewestregering. Deze laat controle uitoefenen via twee door haar aangestelde regeringscommissarissen. Voor de CwaPE werd dit uitdrukkelijk opgenomen in het Waalse Elektriciteitsdecreet, voor BRUGEL in de Elektriciteitsordonnantie. ${ }^{8 \mathrm{I}}$ Voor de VREG werd dit niet uitdrukkelijk bepaald in het Oprichtingsdecreet. Artikel 23, \$I van het Kaderdecreet Bestuurlijk Beleid bepaalt evenwel dat een publiekrechtelijk vormgegeven extern verzelfstandigd agentschap - zoals de VREG - onder het toezicht staat van de Vlaamse Regering door twee regeringsafgevaardigden of regeringscommissarissen, met name 'een regeringsafgevaardigde aangesteld bij besluit van de Vlaamse Regering op voordracht van de bevoegde minister onder wie het agentschap ressorteert en door een regeringsafgevaardigde aangesteld bij besluit van de Vlaamse Regering op voordracht van de minister bevoegd voor Financiën en Begroting. ${ }^{82}$ Dergelijk besluit werd nog niet genomen, waardoor er voor de VREG, ten tijde van het afsluiten van deze bijdrage, nog geen regeringscommissarissen werden aangesteld.

De regeringscommissarissen houden toezicht op de overeenstemming van de verrichtingen en de werking van de regulator met het algemeen belang en waken over de naleving van de decreten/ordonnanties en hun respectieve uitvoeringsbesluiten. ${ }^{83}$

8I. Artikel 47ter, §§ I van het Waalse Elektriciteitsdecreet en artikel zosepties, §I van de Elektriciteitsordonnantie.

82. De tweede regeringsafgevaardigde heeft dezelfde toezichtsfunctie als de eerste regeringsafgevaardigde, doch zijn toezicht is beperkt tot de beslissingen met een budgettaire of financiële weerslag.

83. Artikel 23, SI van het Kaderdecreet Bestuurlijk Beleid, artikel 47ter, \$3 van het Waalse Elektriciteitsdecreet en artikel zosepties, \$3 van de Elektriciteitsordonnantie. In Vlaanderen is het toezicht ruimer, en waken de regeringscommissarissen in het algemeen bijkomend over de naleving van de wetten, decreten, ordonnanties, het organiek statuut van de VREG en de beheersovereenkomst. Het Vlaamse Energiedecreet bepaalt eveneens dat de bepalingen van het Kaderdecreet Bestuurlijk Beleid van toepassing zijn op de VREG, met uitzondering van artikel 23, § 2, tweede lid, dat niet van toepassing is op bepaalde vertrouwelijke gegevens, zoals vermeld in artikel 3.I.I2 van het Energiedecreet. 
De regeringscommissarissen zetelen met raadgevende stem in de Raad van Bestuur/ het directiecomité. ${ }^{84} \mathrm{Zij}$ worden tijdig uitgenodigd voor alle vergaderingen en worden op dezelfde manier als de leden ervan tijdig in kennis gesteld van de dagorde en alle bijhorende documenten. ${ }^{85} \mathrm{Zij}$ kunnen op elk ogenblik, zonder zich daarvoor te verplaatsen, kennis nemen van alle documenten en geschriften van de regulator. ${ }^{86}$ Voor de VREG werd in het bijzonder bepaald dat de VREG de menselijke en materiële middelen die nodig zijn voor de uitoefening van hun mandaat te hunner beschikking stelt. ${ }^{87}$ Voor de CWaPE werd verduidelijkt dat zij van de voorzitter, elke directeur en van elk personeelslid, alle verduidelijkingen of inlichtingen bekomen, alsook alle onderzoeken voeren, die zij voor de uitoefening van hun taken nuttig achten. ${ }^{88}$ Voor BRUGEL is deze onderzoeksplicht beperkter. De regeringscommissarissen kunnen om toelichtingen of informatie verzoeken, maar enkel aan de voorzitter van de Raad van Bestuur van BRUGEL. Daarnaast kunnen zij weliswaar alle controles uitvoeren die zij voor de uitoefening van hun taken nuttig achten. ${ }^{89}$

De regeringscommissarissen beschikken over een bijzondere beroepsmogelijkheid tegen beslissingen van de regulator. Zij kunnen tegen elke beslissing van de respectieve regulator, die zij in strijd met de decreten/ordonnanties, de uitvoeringsbesluiten of het algemeen belang beschouwen,$^{90}$ beroep instellen. Zij beschikken daarvoor over een termijn van 5 werkdagen (4 werkdagen voor beslissingen van de VREG), te rekenen vanaf de dag van de vergadering waarop de beslissing werd genomen, voor zover de regeringscommissarissen hiervan regelmatig op de hoogte werden gebracht, en, indien dit niet zo is, vanaf de dag waarop zij er kennis van hebben gekregen. Het beroep werkt schorsend. Het beroep wordt aangetekend bij de gewestregering, ${ }^{91}$ die binnen een termijn van ${ }^{15}$ werkdagen (Io werkdagen voor beslissingen van de VREG) vanaf de schorsing een definitief oordeel over de beslissing velt. Indien zij geen (tijdig) oordeel neemt wordt de beslissing definitief. Indien zij de beslissing vernietigt, deelt de gewestregering dit mee aan de regulator..$^{2}$

Voor de VREG werd specifiek nog bepaald dat, wanneer de naleving van de wetten, decreten, ordonnanties en reglementaire besluiten, het organiek statuut van het agentschap of de beheersovereenkomst het vereisen, de bevoegde minister of de regeringsafgevaardigde de Raad van Bestuur kan verplichten om, binnen de door

84. Artikel 23, §2 van het Kaderdecreet Bestuurlijk Beleid, artikel 47ter, §2 van het Waalse Elektriciteitsdecreet en artikel 30 septies, \$2 van de Elektriciteitsordonnantie. Hoewel de Elektriciteitsordonnantie "de Commissie" vermeldt, wordt o.i. de Raad van Bestuur van BRUGEL bedoeld.

85. Artikel 23, §2 van het Kaderdecreet Bestuurlijk Beleid.

86. Artikel 23, §2 van het Kaderdecreet Bestuurlijk Beleid, artikel 47ter, \$2 van het Waalse Elektriciteitsdecreet en artikel zosepties, §2 van de Elektriciteitsordonnantie.

87. Artikel 23, \$2 van het Kaderdecreet Bestuurlijk Beleid.

88. Artikel 47ter, \$2 van het Waalse Elektriciteitsdecreet.

89. Artikel zosepties, §2 van de Elektriciteitsordonnantie.

9o. Voor de VREG, bijkomend: de naleving van de wetten, decreten, ordonnanties, het organiek statuut van de VREG en de beheersovereenkomst.

9I. Voor de VREG bij de bevoegde minister.

92. Artikel 23, \$\$3-5 van het Kaderdecreet Bestuurlijk Beleid, artikel 47ter, \$3 van het Waalse Elektriciteitsdecreet en artikel zosepties, \$3 van de Elektriciteitsordonnantie. 
hem gestelde termijn, te beraadslagen over iedere door hem bepaalde aangelegenheid. ${ }^{93}$ De regeringscommissarissen kunnen dus actief ingrijpen in de werking van de VREG. Een gelijkaardige bepaling werd niet opgenomen voor de CWaPE of voor BRUGEL. Voor de CWaPE werd evenwel bepaald dat de regeringscommissarissen, bij een met redenen omklede beslissing van de Regering, de CWaPE kunnen dwingen om haar toezicht- en controlebevoegdheid uit te oefenen indien de CWaPE herhaaldelijk en zonder reden afziet van elk optreden. ${ }^{94}$

Specifiek voor de CWaPE dienen de regeringscommissarissen elk jaar voor de Waalse Regering een evaluatierapport op te stellen over de activiteiten van de CWaPE. 95

\subsection{Missie en taken}

De missie en de taken van de regulatoren werden telkens uitdrukkelijk opgesomd in de wetten waarbij zij werden opgericht. Aan de respectieve gewestregeringen werd de mogelijkheid gegeven om dit takenpakket verder uit te werken. ${ }^{96}$ Tot op heden heeft geen enkele gewestregering van deze mogelijkheid gebruik gemaakt.

Met het oog op de vervulling van haar missie en taken is de VREG gerechtigd om alle activiteiten te verrichten die rechtstreeks of onrechtstreeks aan de verwezenlijking hiervan bijdragen. ${ }^{97}$ De VREG beschikt dus over de meest ruime bevoegdheden om haar missie en taken te volbrengen. Dergelijke ruime bevoegdheid werd niet uitdrukkelijk voorzien voor de andere regulatoren.

In uitvoering van hun taken kunnen de onderscheiden regulatoren gegevens en inlichtingen bekomen van de verschillende marktpartijen. De modaliteiten hiervoor verschillen per gewest. De VREG kan gegevens en inlichtingen opvragen aan de in het Oprichtingsdecreet limitatief opgesomde marktpartijen, met name een producent, een invoerder van aardgas, een netbeheerder, een aardgasnetbeheerder, een werkmaatschappij, een houder van een leveringsvergunning, een tussenpersoon of hun bestuurders, managers of zelfs personeelsleden. De gecontacteerde partij is verplicht om binnen de door de VREG gestelde termijn haar medewerking te verlenen. De VREG kan de gegevens of inlichtingen die zij alzo verkrijgt enkel

93. Artikel 23, §6 van het Kaderdecreet Bestuurlijk Beleid.

94. Artikel 47ter, §3 bis van het Waalse Elektriciteitsdecreet.

95. Artikel 47ter, $\$ 4$ van het Waalse Elektriciteitsdecreet.

96. Artikel 6, \$2 van het Oprichtingsdecreet (zie ook artikel 3.I.3. van het Vlaamse Energiedecreet)

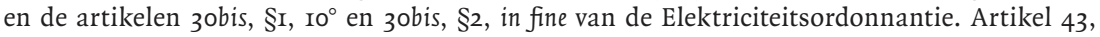
$\S 2,15^{\circ}$ van het Waalse Elektriciteitsdecreet en artikel 36 , $\mathrm{I}, 13^{\circ}$ van het Waalse Aardgasdecreet bepalen dit weliswaar niet uitdrukkelijk, maar laten toe dat 'autres missions' aan de CWaPE kunnen worden opgelegd bij besluit. Hieruit kan ook worden afgeleid (overeenkomstig het adagium, 'qui peut le plus, peut le moins') dat de uitwerking van de reeds gegeven bevoegdheden eveneens bij besluit kan gebeuren.

97. Artikel 7, SI van het Oprichtingsdecreet. Zie ook artikel 3.I.4, §I van het Vlaamse Energiedecreet. 
gebruiken in het kader van de uitoefening van haar taken. $9^{8}$ Het huidige Oprichtingsdecreet voorziet nochtans geen dwangmogelijkheid voor de VREG teneinde deze gegevens te bekomen.

Het nieuwe Vlaamse Energiedecreet doet dit wel, en geeft aan de VREG uitdrukkelijk de bevoegdheid om ter plaatse inzage te vorderen van documenten, er een kosteloze kopie van te maken en alle vereiste zakelijke documenten en andere zakelijke informatiedragers mee te nemen. De VREG heeft daartoe toegang tot de terreinen en de gebouwen. Tot bewoonde lokalen heeft zij enkel toegang na voorafgaande schriftelijke toestemming van de bewoner dan wel een voorafgaande schriftelijke machtiging door een rechter in de politierechtbank. De marktpartij die werd verzocht gegevens en inlichtingen te verstrekken of toegang te verlenen is verplicht om binnen de door de VREG gestelde termijn alle medewerking te verlenen. De door de VREG verkregen inlichtingen kunnen door de VREG alleen worden gebruikt voor de uitoefening van haar taken en bevoegdheden. 99

De CWaPE is gemachtigd de netbeheerders en de beheerders van private netten, producenten, leveranciers en tussenpersonen op de regionale markt, te gebieden om alle noodzakelijke inlichtingen voor de uitvoering van haar taken, mee te delen. Zij motiveert terzake haar beslissing. Bij afwezigheid van reactie, is de voorzitter of een directeur van de CWaPE gemachtigd om de installaties, lokalen en terreinen van de in gebreke blijvende partij te betreden, ${ }^{100}$ kopies te nemen van de gevraagde informatie of deze mee te nemen tegen ontvangstbewijs, en alle noodzakelijke personen te ondervragen en hun antwoorden te noteren. De voorzitter of de directeur stellen een proces-verbaal op, dat bewijskracht heeft tot het tegendeel ervan wordt aangetoond. De te controleren partij is gehouden haar medewerking te verlenen, op straffe van een dwangsom. ${ }^{\text {IoI }}$ Het Waalse Elektriciteitsdecreet verleent de CWaPE bijkomend de bevoegdheid om de rekeningen en de boekhouding van de netbeheerders en de beheerders van private netten, de producenten, de leveranciers en de tussenpersonen op de regionale markt ter plaatse te controleren. ${ }^{\text {I02 }}$

BRUGEL heeft eveneens het recht om zich door een producent, een netbeheerder, de houder van een leveringsvergunning of om het even welke actor op de markt de gegevens en informatie te laten bezorgen die ze nodig heeft voor de uitvoering

98. Artikel 7, \$2 van het Oprichtingsdecreet. Deze bepaling wordt vereenvoudigd in het nieuwe artikel I3.I.2 van het Vlaamse Energiedecreet, dat luidt als volgt: 'de VREG kan aan een marktpartij of de aangestelden, bestuurders, managers en personeelsleden van die marktpartij de gegevens en inlichtingen vragen die nodig zijn voor de uitvoering van haar taken en bevoegdheden, vermeld in de artikelen 3.I.3 en 3.I.4.'

99. Artikel I3.I.2 van het Vlaamse Energiedecreet.

Ioo. Uitzondering is gemaakt voor de bewoonde lokalen in de zin van artikel I5 van de Grondwet. De voorzitter of de directeur van de CWaPE kunnen deze bewoonde lokalen enkel binnengaan in de gevallen die door artikel I5 van de Grondwet worden toegestaan.

IoI. Artikel 47, §I en \$2 van het Waalse Elektriciteitsdecreet. Het Waalse Aardgasdecreet bevat geen overeenkomstige bepalingen.

I02. Artikel 47, §3 van het Waalse Elektriciteitsdecreet. Het Waalse Aardgasdecreet bevat geen bepaling in die zin. 
van haar taken. De partij die wordt gecontacteerd is verplicht hieraan mee te werken binnen de door BRUGEL gestelde termijn. De aldus verkregen informatie of gegevens mogen slechts worden gebruikt in het kader van de bepalingen van de Elektriciteitsordonnantie. ${ }^{103}$ BRUGEL kan de netbeheerders, de leveranciers en de gebruikers van de netten ${ }^{104}$ verzoeken om alle gegevens en informatie nodig voor de uitoefening van haar functie, met uitzondering van de gegevens van de huishoudelijke afnemers, te verschaffen binnen een door haar bepaalde termijn. ${ }^{105}$ BRUGEL beschikt niet over de bevoegdheid om de afgifte van deze gegevens af te dwingen.

De regulatoren hebben een plicht tot beroepsgeheim. Vertrouwelijke gegevens, gegevens die het mogelijk maken de identiteit te kennen van de afnemers en alle commercieel gevoelige gegevens mogen in principe niet worden vrijgegeven. ${ }^{106}$ Gelet op de toepassing van het Kaderdecreet Bestuurlijk Beleid op de VREG, is deze geheimhoudingsplicht minder absoluut dan op het eerste gezicht zou lijken. Artikel 23 van het Kaderdecreet Bestuurlijk Beleid laat de regeringscommissaris immers de mogelijkheid om inzage te nemen van alle documenten en geschriften van de VREG. Daarnaast kan de Vlaamse Regering van de gedelegeerd bestuurder en van de leden van de Raad van Bestuur van de VREG alle inlichtingen en ophelderingen vorderen die zij nodig acht, alsook alle verificaties laten verrichten. ${ }^{\text {I07 }}$

De regulatoren kunnen elke natuurlijke of rechtspersoon opleggen zich te conformeren naar de bepalingen van de onderscheiden elektriciteits- en gasdecreten/ordonnanties en hun uitvoeringsbesluiten. Als deze persoon in gebreke blijft, kunnen zij administratieve geldboeten opleggen teneinde aan de uitoefening van hun missie de nodige daadkracht te kunnen geven. ${ }^{\text {I08 }}$ Beroep tegen de beslissingen tot het opleggen van een administratieve geldboete door de VREG en de CWaPE kunnen

I03. Artikel 3obis, §3 van de Elektriciteitsordonnantie.

I04. Dit is bijzonder ruim, en omvat in principe ook de afnemers. Het kan evenwel betwijfeld worden of dit de bedoeling van de ordonnantiegever was. Tevens kan men zich de vraag stellen wat het nut hiervan zou zijn.

I05. Artikel 35, §I van de Elektriciteitsordonnantie.

Io6. Artikel I5 Oprichtingsdecreet, artikel 47bis van het Waalse Elektriciteitsdecreet en artikel 35, \$2 van de Elektriciteitsordonnantie. Uitzondering wordt gemaakt voor de gevallen waarin gegevens in het kader van een getuigenverhoor in rechte moeten worden vrijgegeven, alsook de uitwisseling van informatie met de Belgische en Europese autoriteiten waarin uitdrukkelijk wordt voorzien in wettelijke of verordenende bepalingen. Zie ook artikel 3.I.I2 van het Vlaamse Energiedecreet. Hoewel niet uitdrukkelijk opgenomen in het Waalse Aardgasdecreet of de Brusselse Aardgasordonnantie gelden de bepalingen van het Waalse Elektriciteitsdecreet en de Brusselse Elektriciteitsordonnantie ook voor de respectieve aardgasmarkten.

I07. K. Deketelaere (ed.), Handboek Milieu- en Energierecht, Brugge, die Keure, 2006, IIo8-IIog.

I08. Artikel 37 van het Vlaamse Elektriciteitsdecreet, artikel 46 van het Vlaamse Aardgasdecreet, artikelen 53-53septies van het Waalse Elektriciteitsdecreet, artikelen 48-48septies van het Waalse Aardgasdecreet en artikel 32 van de Elektriciteitsordonnantie. Zie ook Hoofdstuk III van Titel XIII van het Vlaamse Energiedecreet. 
voor de Rechtbank van Eerste Aanleg worden gebracht. ${ }^{109}$ Tegen een beslissing tot het opleggen van een administratieve geldboete door BRUGEL, staat een georganiseerd administratief beroep open bij de Regering van het Brussels Hoofdstedelijk Gewest. ${ }^{\text {II }}$ In alle gevallen werkt het beroep schorsend.

Hoewel de taken voor de regulatoren op het eerste gezicht quasi hetzelfde zijn, kunnen er toch ook belangrijke verschillen worden genoteerd. Op deze verschillen zal in het volgende onderdeel van deze bijdrage dieper worden ingegaan.

\subsubsection{Algemene taken: toezicht, controle, raad- en adviesverlening}

De VREG, de CWaPE en BRUGEL hebben een algemene opdracht van toezicht en controle op de naleving van de respectieve elektriciteits- en aardgasdecreten en -ordonnanties en hun uitvoeringsbesluiten, alsook de organisatie en de werking van de onderscheiden gewestelijke aardgas- en elektriciteitsmarkten. ${ }^{\text {II }} \mathrm{Zij}$ zien toe op de correcte naleving door de marktpartijen (producenten, leveranciers, netbeheerders en verbruikers) van de geldende decreten, ordonnanties en hun uitvoeringsbesluiten.

Voor BRUGEL werd bijkomend nog uitdrukkelijk bepaald dat zij over een controlebevoegdheid ter plaatse beschikt en dat zij de controles kan laten uitoefenen door haar opdrachthouders. ${ }^{\text {II2 }}$ Voor de CWaPE werd geëxpliciteerd dat zij bevoegd is voor de controle op de naleving door de netbeheerders van hun verplichtingen op basis van de Waalse energieregelgeving, in het bijzonder het technisch reglement, de controle op de naleving van de te vervullen voorwaarden als leverancier, de controle op de uitvoering van de openbaredienstverplichtingen van de netbeheerders en de leveranciers, de controle op de naleving van de voorwaarden gesteld in de vergunningen voor de aanleg van nieuwe directe lijnen of leidingen en de controle op de naleving

Io9. Artikel 37, §4 van het Vlaamse Elektriciteitsdecreet, artikel 47 van het Vlaamse Aardgasdecreet, artikel 53sexies van het Waalse Elektriciteitsdecreet en artikel 48 sexies van het Waalse Aardgasdecreet. Zie ook artikel I3.3.I., \$4 van het Vlaamse Energiedecreet. De bevoegdheid van de Rechtbank van Eerste Aanleg werd overeenkomstig uitgebreid in het Gerechtelijk Wetboek, zie artikel $569,33^{\circ}$ Ger.W.

IIo. Artikel 32 van de Elektriciteitsordonnantie en artikel 24 van de Aardgasordonnantie.

III. Artikelen 5 en 6 , §I, $I^{\circ}$ van het Oprichtingsdecreet, artikel 43 , \$2, lid I van het Waalse Elektriciteitsdecreet, artikel 36 , \$I van het Waalse Aardgasdecreet en artikel 3obis, \$2 van de Elektriciteitsordonnantie. Voor wat betreft de VREG, zie K. Deketelaere (ed.), Handboek Milieu- en Energierecht, Brugge, die Keure, 2006, II06-IIo8, en L. Deridder, 'Recente ontwikkelingen in het gewestelijk energiebeleid en -recht' in K. Deketelaere (ed.), Jaarboek Energierecht 2004, Antwerpen, Intersentia, 2005, 9I-98. Voor wat betreft de CWaPE, zie G. Block en D. Haverbeke, 'Le nouveau décret wallon relatif à l'organisation du marché régional de l'électricité et les incidences communales', Mouv. Comm. 200I, 357. Voor wat betreft BRUGEL, zie M. Schurmans en W. Vandenberghe, 'Voornaamste ontwikkelingen in het gewestelijke energiebeleid en -recht in 2007-2008' in K. Deketelaere en B. Delvaux (eds.), Jaarboek Energierecht 2007, Antwerpen, Intersentia, 2008, 205-207, en G. Block en L. Hage, 'Les grands axes de la réforme des marchés de l'électricité et du gaz en Région de Bruxelles-Capitale à la suite de l'ordonnance du I4 décembre 2006', J.T. 2007, 630.

II2. Artikel zobis, $\$ 2, \mathrm{II}^{\circ}$ van de Elektriciteitsordonnantie. 
van de bepalingen inzake de bevordering van hernieuwbare energiebronnen voor elektriciteit en aardgas, en kwalitatieve warmtekrachtkoppeling. ${ }^{\mathrm{II}}$

De CWaPE en BRUGEL hebben bijkomend een algemene raadgevende en adviserende taak. Zo geven zowel de CWaPE als BRUGEL adviezen, voeren zij studies en onderzoeken uit en doen zij voorstellen en aanbevelingen aan de onderscheiden overheden. ${ }^{\text {II } 4}$ De CWaPE kan dit in alle gevallen doen op eigen initiatief dan wel op verzoek van de bevoegde minister. ${ }^{115}$ In principe dient de CWaPE advies te verlenen binnen 30 dagen nadat zij schriftelijk daartoe werd verzocht. Indien ze geen advies geeft binnen deze termijn, wordt het advies geacht gunstig te zijn. ${ }^{\text {II }}$ De Elektriciteitsordonnantie geeft BRUGEL opdracht onderzoeken en studies betreffende de Brussels elektriciteits- en de aardgasmarkt uit te voeren, op eigen initiatief of op vraag van de bevoegde Minister. ${ }^{117}$ BRUGEL moet daarnaast adviezen, studies en gemotiveerde beslissingen geven, en voorstellen indienen, in de gevallen dat de Elektriciteitsordonnantie, de Aardgasordonnantie of hun uitvoeringsbesluiten hierin voorzien. ${ }^{\text {II8 }}$ Tenzij een specifieke bepaling hierover anders beslist, moet BRUGEL haar advies geven binnen een termijn van veertig dagen vanaf de datum van ontvangst van de schriftelijke aanvraag. Indien ze geen advies geeft binnen deze termijn, wordt BRUGEL geacht een gunstig advies te hebben gegeven. BRUGEL is verplicht om haar adviezen, studies en beslissingen te publiceren binnen een termijn van 2I dagen, behalve wat betreft de elementen waarvoor vertrouwelijkheid is vereist. ${ }^{\text {II } 9}$

Het Oprichtingsdecreet bevat voor de VREG geen adviseringsplicht ten behoeve van de Vlaamse Regering terzake. ${ }^{120}$ Dit betekent nochtans niet dat de Vlaamse Regering de VREG niet raadpleegt met het oog op het uitbrengen van advies. Zo heeft de Vlaamse Regering de VREG al meerdere malen gecontacteerd voor advies inzake (voor)ontwerpen van decreten en/of besluiten. Daarnaast verleent de VREG ook op

II3. Artikelen $43, \S 2, I^{\circ}, 3^{\circ}, 4^{\circ}, 6^{\circ}$ en $8^{\circ}$ van het Waalse Elektriciteitsdecreet en artikel $36, \S \mathrm{I}, \mathrm{I}^{\circ}, 3^{\circ}, 4^{\circ}$, $6^{\circ}$ en $8^{\circ}$ van het Waalse Aardgasdecreet.

II4. De artikelen 43, §2 en 43bis, §I van het Waalse Elektriciteitsdecreet en het artikel zobis, §2 en \$2, $I^{\circ}$ en $2^{\circ}$ van de Elektriciteitsordonnantie.

II5. Artikel 43bis, \$2 van het Waalse Elektriciteitsdecreet. Hoewel dit niet uitdrukkelijk werd bepaald voor het Waalse Aardgasdecreet, gelden deze bepalingen evenzeer voor de Waalse aardgasmarkt. De CWaPE heeft, bijvoorbeeld, tot taak de Waalse Gewestregering te adviseren over de inhoud van de openbaredienstverplichtingen van de leveranciers en de netbeheerders.

II6. Artikel 43bis, §I van het Waalse Elektriciteitsdecreet. Dit wordt niet uitdrukkelijk hernomen in het Waalse Aardgasdecreet.

II7. Artikel 3obis, $\$ 2,2^{\circ}$ van de Elektriciteitsordonnantie.

II8. Artikel 30 bis, $\$_{2}, I^{\circ}$ van de Elektriciteitsordonnantie. Bijvoorbeeld het geven van advies op het investeringsplan van de netbeheerders, het geven van advies betreffende de criteria, de voorwaarden en de procedure voor de toekenning van groenestroomcertificaten en het indienen van voorstellen tot aanpassing van het door de distributienetbeheerder of de beheerder van het gewestelijk transmissienet ingediende voorstel van technisch reglement voor het beheer van het distributienet en het gewestelijk transmissienet.

II9. Artikel zobis, $\$ 2,12^{\circ}$ van de Elektriciteitsordonnantie.

I20. In tegenstelling tot het oude artikel 28 van het Vlaamse Elektriciteitsdecreet. Zie de kritiek op het ontbreken naar een verwijzing dienaangaande bij L. Deridder, 'Recente ontwikkelingen in het gewestelijk energiebeleid en -recht' in K. Deketelaere (ed.), Jaarboek energierecht 2004, Antwerpen, Intersentia, 2005, 95. 
eigen initiatief advies. ${ }^{21}$ Het Vlaamse Energiedecreet vult deze anomalie op. De VREG krijgt in dit decreet expliciet een adviserende taak, op verzoek of op eigen initiatief, ten opzichte van de Minister of de Vlaamse Regering. De VREG verkrijgt tevens de bevoegdheid om studies of onderzoeken betreffende de elektriciteitsen de aardgasmarkt uit te voeren, en dit op eigen initiatief dan wel verzoek van de minister of de Vlaamse Regering. ${ }^{\text {I22 }}$

\subsubsection{Bijzondere taken}

\section{Leveringsvergunningen}

De VREG is bevoegd inzake de toekenning, de wijziging en de intrekking van de leveringsvergunningen voor de leveranciers van aardgas en elektriciteit in het Vlaamse Gewest. ${ }^{23}$ Leveringsvergunningen voor de levering van elektriciteit en aardgas in het Waalse Gewest worden uitsluitend verleend door de bevoegde Waalse minister, weliswaar na gemotiveerd advies van de CWaPE. ${ }^{124}$ De CWaPE houdt toezicht op het vervullen van de voorwaarden om als leverancier te kunnen worden erkend en om deze hoedanigheid te behouden. ${ }^{\mathrm{I} 25}$ Indien een leverancier de inhoud van zijn leveringsvergunning niet respecteert of de inhoud van de Waalse Elektriciteits- of Aardgasdecreten niet volgt, dan schrijft zij deze leverancier aan zich terzake te conformeren binnen een bepaalde termijn. In deze termijn nodigt zij de leverancier uit om zijn opmerkingen mee te delen, dan wel alle maatregelen te nemen om de voor-

I2I. Zo bv. het advies dd. 29 april 2008 van de VREG aan de Vlaamse minister, bevoegd voor het Energiebeleid, met betrekking tot het voorstel tot wijziging van de bijzondere wet tot hervorming van de instellingen op het vlak van de energiebevoegdheden.

122. Artikel 3.I.3, $5^{\circ}$ van het Vlaamse Energiedecreet.

123. Artikel $7, \S 3,5^{\circ}$ van het Oprichtingsdecreet. Dit werd overgenomen in artikel 3.I.4., \$2, $5^{\circ}$ van het Vlaamse Energiedecreet. De procedure voor het verkrijgen van een vergunning voor de levering van elektriciteit is beschreven in het besluit van de Vlaamse Regering van 15 juni 200 I met betrekking tot de leveringsvergunningen voor elektriciteit, B.S. 5 september 20oI. De procedure voor het verkrijgen van een vergunning voor de levering van aardgas is beschreven in titel III van het besluit van de Vlaamse Regering van II oktober 2002 houdende de organisatie van de aardgasmarkt, B.S. I8 oktober 2002.

I24. Artikel I6 van het besluit van de Waalse Regering van 2I maart 2002 betreffende de vergunning voor de levering van elektriciteit, B.S. 27 april 2002 en artikel I6 van het besluit van de Waalse Regering van I6 oktober 2003 betreffende de vergunning voor gaslevering, B.S. I4 november 2003 .

I25. Artikel 43, $22,3^{\circ}$ van het Waalse Elektriciteitsdecreet en artikel 36 , §I, $0^{\circ}$ van het Waalse Aardgasdecreet. Op basis van artikel $43, \S 2,4^{\circ}$ van het Waalse Elektriciteitsdecreet en artikel 36 , SI, $4^{\circ}$ van het Waalse Aardgasdecreet oefent de CWaPE ook controle uit op de naleving door de leverancier van de in de respectieve decreten vastgestelde openbaredienstverplichtingen. Zij kan daartoe, op basis van artikel $43, \S 2,5^{\circ}$ van het Waalse Elektriciteitsdecreet en artikel $36, \$$ I, $5^{\circ}$ van het Waalse Aardgasdecreet, in voorkomend geval, via reglementaire weg, tevens de methode bepalen voor de berekening van de werkelijke kosten van de openbare dienstverplichtingen. Daarnaast kan zij controle uitoefenen op de berekeningen uitgevoerd door elk betrokken bedrijf overeenkomstig die methodologie. 
opgestelde voorwaarden en verplichtingen na te leven. De CWaPE kan vervolgens een advies geven over de intrekking van de vergunning(en). ${ }^{\mathrm{I} 6}$

De levering van elektriciteit en aardgas in het Brussels Hoofdstedelijk Gewest is onderworpen aan het voorafgaandelijk bekomen van een leveringsvergunning door de Brusselse Hoofdstedelijke Regering, op gemotiveerd voorstel van BRUGEL. Hierbij geldt dat - net zoals bij CWaPE het geval is - indien een leverancier de inhoud van de betreffende regelgeving niet naleeft, BRUGEL de bevoegde Minister hiervan op de hoogte brengt. BRUGEL schrijft deze leverancier vervolgens aan om zijn bemerkingen schriftelijk te bezorgen en, in voorkomend geval, om de passende maatregelen te treffen voor het rechtzetten van de toestand, binnen een bepaalde termijn. BRUGEL kan vervolgens een advies verlenen over de intrekking van de vergunning(en). ${ }^{127}$

\section{Aanduiding van en de controle op de netbeheerders}

Er zijn tevens enkele opmerkelijke verschillen te noteren tussen de bevoegdheden van de regelgevende instanties voor wat betreft de aanduiding van en de controle op de netbeheerders. Zo is de VREG in het algemeen bevoegd voor de aanwijzing en de herroeping van de aanwijzing van de elektriciteitsnetbeheerders en de aardgasnetbeheerders. $^{128}$

De CWaPE kan dit niet. Zij kan enkel controle en toezicht uitoefenen op het 'respect par les gestionnaires de réseaux, de leurs obligations imposées par le présent décret et ses arrêtés d'exécution, notamment le règlement technique'. ${ }^{129}$ Deze bevoegdheid voegt in feite weinig toe aan de algemene controletaak van de regulator op de naleving door de onderscheiden marktpartijen van de elektriciteits- en de aardgasregel-

I26. Artikel 22 van het besluit van de Waalse Regering van 2I maart 2002 betreffende de vergunning voor de levering van elektriciteit, B.S. 27 april 2002 en artikel 22 van het besluit van de Waalse Regering van 16 oktober 2003 betreffende de vergunning voor gaslevering, B.S. I4 november 2003 .

I27. Artikel 2I Elektriciteitsordonnantie, uitgevoerd door het Besluit van de Brusselse Hoofdstedelijke Regering van I8 juli 2002 houdende de criteria en de procedure tot toekenning, hernieuwing, overdracht en intrekking van een leveringsvergunning voor elektriciteit, B.S. 6 november 2002, en het besluit van de Brusselse Hoofdstedelijke Regering van 6 mei 2004 houdende de criteria en de procedure tot toekenning, hernieuwing, overdracht en intrekking van een leveringsvergunning voor gas en houdende wijziging van het besluit van de Brusselse Hoofdstedelijke Regering van I8 juli 2002 houdende de criteria en de procedure tot toekenning, hernieuwing, overdracht en intrekking van een leveringsvergunning voor elektriciteit, B.S. 28 juni 2004.

128. Artikel $7, \S_{3}, 3^{\circ}$ van het Oprichtingsdecreet. Dit werd overgenomen in artikel 3.I.4, $\$ 2,3^{\circ}$ van het Vlaamse Energiedecreet.

I29. Artikel 43, \$2, I van het Waalse Elektriciteitsdecreet en artikel 36, §I, Ivan het Waalse Aardgasdecreet. Op basis van artikel 43, \$2, $4^{\circ}$ van het Waalse Elektriciteitsdecreet en artikel 36, §I, $4^{\circ}$ van het Waalse Aardgasdecreet oefent de CWaPE ook controle uit op de naleving door de netbeheerder van in de respectieve decreten vastgestelde openbaredienstverplichtingen. Zij kan daartoe, op basis van artikel $43, \S 2,5^{\circ}$ van het Waalse Elektriciteitsdecreet en artikel 36, $\$ I, $5^{\circ}$ van het Waalse Aardgasdecreet, in voorkomend geval, via reglementaire weg, tevens de methode bepalen voor de berekening van de werkelijke kosten van de openbare dienstverplichtingen. Daarnaast kan zij controle uitoefenen op de berekeningen uitgevoerd door elk betrokken bedrijf overeenkomstig die methodologie. 
geving. De distributienetbeheerders op de Waalse energiemarkt worden aangeduid door de Waalse Gewestregering, weliswaar na advies van de CWaPE. ${ }^{1{ }^{\circ}}$ De CWaPE oefent terzake ook controle uit door de goedkeuring van de reglementen en de standaardovereenkomsten voor aansluiting en toegang van de netbeheerders, en van hun wijzigingen. ${ }^{\mathrm{I}}{ }^{\mathrm{I}}$

Daarnaast stelt de CWaPE de informatie vast die de netbeheerder moet verstrekken, met het oog op het opstellen van energiebalansen en het rapport voorzien door richtlijn 2006/32 van het Europees Parlement en de Raad van 5 april 2006 betreffende energie-efficiëntie bij het eindgebruik en energiediensten en houdende intrekking van Richtlijn 93/76/EEG van de Raad, wat de elektriciteit en het gas betreft. ${ }^{132}$ Enigszins verrassend kan worden gelezen dat de CWaPE ook bevoegd is voor de goed-

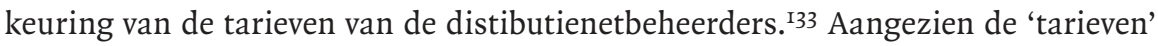
een federale bevoegdheid is, is de Waalse decreetgever dan ook niet bevoegd om de CWaPE deze tarieven te laten goedkeuren. Deze bepaling lijkt dan ook in strijd met artikel §6, §I, VII van de BWHI.

Deze bevoegdheid werd evenwel bij de stemming van de decreten van 17 juli 2008 'modifiant le décret du 12 avril 200 r relatif à l'organisation du marché régional de l'électricité' en 'modifiant le décret du I9 décembre 2002 relatif à l'organisation du marché régional du gaz' ingevoegd na een amendement vanuit de idee dat de federale bevoegdheid inzake de goedkeuring van tarieven voor de distributie van gas en elektriciteit in de toekomst toch zal worden geregionaliseerd. De bevoegdheden van de CWaPE werden dus reeds aangepast aan de toekomstige bevoegdheidsherverdeling en de goedkeuring en inwerkingtreding van een aangepaste BWHI. 34 Vanzelfsprekend zijn deze bepalingen nog niet in werking. De datum van inwerkingtreding van artikel $43, \S 2,14^{\circ}$ van het Waalse Elektriciteitsdecreet en artikel 36 , §I, I2 ${ }^{\circ}$ van het Waalse Aardgasdecreet wordt bepaald door de Waalse Regering, uiteraard na de inwerkingtreding van de wijzigingen aan de BWHI.

I30. Artikel Io, §I van het Waalse Elektriciteitsdecreet en artikel Io, SI van het Waalse Aardgasdecreet.

I3I. Artikel 43, $\$ 2,2^{\circ}$ van het Waalse Elektriciteitsdecreet en artikel 36, SI, $2^{\circ}$ van het Waalse Aardgasdecreet.

I32. Artikel $43, \S 2,7^{\circ}$ van het Waalse Elektriciteitsdecreet en artikel 36 , §I, $7^{\circ}$ van het Waalse Aardgasdecreet.

I33. Artikel $43, \S 2, \mathrm{I} 4^{\circ}$ van het Waalse Elektriciteitsdecreet en artikel 36 , $\S \mathrm{I}, \mathrm{I}^{\circ}$ van het Waalse Aardgasdecreet.

134. Amendement (M. Lebrun) op het decreetsvoorstel modifiant le décret du I2 avril 200 r relatif à l'organisation du marché régional de l'électricité, Parl. St. W.Gew.R, 2007-2008, nr. 813/ro, en amendement (M. Grommes et consorts) op het decreetsvoorstel modifiant le décret du Ig décembre 2002 relatif à l'organisation du marché régional de gaz, ParL. St. W.Gew.R. 20072008 , nr. $814 / 3$. 
De Brusselse energiemarkt heeft zowel een distributienet ${ }^{135}$ als een gewestelijk transmissienet. ${ }^{136}$ Sibelga werd aangewezen als distributienetbeheerder voor de Brusselse elektriciteits- en aardgasmarkt. ${ }^{137}$ Elia System Operator werd aangewezen als beheerder van het gewestelijk elektriciteitstransmissienet. ${ }^{138}$ Via haar algemene toezichthoudende taak oefent BRUGEL controle uit op deze netbeheerders.

\section{Technische reglementen}

De VREG is bevoegd voor het opstellen van de technische reglementen voor het beheer van het elektriciteits- en gasdistributienet, de toegang ertoe en de vereisten voor het aanleggen van directe lijnen en leidingen, alsook de gedragscodes voor de toegang tot het distributienet. ${ }^{139}$ Deze technische reglementen en gedragscodes zijn onderworpen aan de goedkeuring van de bevoegde Vlaamse minister. ${ }^{{ }^{40}}{ }^{\circ}$ De VREG oefent tevens het toezicht en de controle op deze technische reglementen uit.

Het Vlaams Technisch Reglement Distributie Elektriciteit en het Vlaams Technisch Reglement Distributie Gas bepalen uitdrukkelijk dat de distributienetbeheerders 'overleg' zullen plegen met als doel de coördinatie te verzorgen bij het opstellen van modelcontracten, reglementen, technische voorschriften, procedures en formulieren in het kader van de technische reglementen. Deze modelcontracten, reglementen, technische voorschriften, procedures en formulieren, alsook alle wijzigingen die eraan worden aangebracht, worden pas van kracht als ze twee maanden voor hun inwerkingtreding voor nazicht aan de respectieve regulator werden bezorgd. ${ }^{\text {III }}$

I35. Gedefinieerd in artikel 2, $\mathrm{I}^{\circ}$ van de Elektriciteitsordonnantie: netten met een spanning van lager dan $36 \mathrm{kV}$ op het grondgebied van het Brussels Hoofdstedelijk Gewest.

I36. Gedefinieerd in artikel 2, $\mathrm{II}^{\circ}$ van de Elektriciteitsordonnantie: netten met een nominale spanning van $36 \mathrm{kV}$ op het grondgebied van het Brussels Hoofdstedelijk Gewest.

I37. Op basis van artikel 36 van de Elektriciteitsordonnantie werd Sibelga eerst 'voorlopig' aangewezen als distributienetbeheerder, en werd Elia System Operator tevens 'voorlopig' aangewezen als beheerder van het gewestelijk transmissienet. Sibelga werd op I3 juli 2006, telkens bij besluit van de Brusselse Hoofdstedelijke Regering, aangeduid als beheerder van de verdeelnetwerken voor elektriciteit en gas, B.S. I september 2006.

I38. Besluit van I3 juli 2006 van de Brusselse Hoofdstedelijke Regering houdende aanstelling van de N.V. Elia als beheerder van het gewestelijk elektriciteitsvervoernetwerk, B.S. I september 2006.

I39. Artikel $7, \S_{3}, 4^{\circ}$ van het Oprichtingsdecreet. Zie ook de artikelen 8 en I4 van het Vlaamse Elektriciteitsdecreet en de artikelen 9 en 15 van het Vlaamse Aardgasdecreet. Zie ook artikel 3.I.4, \$2, $6^{\circ}$ van het Vlaamse Energiedecreet, dat terzake niet meer spreekt van technische reglementen en gedragscodes, maar beiden omvormt tot een geheel dat de naam 'technisch reglement' krijgt.

I40. Artikel 7, \$4 van het Oprichtingsdecreet. Zie ook het Ministerieel Besluit van 4 april 2007 houdende goedkeuring van het technisch reglement distributie elektriciteit Vlaams Gewest, B.S. 4 mei 2007 ('Vlaams Technisch Reglement Distributie Elektriciteit'), en het Ministerieel Besluit van 4 april 2007 houdende goedkeuring van het technisch reglement distributie gas Vlaams Gewest, B.S. 30 april 2007 ('Vlaams Technisch Reglement Distributie Aardgas').

I4I. Artikelen I.3.I.I en I.3.I.2 van het Vlaams Technisch Reglement Distributie Elektriciteit en van het Vlaams Technisch Reglement Distributie Gas. Een vroegere versie van deze Vlaamse technische reglementen bepaalde dat deze modelcontracten reglementen, procedures en formulieren 'slechts in werking treden' wanneer ze door de VREG uitdrukkelijk zijn aanvaard. Voor een kritiek hierop, zie L. Deridder, 'Recente ontwikkelingen in het gewestelijk energiebeleid en -recht', in K. Deketelaere (ed.), Jaarboek Energierecht 2004, Intersentia, 2005, 96-97. Deze Vlaamse technische reglementen werden ondertussen aangepast, o.a. ook aan de inhoud van de technische reglementen van het Waalse Gewest. 
Dit 'nazicht' zal alleszins beperkt moeten zijn tot de naleving van de bepalingen van het Vlaamse Elektriciteits- en Aardgasdecreet, en de bijhorende uitvoeringsbesluiten. De VREG is niet bevoegd om de naleving van de regels van de mededinging te controleren, in tegenstelling tot de bijzondere bevoegdheden die de CREG op dit vlak heeft (zie supra).

Daarnaast stelt zich de vraag wat wordt bedoeld met 'inwerkingtreding'. Kunnen deze modelcontracten, enz. niet in werking treden voordat zij zijn goedgekeurd door de regulator? Krachtens de tekst van het technisch reglement kan dit schijnbaar niet. Een overeenkomst is nochtans gesloten zodra er wilsovereenstemming is tussen alle partijen over het voorwerp en de prijs. De VREG is evenmin gepercipieerd als een toezichthoudende instantie die de (ontwerp)reglementen van een distributienetbeheerder dient goed of af te keuren. Het Vlaamse Elektriciteits- of het Vlaamse Aardgasdecreet verlenen haar zulke bevoegdheid niet.

Hoewel de technische reglementen voor de distributie van elektriciteit en voor aardgas moeten worden goedgekeurd door de Vlaamse Regering, is de VREG dus decretaal niet bevoegd om in te grijpen in contractuele en/of reglementaire verhoudingen. De contracten zijn dan ook geldig zodra zij zijn gesloten. De reglementen zijn geldig zodra zij zijn goedgekeurd door de netbeheerder. Zij zijn tegenstelbaar zodra zij op de door de wet voorgeschreven wijze werden bekendgemaakt. De regulator zou hoogstens een administratieve geldboete kunnen opleggen wegens inbreuk op een verplichting van het technisch reglement.

De CWaPE stelt eveneens een technisch reglement op voor het beheer van de distributienetten en de toegang ertoe. In tegenstelling tot de VREG is de CWaPE er evenwel decretaal toe verplicht om dit te doen in overleg met de netbeheerders. Het technisch reglement wordt vervolgens voor goedkeuring voorgelegd aan de Waalse Regering. ${ }^{\mathrm{I} 42}$

Het Waals Technisch Reglement Distributie Elektriciteit en het Waals Technisch Reglement Lokale Transmissie Elektriciteit bevatten een gelijkaardige verplichting tot nazicht voor 'les conditions générales des contrats, y compris la convention de collaboration à conclure en vertu du présent règlement ainsi que toutes modi-

I42. Artikel I3 van het Waalse Elektriciteitsdecreet en artikel I4 van het Waalse Aardgasdecreet. Zie het besluit van de Waalse Regering van 24 mei 2007 betreffende de herziening van het technisch reglement voor het beheer van de elektriciteitsdistributienetten in het Waalse Gewest alsook de toegang daartoe, B.S. 24 juli 2007 (hierna 'Waals Technisch Reglement Distributie Elektriciteit'), het besluit van Waalse Regering van 24 mei 2007 betreffende de herziening van het technisch reglement voor het beheer van het lokale elektriciteitstransmissienet in het Waalse Gewest en de toegang ertoe, B.S. 24 juli 2007 (hierna 'Waals Technisch Reglement Lokale Transmissie Elektriciteit') en het besluit van de Waalse Regering van I2 juli 2007 tot herziening van het technisch reglement voor het beheer van de gasdistributienetten en de toegang daartoe, B.S. 2I augustus 2007 (hierna 'Waals Technisch Reglement Distributie Aardgas'). 
fications qui y sont apportées'. ${ }^{43}$ Deze moeten aan de CWaPE worden verzonden, 'sans délai et en tout cas deux mois avant leur entrée en vigueur'. Volgens het Waals Technisch Reglement Distributie Elektriciteit en het Waals Technisch Reglement Lokale Transmissie Elektriciteit moeten deze algemene voorwaarden en overeenkomsten evenwel niet worden goedgekeurd door de CWaPE, maar moeten zij enkel aan haar worden meegedeeld. Dit is een groot verschil met de Vlaamse technische reglementen, die uitdrukkelijk in een goedkeuringsbevoegdheid voorzien. Het Waals Technisch Reglement Distributie Aardgas bevat een gelijkaardige bepaling. ${ }^{\mathrm{I} 44}$

In het Brussels Hoofdstedelijk Gewest formuleren de respectieve netbeheerders eerst een voorstel van technisch reglement. Vervolgens verleent BRUGEL een advies over dit voorstel. De Brusselse Hoofdstedelijke Regering heeft het laatste woord en beslist om de technische reglementen aan te nemen of te weigeren. ${ }^{45}$ Een bijzondere procedure werd voorzien waarbij BRUGEL, alvorens advies te geven, aanpassingen kan voorstellen aan de voorstellen van technisch reglement die haar worden voorgelegd. Modelcontracten, reglementen etc. moeten in het Brussels Hoofdstedelijk Gewest niet ter nazicht worden meegedeeld of ter informatie worden voorgelegd.

Steun voor de productie van groene stroom (en elektriciteit uit WKK)

Ter bevordering van de productie van groene stroom hebben de gewesten onder andere een bijzondere vorm van steun uitgewerkt door middel van de toekenning van groenestroomcertificaten, ${ }^{146}$ of groene certificaten, ${ }^{\mathrm{I} 47}$ aan producenten van

I43. Zie artikel 6 van het Waals Technisch Reglement Lokale Transmissie Elektriciteit en artikel I4 van het Waals Technisch Reglement Distributie Elektriciteit.

I44. Het Waals Technisch Reglement Distributie Aardgas stelt wel dat de distributienetbeheerder bepaalde documenten (waaronder 'les conditions générales des contrats de raccordement et d'accès à conclure', 'les formulaires nécessaires pour l'échange de données' en 'les tarifs applicables'), minstens I5 dagen voor hun inwerkingtreding, publiekelijk toegankelijk moet maken via het internet. Deze documenten moeten eveneens, minstens 6o dagen voor hun inwerkingtreding, met uitzondering van de toepasselijke tarieven, worden meegedeeld aan de CWaPE. De CWaPE heeft terzake geen goed- of afkeuringsbevoegdheid.

I45. Artikel gter van de Elektriciteitsordonnantie en artikel 9 van de Aardgasordonnantie. Zie het besluit van de Brusselse Hoofdstedelijke Regering van I3 juli 2006 houdende goedkeuring van het technisch reglement voor het beheer van het gewestelijk transmissienet voor elektriciteit, B.S. 28 september 2006, het besluit van de Brusselse Hoofdstedelijke Regering van I3 juli 2006 houdende goedkeuring van het technisch reglement voor het beheer van het gasdistributienet in het Brussels Hoofdstedelijk Gewest en van de toegang ertoe, B.S. I8 september 2006 en het besluit van de Brusselse Hoofdstedelijke Regering van I3 juli 2006 houdende goedkeuring van het technisch reglement voor het beheer van het elektriciteitsdistributienet in het Brussels Hoofdstedelijk Gewest en van de toegang ertoe, B.S. 29 november 2006.

I46. Artikel 2, $17^{\circ}$ van het Vlaamse Elektriciteitsdecreet: 'een overdraagbaar immaterieel goed dat aantoont dat een producent in een daarin aangegeven jaar een daarin aangegeven hoeveelheid groene stroom, uitgedrukt in kWh, heeft opgewekt.' Artikel 2, $8^{\circ}$ van de Elektriciteitsordonnantie: 'overdraagbare en verhandelbare titel toegekend voor opgewekte groene elektriciteit of elektriciteit geproduceerd op basis van warmtekrachtkoppeling, volgens de voorwaarden bepaald krachtens artikel 28.'

I47. Artikel 2, $14^{\circ}$ van het Waalse Elektriciteitsdecreet: 'titre transmissible octroyé aux producteurs d'électricité verte en vertu de l'article 38 et destiné, via les obligations imposées aux fournisseurs et gestionnaires de réseaux, à soutenir le développement d'installations de production d'électricité verte.' 
hernieuwbare energie. De VREG is verantwoordelijk voor de erkenning van de installaties voor de productie van elektriciteit uit hernieuwbare energiebronnen. In het Brussels Hoofdstedelijk Gewest moet een installatie voor de productie van groene stroom of van warmtekracht het voorwerp uitmaken van een voorafgaandelijke certifiëring door BRUGEL opdat groenestroomcertificaten zouden kunnen worden toegekend. ${ }^{148}$

Sites voor de productie van elektriciteit uit hernieuwbare energiebronnen of warmtekrachtkoppeling in Wallonië moeten eveneens voorafgaandelijk worden gecertificeerd. ${ }^{\mathrm{I} 9}$ De CWaPE is tevens bevoegd om voor bepaalde installaties de jaarlijkse

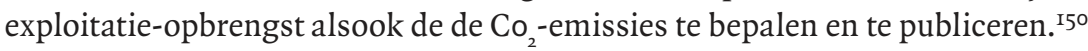

DeVREG en de CWaPE zijn verantwoordelijkvoor de toekenning van groene(stroom)certificaten op hun onderscheiden grondgebied. ${ }^{151}$ In het Brussels Hoofdstedelijk Gewest worden groenestroomcertificaten toegekend door de opdrachthouders bij BRUGEL. ${ }^{152}$ Deze certificaten zijn immateriële goederen. Zij worden opgenomen in een gegevensbank die door de regulatoren wordt beheerd. ${ }^{153}$

Iedere leverancier aan eindafnemers, aangesloten op het distributienet of transmissienet, is verplicht om aan de bevoegde reguleringsinstantie een aantal certificaten af te leveren. ${ }^{154}$ Dit aantal komt overeen met een jaarlijks stijgende minimum hoeveelheid aan de afnemers te leveren groene elektriciteit. 155 Bij ontstentenis tijdig een voldoende aantal certificaten in te leveren, leggen de regulatoren een administra-

I48. Artikelen 2 en 3 van het Besluit van de Brusselse Hoofdstedelijke Regering van 6 mei 2004 betreffende de promotie van groene elektriciteit en kwaliteitswarmtekrachtkoppeling, B.S. 28 juni 2004 .

I49. Artikel 36 van het Waalse Elektriciteitsdecreet en artikel 6 van het Besluit van de Waalse Regering van 30 november 2006 tot bevordering van de groene elektriciteit, B.S. 29 december 2006.

I50. Artikel 43, \$2, $10^{\circ}$ van het Waalse Elektriciteitsdecreet.

I5I. Artikel 7, §3, $9^{\circ}$ van het Vlaamse Elektriciteitsdecreet en de artikelen 38 , \$7 en 43, §2, $9^{\circ}$ van het Waalse Elektriciteitsdecreet. Zie ook artikel 7.I.I van het Vlaamse Energiedecreet.

I52. Artikel 28, §I, in fine van de Elektriciteitsordonnantie.

153. Artikel $7,6^{\circ}$ van het Vlaamse Elektriciteitsdecreet en artikel I3 van het Besluit van de Vlaamse Regering van 5 maart 2004 inzake de bevordering van elektriciteitsopwekking uit hernieuwbare energiebronnen, B.S. 23 maart 2004. Artikel 43, $\mathrm{II}^{\circ}$ van het Waalse Elektriciteitsdecreet en artikel 2I van het Besluit van de Waalse Regering van 30 november 2006 tot bevordering van de groene elektriciteit, B.S. 29 december 2006. Artikel ig Besluit van de Brusselse Hoofdstedelijke Regering van 6 mei 2004 betreffende de promotie van groene elektriciteit en van kwaliteitswarmtekrachtkoppeling, B.S. 28 juni 2004.

I54. Artikel 23 van het Vlaamse Elektriciteitsdecreet, artikel 39 van het Waalse Elektriciteitsdecreet en artikel 28 Elektriciteitsordonnantie. Zie ook artikel 7.I.Io van het Vlaamse Energiedecreet.

I55. Artikel 23, §2 van het Vlaamse Elektriciteitsdecreet, artikel 25 van het Besluit van de Waalse Regering van 30 november 2006 tot bevordering van de groene elektriciteit, B.S. 29 december 2006 en (voor vanaf het jaar 2008) het Besluit van de Brusselse Hoofdstedelijke Regering van 29 maart 2007 houdende vaststelling van de quota voor groenstroomcertificaten voor het jaar 2008 en de volgende genomen in toepassing van artikel 28 , \$2, derde lid van de ordonnantie van I9 juli 200 I betreffende de organisatie van de elektriciteitsmarkt in het Brussels Hoofdstedelijk Gewest, B.S. 30 mei 2007. 
tieve geldboete op per ontbrekend certificaat. ${ }^{156}$ De regulatoren beschikken terzake niet over een appreciatiebevoegdheid, en zijn verplicht de boetes op te leggen. ${ }^{157}$

Het Vlaamse Gewest kent daarnaast nog een bijzondere procedure voor de bevordering van de opwekking van elektriciteit (en warmte) uit kwalitatieve warmtekrachtinstallaties (WKK's) via de toekenning van warmtekrachtcertificaten. ${ }^{158}$ De VREG is bevoegd voor de erkenning van deze WKK's en de toekenning van warmtekrachtcertificaten. ${ }^{159}$ Iedere leverancier, die levert aan eindafnemers, aangesloten op een distributienet of het transmissienet, is verplicht om vanaf 2006 aan de VREG jaarlijks een bepaald aantal warmtekrachtcertificaten voor te leggen. Dit aantal komt overeen met een jaarlijks stijgende minimum hoeveelheid aan de afnemers te leveren elektriciteit, opgewekt via kwalitatieve warmtekrachtkoppeling. ${ }^{160}$ Ook hier legt de regulator (VREG) een administratieve geldboete op per ontbrekend certificaat. ${ }^{16 \mathrm{I}}$ Volledigheidshalve moet nog worden vermeld dat de VREG tevens over de bevoegdheid beschikt om groenewarmtecertificaten, ${ }^{162}$ zoals bedoeld in artikel $2 \mathrm{I}$ van het Vlaamse Aardgasdecreet, toe te kennen. De mogelijkheid hiertoe is tot op heden nog niet verder uitgewerkt door de Vlaamse Regering. ${ }^{.63}$

\section{Samenwerking}

De onderscheiden decreten en ordonnanties verlenen de regulatoren de uitdrukkelijke bevoegdheid om met elkaar samen te werken, al verschillen de bewoordingen per gewest. Zo kan de VREG overgaan tot 'het sluiten van samenwerkingsovereenkomsten en het tot stand brengen van duurzame samenwerkingsverbanden, de zogenaamde partnerschapovereenkomsten met andere regulatoren

I56. Artikel 37, \$2 van het Vlaamse Elektriciteitsdecreet, zoals gewijzigd door het decreet van 7 mei 2004; artikel 39, \$2 van het Waalse Elektriciteitsdecreet (zie ook de verplichting van de CWaPE om elk jaar een jaarverslag op te maken over de evolutie van de markt van de groene certificaten. Dat verslag vermeldt o.a. het aantal groene certificaten toegekend per technologie en per energiebron in de loop van het in overweging genomen jaar, de groene certificaten overgemaakt aan de CWaPE, de gemiddelde prijs van een groen certificaat en de boetes opgelegd aan de netbeheerders en de leveranciers die de quota niet in acht zouden hebben genomen), en artikel $28, \$ 3$ van de Elektriciteitsordonnantie.

I57. Zie, voor wat de VREG betreft, ook T. Vermeir, 'Voorbestemdheid van het falen: groene energie in 2004' in K. Deketelaere (ed.), Jaarboek Energierecht 2004, Antwerpen, Intersentia, 2005, II7-II8, en T. Vermeir, 'Groene energie: u vraagt, wij draaien, de burgers betalen' in K. Deketelaere (ed.), Jaarboek Energierecht 2005-2006, Antwerpen, Intersentia, 2007, I96-I97.

158. Artikel 25 bis van het Vlaamse Elektriciteitsdecreet. De andere gewesten hebben geen zulke bijzondere bevorderingsmaatregelen. De Waalse en Brusselse procedures tot bevordering van de productie van groene stroom gelden tevens voor de WKK's.

I59. Artikel 5 van het Besluit van de Vlaamse Regering van 7 juli 2006 ter bevordering van de elektriciteitsopwekking in kwalitatieve warmtekrachtinstallaties, B.S. I december 2006. Zie ook artikel 7.I. 2 van het Vlaamse Energiedecreet. Vermeldenswaard is daarbij nog dat het Vlaamse Energiedecreet drie types van warmtekrachtcertificaten invoert.

I6o. Artikel II van het besluit van de Vlaamse Regering van 7 juli 2006 ter bevordering van de elektriciteitsopwekking in kwalitatieve warmtekrachtinstallaties, B.S. I december 2006. Zie ook artikel 7.I.II van het Energiedecreet.

I6r. Artikel 37, §2ter van het Vlaamse Elektriciteitsdecreet.

162. Dit zijn certificaten die aantonen dat een producent in een daarin aangegeven jaar een daarin opgegeven hoeveelheid groene warmte, uitgedrukt in kWh, heeft opgewekt.

I63. De andere gewesten hebben geen regeling inzake groenewarmtecertificaten uitgewerkt. 
en overheidsinstanties die werkzaam zijn op de Vlaamse en Europese elektriciteitsen aardgasmarkt'. ${ }^{64}$ De CWaPE heeft de bevoegdheid over te gaan tot 'la coopération et la concertation régulière avec les autres régulateurs des marchés [de l'électricité et du gaz], notamment en vue de vérifier l'absence de subsides croisés entre catégories de clients, ainsi qu'avec toute autre autorité ou organisme belge, étranger ou international'. ${ }^{165}$ De Elektriciteitsordonnantie staat BRUGEL toe om samen te werken 'met de gewestelijke, federale en Europese regulatoren van de elektriciteits- en de gasmarkt'. ${ }^{166}$

Daar waar de VREG en de CWaPE kunnen samenwerken met overheden en regulatoren, is de bevoegdheid van BRUGEL beperkt tot de samenwerking met andere regulatoren. Samenwerking met (andere) overheden dan de regulatoren is dan ook klaarblijkelijk niet mogelijk.

Samenwerking tussen de CWaPE en andere regulatoren voornamelijk dient te gebeuren met het oog op de controle van de afwezigheid van kruissubsidies tussen de verschillende categorieën van afnemers. De CWaPE kan bovendien samenwerkingsverbanden aangaan met 'internationale' regulatoren en overheden, in tegenstelling tot de andere regulatoren, wier bevoegdheden beperkt zijn tot Europese instanties. Het is de CWaPE aldus decretaal toegestaan om samen te werken met regulatoren en overheden die verantwoordelijk zijn voor elektriciteits- en gasmarkten buiten Europa.

Aanleg nieuwe directe lijnen en directe leidingen

De bevoegdheden van de regulatoren inzake de aanleg van nieuwe directe lijnen (voor elektriciteit) ${ }^{\mathrm{I} 67}$ en directe leidingen(voor aardgas) ${ }^{\mathrm{I} 68}$ is eveneens verschillend.

I64. Artikel $7, \S_{3}, \mathrm{IO}^{\circ}$ van het Oprichtingsdecreet. In het Vlaamse Energiedecreet wordt dit artikel 3.I. $4,8^{\circ}$.

I65. Artikel 43, §2, I $2^{\circ}$ van het Waalse Elektriciteitsdecreet en artikel 36 , §I, I $0^{\circ}$ van het Waalse Aardgasdecreet.

166. Artikel 3obis, $\S_{2}, 8^{\circ}$ van de Elektriciteitsordonnantie.

I67. Een directe lijn is gedefinieerd in het Vlaamse Elektriciteitsdecreet als 'elke elektrische leiding met een nominale spanning gelijk aan of lager dan $70 \mathrm{kV}$ die fysisch geen deel uitmaakt van het distributienet', in het Waalse Elektriciteitsdecreet als 'toute ligne d'électricité, d'une tension inférieure ou égale à 70 kilovolts ne faisant pas partie du réseau de transport local ou du réseau de distribution, qui, soit relie directement un producteur et un client final, soit relie directement un producteur à ses propres établissements et filiales, lorsque ce producteur n'est pas propriétaire de tous les terrains parcourus par cette ligne, en vue de leur approvisionnement' en in de Elektriciteitsordonnantie als een 'kabel of bovengrondse lijn die de punt tot punt verbinding verzekert tussen een producent en de eindafnemer'.

I68. Een directe leiding is gedefinieerd in het Vlaamse Aardgasdecreet als 'elke leiding voor aardgasdistributie die fysiek geen deel uitmaakt van het geïnterconnecteerd aardgasdistributienet', in het Waalse Aardgasdecreet als 'toute canalisation non reliée au réseau d'un gestionnaire de réseau, servant à la transmission de gaz naturel ou de gaz compatible qui, soit relie directement une entreprise de gaz autre qu'un gestionnaire de réseau, un fournisseur ou un intermédiaire, et un ou plusieurs clients, soit relie, en vue de leur approvisionnement, directement un producteur ou une entreprise de stockage à ses propres établissements et filiales, lorsque ce producteur ou cette entreprise de stockage n'est pas propriétaire de tous les terrains parcourus par la conduite', en in de Aardgasordonnantie als 'elke leiding die het gasvervoernet met een verbruikerslocatie verbindt en die fysiek geen deel uitmaakt van het distributienet'. 
Directe lijnen met een spanning gelijk aan of kleiner dan $70 \mathrm{kV}$ kunnen in het Brussels Hoofdstedelijk Gewest worden aangelegd mits de voorafgaande toekenning van een individuele vergunning door de bevoegde Minister. De criteria en de toekenningsprocedure voor die vergunningen moeten nog worden bepaald door de Brusselse Hoofdstedelijke Regering. ${ }^{169}$ Directe leidingen die geëxploiteerd worden bij een druk van 14,7 bar of minder kunnen worden geplaatst mits voorafgaande toekenning van een individuele vergunning door de Regering. De Regering bepaalt de toekenningsprocedure hiervoor. ${ }^{170}$ BRUGEL heeft de bevoegdheid tot het opstellen van de voorwaarden voor vergunningen die worden afgeleverd voor de aanleg van nieuwe directe lijnen en leidingen. ${ }^{17 \mathrm{I}}$ Wat deze bevoegdheid evenwel inhoudt, en hoe zich dit verhoudt met de principiële bevoegdheid van de regering om de criteria (voor de aanleg van directe lijnen) en de toekenningsprocedure voor de vergunningen te bepalen, is onduidelijk. De Regering is dus niet gebonden door de voorwaarden die BRUGEL zou vastleggen, en zou er in principe van kunnen afwijken.

De CWaPE oefent controle uit op de naleving van de voorwaarden opgenomen in de vergunningen die worden afgeleverd door de Waalse Regering voor de aanleg van nieuwe directe lijnen en leidingen die onder haar bevoegdheid vallen. ${ }^{12}$ Het Waalse Elektriciteitsdecreet noch het Waalse Aardgasdecreet bevatten enige bepaling in die zin. In respectievelijk het Waals Technisch Reglement Distributie Elektriciteit en het Waals Technisch Reglement Distributie Gas is gedeeltelijk een procedure uitgewerkt dat de CWaPE moet toelaten om een advies te verlenen aan de bevoegde minister. ${ }^{173}$ De Vlaamse regelgeving bepaalt dat de aanleg van directe lijnen en directe leidingen onderworpen is aan het bekomen van een voorafgaande toelating. ${ }^{174} \mathrm{De}$ nadere toepassingsregels, procedures en criteria zouden daarbij worden vastgelegd door de Vlaamse Regering. Op heden is dat evenwel nog niet gebeurd. ${ }^{175}$

Bemiddeling en beslechting van bepaalde geschillen en klachten

De regulatoren behartigen tevens de bemiddeling en de beslechting van bepaalde geschillen en klachten. Zo is de VREG gemachtigd om te bemiddelen bij geschillen

I69. Artikel 30 van de Elektriciteitsordonnantie. Zie ook T. Vermeir, 'Decentrale energieproductie en ecologische energieconsumptie’ in K. Deketelaere en B. Delvaux (eds.), Jaarboek energierecht 2008, Intersentia, 2009, III-II2.

I70. Artikel 22 Aardgasordonnantie.

I7I. Artikel 30 bis, $\$ 2,5^{\circ}$ van de Elektriciteitsordonnantie.

I72. Artikel 43, SI, $6^{\circ}$ van het Waalse Elektriciteitsdecreet en artikel 36, 6I, $6^{\circ}$ van het Waalse Aardgasdecreet.

173. Artikelen 27-3I van het Waals Technisch Reglement Distributie Elektriciteit en de artikelen 28-32 van het Waals Technisch Reglement Distributie Gas.

I74. Artikel I8 van het Vlaamse Elektriciteitsdecreet en artikel I7 van het Vlaamse Aardgasdecreet. Zie ook artikel 4.5.I van het Vlaamse Energiedecreet.

I75. Eind 2008 heeft de VREG weliswaar een nota gepubliceerd over decentrale energieproductie, m.n. de mededeling van 2 december 2008 'met betrekking tot de verplichtingen waaraan men moet voldoen bij de verkoop of levering in het Vlaamse Gewest van ter plaatse uit hernieuwbare energiebronnen of kwalitatieve warmtekrachtkoppeling opgewekte elektriciteit'. In deze nota worden enkele gevallen van directe lijnen/leidingen behandeld. Zie ook de bespreking hiervan door T. Vermeir, 'Decentrale energieproductie en ecologische energieconsumptie', in K. Deketelaere en B. Delvaux, Jaarboek Energierecht 2008, Antwerpen, Intersentia, 2008, I08-I3I. 
met betrekking tot de toegang tot het distributienet, de toepassing van de technische reglementen en de gedragscodes. Daarnaast is zij tevens bevoegd om geschillen te beslechten aangaande de toegang tot het distributienet. Dit betekent evenwel niet dat de VREG een burgerlijke rechtbank is. De VREG kan geen geschillen beslechten die betrekking hebben op burgerlijke rechten in de zin van artikel I44 van de Grondwet (contractuele rechten en verbintenissen). ${ }^{176}$ De VREG is evenmin een administratieve rechtbank.

BRUGEL is bevoegd voor het in ontvangst nemen en behandelen van klachten die verband houden met de openbaredienstverplichtingen op de Brusselse energiemarkten. ${ }^{177}$ Voor geschillen met betrekking tot de toegang tot het distributienet en/of de toepassing van de technisch reglementen in het Brussels Hoofdstedelijk Gewest, hebben de Elektriciteitsordonnantie en de Aardgasordonnantie in een bemiddelingsprocedure voorzien en een autonoom orgaan, de Geschillenkamer. ${ }^{178}$ Het secretariaat van de bemiddelingsprocedure en van de Geschillenkamer wordt georganiseerd door BRUGEL. ${ }^{179}$ Een aanvraag voor het inleiden van een bemiddelingsprocedure of een aanvraag voor het aanhangig maken van een zaak voor de Geschillenkamer gebeurt telkens bij verzoekschrift, gericht aan BRUGEL.

In de schoot van de CWaPE werd een Service régional de médiation opgericht, voor alle vragen en klachten met betrekking tot de werking van de Waalse gas- en elektriciteitsmarkt of met betrekking tot de activiteiten van een leverancier of netbeheerder, voor zover deze vraag of klacht behoort tot de gewestelijke bevoegdheid. ${ }^{80}$ Deze bemiddelingsinstantie oordeelt dus over een ruimer toepassingsgebied dan de VREG of de bemiddelaars in het Brussels Hoofdstedelijk Gewest. Daarnaast werd, eveneens in de schoot van de CWaPE, een Chambre des litiges ('geschillenkamer') opgericht. De CWaPE verzorgt het secretariaat van deze geschillenkamer. Het werkingsgebied van deze geschillenkamer is beperkter dan dat van de bemiddelingsinstantie, met name enkel de geschillen met betrekking tot de toegang tot het distributienet en de technische reglementen. ${ }^{\text {18I }}$ Ook hier zijn geschillen inzake

I76. Artikel 6, SI, $3^{\circ}$ van het Oprichtingsdecreet. Zie ook artikel 3.I.3, $3^{\circ}$ van het Vlaamse Energiedecreet.

177. Artikel 3obis, $\$ 2,6^{\circ}$ van de Elektriciteitsordonnantie.

I78. Artikel 23, \$§I-2 van de Elektriciteitsordonnantie en artikel I7, \$§I-2 van de Aardgasordonnantie. De nadere regels met betrekking tot de bemiddelingsprocedure en de geschillenkamer zijn uitgewerkt in het Besluit van de Brusselse Hoofdstedelijke Regering van 27 mei 2004 houdende organisatie van de bemiddelingsprocedure en de werking van de geschillenkamer bedoeld in artikel 23 van de ordonnantie van Ig juli 200 r betreffende de organisatie van de elektriciteitsmarkt in het Brussels Hoofdstedelijk Gewest en in artikel I7 van de ordonnantie van I april 2004 betreffende de organisatie van de gasmarkt in het Brussels Hoofdstedelijk Gewest, betreffende de wegenisretributies inzake gas en elektriciteit en houdende wijziging van de ordonnantie van I9 juli 200I betreffende de organisatie van de elektriciteitsmarkt in het Brussels Hoofdstedelijk Gewest, B.S. 28 juni 2004.

I79. Artikel 23, \$3 van de Elektriciteitsordonnantie en artikel I7, \$3 van de Aardgasordonnantie.

I80. Artikel 48, SI van het Waalse Elektriciteitsdecreet. Hoewel de bemiddelingsinstantie actief is voor de bemiddeling van geschillen die betrekking hebben op zowel de Waalse gas- en elektriciteitsmarkt, is deze taak enkel ingeschreven in het Waalse Elektriciteitsdecreet.

I8I. Artikelen 49 en 49 bis van het Waalse Elektriciteitsdecreet. 
burgerlijke rechten uitgesloten. De geschillenkamer doet uitspraak aan de hand van gemotiveerde administratieve beslissingen. Bij hoogdringendheid kan de geschillenkamer zelfs bewarende maatregelen opleggen. Het Waalse Elektriciteitsdecreet voorziet wel in een specifiek georganiseerd hoger beroep tegen de beslissingen van deze geschillenkamer bij het Hof van Beroep te Luik, zetelend zoals in kort geding.

\section{Algemene informerende taken}

De regulatoren vervullen tenslotte nog algemene informerende taken. De VREG heeft een algemene informerende functie, met name het informeren van de marktactoren en de verbruikers over de werking van de elektriciteits- en aardgasmarkten, en het informeren van de verbruikers over de prijzen en voorwaarden van de leveranciers, inbegrepen een objectieve vergelijking van deze prijzen en voorwaarden. ${ }^{182}$ Deze bepaling biedt een duidelijke decretale basis voor de vergelijking tussen de leveranciers die de VREG reeds geruime tijd op haar website publiceert. ${ }^{183} \mathrm{De}$ VREG publiceert dienaangaande ook jaarlijkse marktrapporten en jaarverslagen. Het Vlaamse Energiedecreet maakt de VREG nog bijkomend uitdrukkelijk bevoegd voor 'het opstellen en publiceren van statistieken en gegevens met betrekking tot de elektriciteits- en gasmarkt', ${ }^{84}$ iets wat de VREG vroeger ook al deed.

De CWaPE beschikt, evenmin als BRUGEL trouwens, over een algemene informerende taak. De CWaPE is wel bevoegd om alle nodige uit te voeren studies teneinde de werking van de elektriciteits- en de gasmarkt te verbeteren, de uitoefening van de afnemer van zijn leverancierskeuze te vereenvoudigen en de overheid te informeren over de marktactoren en de afnemers. ${ }^{185}$ Daarnaast is de CWaPE verplicht om jaarlijks een verslag op te stellen over de uitvoering van haar verplichtingen en de evolutie van de elektriciteits- en gasmarkt. De bevoegde Minister maakt dit rapport over aan het Waalse parlement, en ziet toe op de publicatie ervan. ${ }^{186}$

BRUGELs bijzondere informerende bevoegdheden staan verspreid in de Elektriciteitsordonnantie. Zo kan zij, op eigen initiatief dan wel op vraag van de bevoegde minister of de Brusselse Hoofdstedelijke regering, onderzoeken en studies van de elektriciteits- en de gasmarkt laten uitvoeren. ${ }^{87}$ Daarnaast maakt zij, net zoals de CWaPE, jaarlijks een verslag op over de uitvoering van haar verplichtingen en de evolutie van de elektriciteits- en gasmarkt, alsook over de naleving van de openbaredienstverplichtingen door de distributienetbeheerder en de leveranciers, in het bijzonder in het domein van de rechten van de huishoudelijke gebruikers. ${ }^{\text {}} 88$

I82. Artikel 6, SI, $4^{\circ}$ van het Oprichtingsdecreet. Zie ook artikel 3.I.3, $4^{\circ}$, a) en b) van het Vlaamse Energiedecreet.

I83. K. Deketelaere (ed.), Handboek Milieu- en Energierecht, Brugge, die Keure, 2006, IIo8.

I84. Artikel 3.I.3., $4^{\circ}$, c) van het Vlaamse Energiedecreet.

I85. Artikel 43, $\S_{2}, \mathrm{I}_{3}^{\circ}$ van het Waalse Elektriciteitsdecreet en artikel $36, \S_{\mathrm{I}}, \mathrm{II}^{\circ}$ van het Waalse Aardgasdecreet.

I86. Artikel 43, \$3 van het Waalse Elektriciteitsdecreet en artikel 36, \$2 van het Waalse Aardgasdecreet.

I87. Artikel 3obis, $\$ 2,2^{\circ}$ van de Elektriciteitsordonnantie.

I88. Artikel 3obis, $\$ 2,9^{\circ}$ van de Elektriciteitsordonnantie. 
De publicatie van het verslag wordt verzorgd door de Brusselse Hoofdstedelijke Regering. Tenslotte is BRUGEL verantwoordelijk voor het ter beschikking stellen aan de afnemers van instrumenten voor informatie over de situatie van de elektriciteitsmark $\mathrm{t}^{189}$ en de bepalingen van de Elektriciteitsordonnantie, op basis van de informatie die periodiek aan de leveranciers en distributienetbeheerders wordt gevraagd. ${ }^{190}$

\section{Derde pakket energiewetgeving - impact op de regulatoren}

\section{I Algemeen}

De voorbije jaren hebben de instellingen van de Europese Unie waaronder de Commissie, het Europees Parlement en de Raad diverse onderhandelingen gevoerd met betrekking tot het derde wetgevende pakket dat op I9 september 2007 door de Commissie werd voorgesteld. ${ }^{19 I}$ Dit pakket voorziet in wijzigingen aan de bestaande Tweede Elektriciteits- en Tweede Gasrichtlijnen, alsook de Elektriciteits-Gasverordening. ${ }^{192}$ Tevens bevat het pakket een voorstel van Verordening van het Europees Parlement en de Raad tot oprichting van een Agentschap voor de samenwerking tussen energieregelgevers. ${ }^{193}$

Op 2I april 2009 keurde het Europese Parlement in een tweede lezing dit derde wetgevende pakket goed en werden na de finale goedkeuring op de Raad, de volgende richtlijnen en verordeningen afgekondigd in het Publicatieblad:

(a) Richtlijn 2009/72/EG van het Europees Parlement en de Raad van I3 juli 2009 betreffende gemeenschappelijke regels voor de interne markt voor elektriciteit en tot intrekking van Richtlijn 2003/54/EG; ${ }^{194}$

(b) Richtlijn 2009/73/EG van het Europees Parlement en de Raad van I3 juli 2009 betreffende gemeenschappelijke regels voor de interne markt voor aardgas en tot intrekking van Richtlijn 2003/55/EG; ${ }^{195}$

I89. De Aardgasordonnantie bevat geen dergelijke gelijkaardige verplichting voor de aardgasmarkt. I9o. Artikel zobis, \$2, $3_{3}^{\circ}$ van de Elektriciteitsordonnantie.

I9I. Zie www.ec.europa.eu/energy/gas_electricity/third_legislative_package_en.htm.

192. Voorstel van richtlijn tot wijziging van Richtlijn 2003/54/EG betreffende gemeenschappelijke regels voor de interne markt voor elektriciteit, COM(2007) 528 (hierna Ontwerprichtlijn Elektriciteit); Voorstel van richtlijn tot wijziging van Richtlijn 2003/55/EG betreffende de gemeenschappelijke regels voor de interne markt voor gas, COM(2007)529 (hierna Ontwerprichtlijn Gas), Voorstel van verordening tot wijziging van Verordening (EG) nr. I228/2003 betreffende de voorwaarden voor toegang tot het net voor grensoverschrijdende handel in elektriciteit COM(2007)53I (hierna Ontwerpverordening Elektriciteit), Voorstel van verordening tot wijziging van Verordening (EG) nr. I775/2005 betreffende de voorwaarden voor de toegang tot de aardgastransmissienetten, $\operatorname{COM(2007)} 532$ (hierna Ontwerpverordening Gas).

193. COM(2007)530 (hierna Voorstel van verordening tot oprichting van het Agentschap) en T. Vanden Borre, 'Derde pakket voor de vrijmaking van de elektriciteitsmarkt: Quo Vadis?' in 'Het Europese Energie- en Klimaatpakket', K. Deketelaere en B. Delvaux (ed), Milieu- en Energierecht 2008-3, p. I82-I94.

I94. PB nr. L 2II van I4 augustus 2009 (hierna: Elektriciteitsrichtlijn 2009/72/EG).

195. PB nr. L 2II van I4 augustus 2009 (hierna: Gasrichtlijn 2009/73/EG). 
(c) Verordening (EG) nr. 713/2009 van het Europees Parlement en de Raad van I3 juli 2009 tot oprichting van een Agentschap voor de samenwerking tussen energieregulators; ${ }^{196}$

(d) Verordening (EG) nr. 714/2009 van het Europees Parlement en de Raad van I3 juli 2009 betreffende de voorwaarden voor toegang tot het net voor grensoverschrijdende handel in elektriciteit en tot intrekking van Verordening (EG) nr. $1228 / 2003^{197}$ en

(e) Verordening (EG) nr. 715/2009 van het Europees Parlement en de Raad van I3 juli 2009 betreffende de voorwaarden voor de toegang tot aardgastransmissienetten en tot intrekking van Verordening (EG) nr. $1775 / 2005 \cdot 198$

De opzet van dit onderdeel is kort stil te staan met de recente ontwikkelingen die relevant zijn voor het onderwerp van deze bijdrage. De auteurs beogen geenszins een volledig overzicht te geven van de diverse wijzigingen aan de elektriciteits- en gaswetgeving op Europees niveau en hun impact voor de Belgische wetgeving. ${ }^{199}$

\subsection{Wijzigingen}

\subsubsection{Wijzigingen met betrekking tot de regulatoren}

Op grond van de Tweede Elektriciteits- en de Tweede Aardgasrichtlijn dienen de lidstaten nationale regulatoren aan te wijzen met specifieke bevoegdheden. Uit de toepassing van deze bepalingen in de praktijk is gebleken dat in sommige lidstaten, in tegenstelling tot andere, de bevoegdheden van deze regulatoren beperkt zijn gebleven of verdeeld werden over diverse instanties, belemmerd werden door een onvoldoende onafhankelijkheid ten aanzien van regeringen. Om hieraan tegemoet te komen voorzien de artikelen 35 tot en met 40 van de Elektriciteitsrichtlijn 2009/72/EG en de artikelen 39 tot en met 44 van de Gasrichtlijn 2009/73/EG in een uitbreiding van de bevoegdheden van de regelgevende instantie en een versterking van de onafhankelijkheid van de nationale regulerende instanties.

Deze onafhankelijkheid moet volgens beide richtlijnen door de lidstaten worden gewaarborgd. Bovendien dienen zij ervoor te zorgen dat de regulerende instanties op onpartijdige en transparante wijze hun bevoegdheden kunnen uitoefenen. Hiertoe stellen beide richtlijnen voorop dat de regulerende instanties juridisch gescheiden en functioneel onafhankelijk dienen te zijn van enige publieke of particuliere

I96. PB nr. L 2II van I4 augustus 2009 (hierna: Verordening tot oprichting van het Agentschap 7I3/2009).

I97. PB nr. L 2II van I4 augustus 2009 (hierna: Elektriciteitsverordening 7I4/2009).

I98. PB nr. L 2II van I4 augustus 2009 (hierna: Gasverordening 715/2009).

I99. Voor bijkomende informatie zie B. Delvaux, 'Recente ontwikkelingen in het Europees energierecht en -beleid - Is de Sagradia Familia eindelijk af?' in K. Deketelaere en B. Delvaux (ed.), Jaarboek Energierecht 2007, Antwerpen, Intersentia, 2008, p. I-33 en B. Delvaux en T. Vanden Borre, 'Recente ontwikkelingen in het Europese Energierecht en -beleid - Heel wat lekkers in de Europese pijplijn' in K. Deketelaere en B. Delvaux (ed.), Jaarboek Energierecht 2008, Antwerpen, Intersentia, 2009, p. I-44. 
entiteit. Daarnaast dient haar personeel en de personen die belast zijn met haar beheer onafhankelijk te zijn van marktbelangen en bij het verrichten van reguleringstaken geen directe instructies te verlangen of ontvangen van regeringen of andere publieke of particuliere entiteiten.

Om de onafhankelijkheid van de regulerende instanties te beschermen is het de taak van de lidstaten om er tevens over te waken dat de regulerende instanties zelfstandig besluiten kunnen nemen, onafhankelijk zijn van enig politiek orgaan, een afzonderlijke jaarlijkse begrotingstoewijzing ontvangen, zodat zij over de nodige autonomie beschikken bij de uitvoering van de toegewezen begroting, alsook over adequate personele en financiële middelen opdat zij haar taken kan uitvoeren. Daarnaast dienen de leden van het bestuur, of bij afwezigheid hiervan de hogere leiding, van de regulerende instantie te worden aangesteld voor een vaste termijn van vijf tot zeven jaar, die eenmaal kan worden verlengd. Noteer dat de leden van het bestuur of de hogere leiding voortaan volgens de bepalingen van beide richtlijnen enkel uit hun ambt kunnen worden ontheven als ze niet meer voldoen aan de voorwaarden van artikel 35 van de Elektriciteitsrichtlijn 2009/72/EG en het artikel 39 van de Gasrichtlijn 2009/73/EG of volgens de nationale wetgeving zich schuldig hebben gemaakt aan wangedrag.

Vervolgens voorzien artikel 36 van de Elektriciteitsrichtlijn 2009/72/EG en artikel 40 van de Gasrichtlijn 2009/73/EG in de doelstellingen van de regulerende instanties. Deze doelstellingen hebben ondermeer betrekking op: (a) de bevordering, in nauwe samenwerking met het Agentschap, de regulerende instanties van andere lidstaten en de Commissie, van een door concurrentie gekenmerkte, zekere en vanuit milieuoogpunt duurzame interne markt voor elektriciteit en gas binnen de Gemeenschap en van een daadwerkelijke openstelling van de markt voor alle afnemers en leveranciers in de Gemeenschap, en waarborging dat elektriciteitsnetten en gasnetten op een doeltreffende en betrouwbare manier werken, rekening houdend met doelstellingen op lange termijn; (b) de ontwikkeling van door concurrentie gekenmerkte en goed functionerende regionale markten binnen de Gemeenschap met het oog op het bereiken van de onder (a) genoemde doelstelling; (c) het opheffen van alle beperkingen voor handel in elektriciteit en gas tussen de lidstaten, inclusief de ontwikkeling van afdoende grensoverschrijdende transmissiecapaciteit om aan de vraag te voldoen en de integratie van nationale markten te versterken, hetgeen de elektriciteitsstromen en gasstromen in de Gemeenschap kan faciliteren; [...]; (g) het waarborgen van de afnemers hun baten bij een efficiënte werking van hun nationale markt, bevorderen van daadwerkelijke mededinging en bijdragen tot het waarborgen van consumentenbescherming; [...]. ${ }^{200}$

Naast deze algemene doelstellingen voorzien artikel 37 van de Elektriciteitsrichtlijn 2009/72/EG en artikel 4I van de Gasrichtlijn 2009/73/EG in diverse taken en

200. Voor een volledig overzicht van deze algemene doelstellingen van de regulerende instanties zie artikel 36 van de Elektriciteitsrichtlijn 2009/72/EG en artikel 40 van de Gasrichtlijn 2009/73/EG. 
bevoegdheden die de lidstaten dienen toe te wijzen aan de nationale regulerende instanties. Deze taken en bevoegdheden omvatten onder meer:

a) het vaststellen of goedkeuren, volgens transparante criteria, van transmissie- of distributietarieven of de berekeningsmethodes hiervoor; ${ }^{201}$

b) ervoor te zorgen dat transmissie- en distributiesysteembeheerders, en in voorkomend geval, de betrokken systeemeigenaars alsmede alle elektriciteitsbedrijven hun verplichtingen uit hoofde van de Elektriciteitsrichtlijn 2009/72/EG en de Gasrichtlijn 2009/73/EG en de andere toepasselijke communautaire wetgeving naleven, inclusief bij grensoverschrijdende kwesties;

c) samenwerken in verband met grensoverschrijdende kwesties met de regulerende instanties of instanties van de betrokken lidstaten en met het Agentschap;

d) naleven en uitvoeren van alle relevante wettelijke bindende besluiten van het Agentschap en de Commissie;

e) op jaarlijkse basis verslag uitbrengen over haar activiteit en de uitvoering van haar taken aan de betrokken autoriteiten van de lidstaten, het Agentschap en de Commissie. Dit verslag dient de genomen maatregelen en behaalde resultaten voor elk van haar taken te behandelen;

f) erover waken dat er geen kruissubsidies zijn tussen activiteiten met betrekking tot transmissie, distributie en levering;

g) $[\ldots .$.$] .$

Opdat de regulerende instanties de hierboven vermelde taken en bevoegdheden op een efficiënte en snelle wijze kunnen uitoefenen voorzien beide richtlijnen dat zij: (a) bindende besluiten kunnen nemen ten aanzien van elektriciteits- en gasbedrijven; (b) onderzoeken kunnen uitvoeren naar de werking van de elektriciteits- en gasmarkten en besluiten tot, en opleggen van, noodzakelijke en evenredige maatregelen om daadwerkelijke mededinging te bevorderen en de goede werking van de markt te waarborgen; (c) bij elektriciteits- en gasbedrijven informatie opvragen die relevant is voor de uivoering van haar taken; (d) effectieve, evenredige en afschrikkende sancties opleggen aan elektriciteits- en gas bedrijven die hun verplichtingen uit hoofde van beide richtlijnen of enig toepasselijk bindend wettelijk besluit van de regulerende instantie of het Agentschap niet naleven, of een bevoegde rechtbank voorstellen dergelijke sancties op te leggen en (e) over passende bevoegdheden beschikken om onderzoek uit te voeren en over de nodige onderzoeksbevoegdheden beschikken met het oog op een geschillenbeslechting. Tenslotte, voorzien de overige artikelen in het kader van de regulerende instanties in een reguleringsstelsel voor grensoverschrijdende kwesties, de naleving van richtsnoeren door de regulerende instantie en aantal bepalingen die voorzien in een verplichting om welbepaalde gegevens ter beschikking te houden. ${ }^{202}$

20I. Zie ook lid 6 van artikel 37 van de Elektriciteitsrichtlijn 2009/72/EG en lid 6 van artikel 4I van de Gasrichtlijn 2009/73/EG.

202. Zie lid 4 van artikel 37 van de Elektriciteitsrichtlijn 2009/72/EG en lid 4 van artikel 4I van de Gasrichtlijn 2009/73/EG. 
Het voorgaande en de desbetreffende bepalingen in de Elektriciteitsrichtlijn 2009/72/EG en Gasrichtlijn 2009/73/EG geven duidelijk weer dat men er op Europees niveau ervoor geopteerd heeft om het takenpakket van de nationale regulerende instanties aan de hand van dergelijke gedetailleerde opsomming volledig te stroomlijnen tussen de verschillende lidstaten.

\subsubsection{Wijzigingen inzake consumentenbescherming}

De Elektriciteitsrichtlijn 2009/72/EG en Gasrichtlijn 2009/73/EG verlenen de regulatoren bijkomende taken inzake consumentenbescherming: de regulatoren dienen, samen met andere betrokken instanties, te 'helpen waarborgen' dat verschillende maatregelen ter bescherming van de consument 'doeltreffend zijn en gehandhaafd worden'. ${ }^{203}$

Deze maatregelen zijn opgesomd in bijlage I 'Voorschriften inzake consumentenbescherming' van de Elektriciteitsrichtlijn 2009/72/EG en de Aardgasrichtlijn 2009/73/EG. Zij zijn van toepassing op 'afnemers' in het algemeen - volgens artikel 3 , zevende lid van richtlijn 2009/72/EG, en artikel 3, derde lid van richtlijn 2009/73/ $\mathrm{EG},{ }^{204}$ ten minste voor wat huishoudelijke afnemers betreft. De bijlage bepaalt dat 'afnemers':

- Recht hebben op een contract met hun leverancier. In dit contract dienen bepaalde gegevens, zoals de geleverde diensten en aangeboden onderhoudsdiensten, het kwaliteitsniveau, informatie over consumentenrechten, duur van het contract, voorwaarden voor verlenging en beëindiging, vergoedingen en terugbetalingsdiensten etc. te worden opgenomen. De contractuele voorwaarden moeten eerlijk zijn en vooraf bekend. Deze informatie moet voorafgaand aan de ondertekening of de bevestiging van het contract worden verstrekt.

- Op toereikende wijze in kennis moeten worden gesteld van ieder voornemen de contractvoorwaarden te wijzigen. De afnemers hebben daarop het recht het contract op te zeggen wanneer zij van een dergelijk voornemen in kennis worden gesteld. Tariefstijgingen moeten binnen een redelijke termijn op transparante en begrijpelijke wijze worden meegedeeld. De afnemers moeten dan de mogelijkheid krijgen contracten op te zeggen indien zij de hun door de leverancier aangemelde nieuwe voorwaarden niet aanvaarden.

- Transparante informatie ontvangen over geldende prijzen, tarieven en standaardvoorwaarden met betrekking tot de toegang tot en het gebruik van diensten.

- Zonder discriminatie, een ruime keuze van betalingswijzen wordt aangeboden.

- Geen kosten in rekening worden gebracht indien zij van leverancier veranderen.

203. Zie artikel 37, lid I, (n) van de Elektriciteitsrichtlijn 2009/72/EG en lid 4 van artikel 4I, lid I, (o) van de Gasrichtlijn 2009/73/EG.

204. Het artikel 3 , derde lid verwijst naar een bijlage A, die evenwel niet werd opgenomen bij de richtlijn. Waarschijnlijk wordt dan ook 'bijlage I' bedoeld. 
- Een transparant, eenvoudig en goedkoop systeem van buitengerechtelijke klachtenbehandeling ter beschikking wordt gesteld.

- Voor elektriciteit, in kennis worden gesteld van hun rechten inzake universele dienstverlening, zoals bepaald in artikel 3, lid 3 van Elektriciteitsrichtlijn 2009/72/EG, dat wil zeggen het recht op levering van elektriciteit van een bepaalde kwaliteit tegen redelijke, eenvoudig en duidelijk vergelijkbare, doorzichtige en niet-discriminerende prijzen op hun grondgebied, voor zover zij toegang hiertoe hebben; voor aardgas werd bepaald dat de afnemers die op het gassysteem zijn aangesloten, in kennis worden gesteld van hun recht om te worden voorzien in aardgas van een bepaalde kwaliteit tegen een redelijke prijs.

- Beschikking krijgen over hun verbruiksgegevens, ter beschikking krijgen zonder extra kosten. ${ }^{205}$

- Naar behoren en voldoende frequent geïnformeerd worden over hun daadwerkelijk verbruik en de kosten daarvan.

- Ten laatste zes weken na verandering van de leverancier in kennis worden gesteld van een definitieve afsluitingsrekening.

Daarnaast dienen de lidstaten ervoor te zorgen dat een systeem van slimme meters wordt ingevoerd. De invoering van dergelijk systeem kan worden onderworpen aan een economische kosten-baten evaluatie. ${ }^{206}$

In functie van hun respectieve bevoegdheden, zullen de federale wetgever, de regionale decreetgevers en de ordonnantiegever in België de bepalingen van deze richtlijnen moeten omzetten. Het valt af te wachten welke bevoegdheden zij aan de regulatoren zullen geven om 'te helpen waarborgen' dat bovenstaande maatregelen 'doeltreffend zijn en gehandhaafd worden'. Alleszins zullen de bestaande taken niet volstaan om de nieuwe bevoegdheden die deze richtlijnen de regulatoren bieden, te omvatten. Verschillende vormen kunnen zich aandienen. Bijvoorbeeld:

- 'brievenbus'-functie, waarbij de regulator de consument-rechtzoekende doorwijst naar de bevoegde instantie, of adviseert al dan niet een juridische procedure voor de hoven en rechtbanken op te starten.

- Via steekproeven toezicht houden op de contracten en contractuele praktijken van de leveranciers, en overtredingen bestraffen met administratieve geldboetes.

- In eigen naam en uit kracht van de wet, het aanhangig maken van geschillen voor de verschillende Hoven en Rechtbanken. De regulator is immers zelf geen

205. Voor de verstrekking van deze informatie wordt een voldoende ruime termijn ingesteld, waarbij rekening wordt gehouden met de capaciteit van de meetapparatuur van de afnemer. Inzake elektriciteit wordt bijkomend rekening gehouden met het elektriciteitsproduct in kwestie.

206. Onder voorbehoud van deze evaluatie, stellen de lidstaten, of de bevoegde autoriteit die zij aanwijzen, vervolgens een tijdschema op voor de invoering van dergelijke slimme metersystemen. Voor elektriciteit werd bijkomend nog bepaald dat dergelijk tijdschema maximaal tien jaar mag bedragen. Indien de ingebruikname van slimme meters voor elektriciteit positief wordt beoordeeld, wordt uiterlijk in 2020 minstens $80 \%$ van de consumenten voorzien van deze slimme metersystemen. 
rechtsprekende instantie, en kan dus geen contractuele geschillen tussen afnemer en leverancier beslechten.

- Uitwerken en verplicht opleggen van een modelcontract/kaderovereenkomst tussen afnemers en leveranciers.

Daarbij zal een en ander waarschijnlijk ook rekening moeten houden met de bestaande (federale) bepalingen inzake consumentenbescherming van de WHPC.

\subsection{Derde pakket - gevolgen voor de regulatoren \& reflectie}

Het derde pakket voorziet nu uitdrukkelijk in de mogelijkheid om eigen gewestelijke regulatoren in het leven te kunnen roepen. Nochtans kan elke lidstaat slechts één vertegenwoordiger op gemeenschapsniveau aanduiden binnen de Raad van Bestuur van het op Europees niveau op te richten Agentschap.

Zoals hierboven werd vermeld dienen de regulatoren juridisch en functioneel volledig onafhankelijk te worden van andere publieke of private entiteiten. Dit betekent echter niet dat de regulatoren niet meer zouden kunnen samenwerken met andere overheidsinstanties, of dat algemene beleidsrichtsnoeren van de overheid, niet meer zouden kunnen worden toegepast. ${ }^{207}$

Om deze onafhankelijkheid te versterken, voorziet het derde pakket dat regulatoren zelfstandig beslissingen moeten kunnen treffen, onafhankelijk van enig politiek orgaan, met een eigen gescheiden jaarlijkse begroting. De regulatoren moeten de middelen van deze begroting zelf kunnen inzetten naar eigen inzichten. De regulatoren moeten tevens over voldoende financiële en menselijke middelen kunnen beschikken om hun taken te kunnen uitoefenen. Het bestaande toezicht door de gewestelijke en federale regeringen op de regulatoren zal zodoende moeten verminderen, opdat de regulatoren werkelijk onafhankelijke toezichthouders in de zin van Elektriciteitsrichtlijn 2009/72/EG en Aardgasrichtlijn 2009/73/EG zouden kunnen zijn.

Nochtans is het aanbevelenswaardig om enige vorm van toezicht op de regulatoren te behouden, het motto 'Qui(s) custodiet ipsos custodes' ${ }^{208}$ indachtig. Het derde pakket sluit dergelijk toezicht ook niet uit. Een verkozen instelling van volksvertegenwoordigers zou toezicht kunnen uitoefenen op de activiteiten van een regulerende instantie. Dergelijke controle kan best worden uitgeoefend via het (bestaande) systeem van publicatie van jaarverslagen, rapporten en verslagen. Er kan hierbij nog worden gedacht aan hoorzittingen en verantwoordingen naar de uitvoering van de taken en besteding van de financiën door de regulatoren. Dergelijk toezicht betekent niet dat de beslissingen van de regulator onaanvechtbaar zouden zijn. Zij

207. Artikel 35, lid 4 van Elektriciteitsrichtlijn 2009/72/EG en artikel 39, lid 4 van Aardgasrichtlijn 2009/73/EG.

208. 'Wie bewaakt de bewakers' - satiren van Juvenalis. 
moeten voor een onafhankelijke gerechtelijke instantie kunnen worden nagegaan op hun legaliteit en afstemming met de toepasselijke wetten en decreten/ordonnanties, in acht genomen alle rechten van verdediging en vertegenwoordiging. Dergelijk beroep bij de rechterlijke macht dient evenwel te worden georganiseerd aan de hand van duidelijk afgebakende bevoegdheden in hoofde van de rechterlijke macht.

Voor wat betreft de huidige structuur en werking van de gewestelijke regulatoren, kan bij de omzetting van het derde pakket aan maatregelen in het kort dan ook reeds op volgende mogelijke knelpunten worden gewezen:

- BRUGELs opdrachthouders vervullen opdrachten van BRUGEL en werken weliswaar onder haar gezag, maar blijven personeelsleden van BIM. Los van de vraag naar de toepassing van de wetgeving inzake de terbeschikkingstelling van personeel, lijkt dit systeem niet te voldoen aan de regels van het derde pakket inzake onafhankelijkheid. De opdrachthouders zijn immers niet functioneel onafhankelijk van het BIM, dat een overheidsinstantie is. Daarbij komt nog dat BRUGEL op heden geen permanente instelling is.

- Onafhankelijkheid impliceert ook dat de regulator zelfstandig rechtsgedingen in eigen naam en voor eigen rekening moet kunnen voeren. De Elektriciteitsordonnantie zal terdege moeten worden aangepast, aangezien BRUGEL op heden slechts 'ten verzoeke van' BIM kan optreden in rechte.

- Het systeem van actieve tussenkomst van de regeringscommissarissen in de werking en beraadslaging van de regulatoren, alsook de beroepsprocedure, komen eveneens op de helling te staan.

- Men kan zich tevens de vraag stellen of de regering en/of het parlement beslissingen van de regulator nog kunnen goed- of afkeuren, zo bijvoorbeeld de goedkeuring van de technische reglementen, de tarieven, het huishoudelijk reglement en de vergunningen van de leveranciers en de netbeheerders, te verlenen door de regulator.

Wat de onafhankelijkheid van de regulatoren betreft is het onduidelijk in welke mate de federale of gewestelijke regeringen of andere publieke entiteiten in de praktijk aan de federale regulator of de gewestelijke regulatoren geen directe instructies meer zullen verlenen. Aangezien het mandaat van de leden van het bestuur, of bij afwezigheid hiervan de hogere leiding, van de regulerende instantie volgens beide richtlijnen eenmaal kan verlengd worden is het zeer de vraag of deze leidinggevende personen met het oog op een verlenging van hun mandaat al dan niet in de verleiding zullen komen om toch welbepaalde instructies toe te passen. Het is bovendien onduidelijk hoe men in de praktijk zal kunnen controleren of een regulerende instantie bij het nemen van een beslissing instructies heeft verkregen. Hierdoor zal het succes van de onafhankelijkheid van de regulerende instanties in belangrijke mate afhangen van de wijze waarop de betrokken partijen (bevoegde minister van energie, regering, het bevoegde ministerie, de leidinggevende partijen van de regulerende instantie, enz.) de voorgeschreven bepalingen van beide richtlijnen in dit kader zullen hanteren in de praktijk. 
De bevoegdheden van de regulatoren worden tevens uitgebreid. Zo maakt het derde pakket de regulatoren onder andere bevoegd om bindende beslissingen te nemen ten aanzien van gas- en/of elektriciteitsbedrijven. ${ }^{209}$ Dit konden de regulatoren in het verleden reeds gedeeltelijk (bv. de VREG is bevoegd om leveringsvergunningen voor gas- en/of elektriciteit af te leveren; de regulatoren kunnen verschillende administratieve geldboeten opleggen), maar de huidige regeling lijkt veel ruimer te kunnen gaan. Zo zouden de regulatoren gas- en elektriciteitsbedrijven kunnen verplichten om de regels van de respectieve gas- en elektriciteitswetgeving daadwerkelijk na te leven. De tanden van de regulator lijken dus te worden gescherpt.

De vraag die zich daarbij stelt is hoe deze dwingende beslissingen kunnen worden afgedwongen. Het derde pakket bepaalt dat de regulatoren 'effectieve, evenredige en afschrikkende sancties' aan elektriciteits- en/of aardgasbedrijven kunnen opleggen die hun verplichtingen uit hoofde van het derde pakket of een enig toepasselijk wettelijk bindend besluit van de regulator niet naleven. Eventueel kunnen zij een rechtbank verzoeken om deze boeten ten uitvoer te doen leggen. ${ }^{210}$ Deze bijkomende bevoegdheid voor de regulatoren om de naleving van de verplichtingen in het kader van het derde pakket of enig toepasselijk wettelijk bindend besluit van hun of het Agentschap te doen naleven is een welgekomen wijziging en zal de slagkracht van de regulatoren in belangrijke mate versterken.

Het derde pakket bevat daarnaast nog bijzondere maatregelen inzake bescherming van de afnemers, onder andere op het vlak van de contractuele bepalingen met een leverancier van elektriciteit of gas. ${ }^{2 I I}$ De regulatoren worden ook uitdrukkelijk bevoegd om toezicht te houden op 'restrictieve contractuele praktijken'. Hieronder worden onder andere begrepen 'exclusiviteitsbepalingen, die grote niet-huishoudelijke afnemers kunnen weerhouden van of hen beperkingen kunnen opleggen met betrekking tot een keuze voor het gelijktijdig sluiten van overeenkomsten met meer dan één leverancier'. Indien noodzakelijk zullen de regulatoren de nationale mededingingsautoriteiten van dergelijke praktijken op de hoogte brengen. ${ }^{212}$ In het derde pakket is daarbij enkel sprake van clausules die de rechten op samenaankoop van 'niet-huishoudelijke afnemers' beperken. De regulator is enkel bevoegd om toezicht

209. Artikel 37, lid 4, (a) van Elektriciteitsrichtlijn 2009/72/EG en artikel 4I, lid 4, (a) van Aardgasrichtlijn 2009/73/EG. Een elektriciteitsbedrijf is zeer ruim gedefinieerd als 'elke natuurlijke persoon of rechtspersoon die ten minste een van de volgende functies vervult: productie, transmissie, distributie, levering of aankoop van elektriciteit, en die verantwoordelijk is voor de met deze functies verband houdende commerciële, technische of onderhoudswerkzaamheden, maar die geen eindafnemer is'; een aardgasbedrijf is een 'natuurlijke persoon of rechtspersoon die ten minste een van de volgende functies vervult: productie, transmissie, distributie, levering, aankoop of opslag van aardgas, met inbegrip van LNG, en die verantwoordelijk is voor de met deze functies verband houdende commerciële, technische en/of onderhoudswerkzaamheden, maar die geen eindafnemer is'.

210. Artikel 37, lid 4, (d) van Elektriciteitsrichtlijn 2009/72/EG en artikel 4I, lid 4, (d) van Aardgasrichtlijn 2009/73/EG.

2II. Bijlage I bij Elektriciteitsrichtlijn 2009/72/EG en bijlage I bij Aardgasrichtlijn 2009/73/EG.

2I2. Artikel 37, lid I (k) van Elektriciteitsrichtlijn 2009/72/EG en artikel 4I, lid I (k) van Aardgasrichtlijn 2009/73/EG. 
te houden op 'praktijken', en kan dus klaarblijkelijk niet ingrijpen in de contractuele verhoudingen, zodra de overeenkomsten werden gesloten, zelf. Eens de overeenkomst geldig werd gesloten, wordt aan de autonomie en de bindende kracht ervan niet meer getornd door de regulator. De bindende kracht van overeenkomsten en de contractvrijheid blijven dan ook gerespecteerd.

Aangezien de tekst spreekt van contractuele 'practices', - praktijken - 'bij niet-huishoudelijke afnemers' lijken consumenten hier niet onder te kunnen worden begrepen. In België wordt de consument evenwel reeds in belangrijke mate beschermd door de principes van de wet van I4 juli I99I op de handelspraktijken en de voorlichting en de bescherming van de consument ('Wet handelspraktijken'), zelf een omzetting van een Europese richtlijn. ${ }^{213}$ Bedingen die teveel in het nadeel van de consumentafnemer zijn opgesteld - de zogenoemde zwarte lijst - , zijn dan nietig.

Het derde pakket voegt aan het bovenstaande nog toe dat regulatoren alleszins de contractuele vrijheid met betrekking tot onderbreekbare leveringscontracten en langetermijnovereenkomsten dienen te respecteren, voor zover deze contracten verenigbaar zijn met het Gemeenschapsrecht en aansluiten bij het beleid van de Gemeenschap. ${ }^{214}$ Betekent dit dat regulatoren rechtstreeks zouden kunnen ingrijpen in 'onderbreekbare leveringscontracten' en in 'langetermijnovereenkomsten' indien deze niet verenigbaar zijn met het Gemeenschapsrecht of indien zij niet conform zijn aan het beleid van de Gemeenschap? Dit werd niet uitdrukkelijk voorzien en is ook alleszins geen voor de hand liggende gevolgtrekking.

Indien de regulatoren vaststellen dat onderbreekbare leveringscontracten en langetermijnovereenkomsten niet verenigbaar zijn met het Gemeenschapsrecht en/of niet aansluiten bij het beleid van de Gemeenschap, zullen zij dit dienen te melden aan bv. de Europese Commissie en/of een procedure voor het Hof van Justitie dienen op te starten.

213. Artikelen 3I-34 van de wet van I4 juli I99I betreffende de handelspraktijken en de voorlichting en bescherming van de consument, B.S. 29 augustus I99I, err. B.S. Io oktober I99I. Deze wet is een omzetting van richtlijn 2005/29/EG van het Europees Parlement en de Raad van II mei 2005 betreffende oneerlijke handelspraktijken van ondernemingen jegens consumenten op de interne markt en tot wijziging van Richtlijn 84/450/EEG van de Raad, Richtlijnen 97/7/EG, 98/27/EG en 2002/65/EG van het Europees Parlement en de Raad en van Verordening (EG) nr. 2006/2004 van het Europees Parlement en de Raad.

2I4. Artikel 37, lid I (l) van Elektriciteitsrichtlijn 2009/72/EG en artikel 4I, lid I (l) van Aardgasrichtlijn 2009/73/EG. In dat verband kan ook worden verwezen naar het arrest van het Hof van Justitie van 7 juni 2005, C-I7/03, VEMW e.a./Dienst uitvoering en Toezicht Energie e.a. Voor enkele commentaren hierop, zie P. Baeten, 'De toekomst van de historische contracten na het arrest van het Europees Hof van 7 juni 2005 - postjudiciële vragen bij prejudiciële antwoorden' in T. Vanden Borre (ed.), De vrijmaking van de elektriciteits- en gasmarkt: defederale wetgeving in een stroomversnelling, reeks Energie\&Recht, Antwerpen, Intersentia, 2006, I89-2Io; en G. Van Calster en L. Deridder, 'De toekomst van de historische contracten na het arrest van het Europees Hof van 7 juni 2005' in T. Vanden Borre (ed.), De vrijmaking van de elektriciteits- en gasmarkt: de federale wetgeving in een stroomversnelling, reeks Energie\&Recht, Antwerpen, Intersentia, 2006, I69-I88. 
In het voorgaande hebben we een beperkt overzicht gegeven van de nieuwe bepalingen van het derde pakket waarbij wordt voorzien in aantal bijkomende bevoegdheden voor de regulatoren en een aantal bepalingen die de onafhankelijkheid van de regulatoren zullen trachten te versterken. In de loop van de komende jaren en uiterlijk tegen 3 maart 2or dienen deze bepalingen te worden geïmplementeerd in de Belgische wetgeving op federaal en gewestelijk niveau. Het strekt tot aanbeveling dat men de bepalingen van de Elektriciteitsrichtlijn 2009/72/EG en Gasrichtlijn 2009/73/EG bij hun omzetting zeer grondig bestudeert opdat men voorziet in een correcte en volledige omzetting (in tegenstelling tot het verleden) van beide richtlijnen en opdat de Europese Commissie de Belgische kust hiervoor niet in gebreke zal moeten stellen.

\section{Beroepen tegen de beslissingen van een regulator}

\section{I Algemeen}

Uit het voorgaande kan worden afgeleid dat de regulatoren in de Belgische elektriciteit- en gasmarkt over een reeks bevoegdheden beschikken die kunnen leiden tot bindende beslissingen waarmee de marktpartijen niet noodzakelijk akkoord zijn en bijgevolg hun geschil willen laten beslechten in een jurisdictionele procedure.

Een jurisdictioneel beroep wordt in de rechtsleer omschreven als een beroep dat wordt ingesteld bij een rechtscollege van de rechterlijke orde, bij een administratief rechtscollege of bij een buitengerechtelijk rechtscollege of zelfs een orgaan van actief bestuur dat rechtsprekende bevoegdheid uitoefent. Bovendien is zulk beroep gebaseerd op een rechtsregel, die vervolgens zal leiden tot een beslissing met een specifieke draagwijdte dat een einde maakt aan een geschil en bekleed is met het gezag van gewijsde. ${ }^{215}$ Tot voor kort werden in de Elektriciteitswet, noch in de Gaswet specifieke bepalingen opgenomen die zulk jurisdictioneel beroep inrichten waardoor marktpartijen die hun geschil met de CREG willen laten beslechten zich dienen te wenden tot een administratief rechtscollege, met name de Raad van State, en/of een rechtscollege van de rechterlijke orde.

Marktpartijen die niet akkoord gaan met een beslissing van één van de gewestelijke regulatoren, VREG, CWAPE of BRUGEL, zullen bij gebreke aan specifieke bepalingen in de desbetreffende decreten of ordonnanties zich moeten wenden tot een administratief rechtscollege en/of een rechtscollege van de rechterlijke orde. Hierna zal vooreerst worden stilgestaan met de rechtsbescherming door de Raad van State.

215. A. Mast, J. Dujardin, M. Van Damme en J. Vande Lanotte, Overzicht van het Belgisch administratief recht, $\mathrm{I}^{\mathrm{e}} \mathrm{dr} ., 2002$, Mechelen, Kluwer, p. 755. 


\subsection{Rechtsbescherming door de Raad van State}

Ter aanvulling van de subjectieve rechtsbescherming bij de gewone rechter werd de Raad van State opgericht. De opzet van dit rechtscollege was het verhelpen van het gebrek aan rechtsbescherming tegenover de overheid. Het wettigheidstoezicht dat werd uitgevoerd door de hoven en rechtbanken werd in belangrijke mate beperkt tot louter een toetsing aan vormgebreken en bevoegheidsproblemen. De hoven en rechtbanken waren zeker niet meteen bereid om in te grijpen als de overheid haar discretionaire bevoegdheid mogelijks abusief had aangewend. Om dit gebrek aan rechtsbescherming tegen de overheid op te vangen werd aan de Raad van State een algemene en onbepaalde bevoegdheid toegekend tot het vernietigen van bestuurshandelingen. ${ }^{216}$

De Raad van State bestaat uit een afdeling wetgeving, die aan de (materiële) wetgever adviezen verleent, ${ }^{217}$ en een afdeling bestuursrechtspraak die naast verschillende adviesbevoegdheden ook over een administratief rechtscollege beschikt dat over diverse geschillen uitspraak doet. ${ }^{218}$ Hieronder zullen we ons beperken tot een bespreking van de regels van het annulatieberoep van administratieve beslissingen, genomen door de regulatoren, door het administratief rechtscollege van de Raad van State. ${ }^{219}$

De bevoegdheid voor de uitoefening van dit annulatieberoep put de Raad van State uit het artikel I4, SI van de R.v.St.-wet, die haar bevoegd maakt om 'uitspraak te doen, bij wijze van arresten, over de beroepen tot nietigverklaring wegens overtreding van hetzij substantiële, hetzij op straffe van nietigheid voorgeschreven vormen, overschrijding of afwending van macht, ingesteld tegen de akten en reglementen van de onderscheiden administratieve overheden, [...]'. Om te bepalen of al dan niet tegen de rechtshandelingen van de regulatoren een annulatieberoep kan worden ingesteld bij de Raad van State dient in eerste instantie op grond van artikel I4, SI van de R.v.St.-wet te worden aangetoond dat deze regulatoren kunnen worden gekwalificeerd als administratieve overheden.

Het begrip 'administratieve overheid' is niet wettelijk gedefinieerd. Bijgevolg hebben de rechtsleer en de rechtspraak zowel organieke als functionele criteria aangewend om uit te maken of bepaalde rechtshandelingen al dan niet uitgaan van administratieve overheden. Op basis hiervan kunnen administratieve overheden worden gedefinieerd als 'de niet onder de rechterlijke of andere wetgevende macht ressorterende instellingen of lichamen die door een openbare macht zijn opgericht

2I6. S. Lust, Rechtsherstel door de Raad van State, in Administratieve Rechtsbibliotheek, Brugge, die Keure, 2000, p. 93.

217. Artikelen 2 t.e.m. 6bis van de gecoördineerde wetten van I2 januari I973 op de Raad van State, B.S. 2 I maart 1973 (hierna R.v.St.-wet).

2I8. Artikelen 7 t.e.m. I8 van de R.v.St.-wet.

2I9. S. Lust, 'Naar de gewone rechter of naar de Raad van State?', P. Van Orshoven (ed.), Gerechtelijk privaatrecht, Themis, Brugge, die Keure, 2000, pp. 87-88. 
om in een openbare dienst of in een dienst van openbaar nut te voorzien, waarvan die macht de organisatie regelt en de werkwijze of de statuten bepaalt en kan wijzigen, en waaraan de bevoegdheid is opgedragen om beslissingen vast te stellen die uitwerking hebben t.a.v. derden'. ${ }^{220}$

Als organiek criterium kan uit deze omschrijving worden afgeleid dat een administratieve overheid deel uitmaakt van de uitvoerende macht of onder de uitvoerende macht ressorteert. Zo kan bv. de oprichting of de erkenning door de uitvoerende macht, alsook de organisatie en het toezicht door de openbare macht bepalend zijn om uit te maken of een orgaan al dan niet een administratieve overheid is in de zin van artikel I4, SI van de R.v.St.-wet. De functionele criteria die uit de hierboven vermelde omschrijving kunnen worden afgeleid hebben betrekking op de aard of de inhoud van de opdracht of de bevoegdheid van het betrokken orgaan. Indien een orgaan bijgevolg een opdracht van algemeen belang vervult of een openbare dienst verzekert, of over de bevoegdheid beschikt om eenzijdige en bindende gezagshandelingen te stellen, kunnen zulke functionele criteria erop wijzen dat het desbetreffende orgaan een administratieve overheid is. ${ }^{22 I}$

In haar arresten van 6 september 2002 in de zaken L.J. tegen de Katholieke Universiteit Leuven en M.G tegen het Instituut Zusters van de Onbevlekte Ontvangenis v.z.w. heeft het Hof van Cassatie zich uitgesproken over de vraag welke organen administratieve overheden zijn. ${ }^{222}$ Uit deze arresten kan worden afgeleid dat een instelling als een administratieve overheid dient te worden beschouwd als het een rechtspersoon betreft die is opgericht of wordt erkend door een publieke rechtspersoon waarvan de werking door de overheid wordt bepaald en gecontroleerd, en die beslissingen kan nemen die derden binden, meer bepaald door de eigen verplichtingen tegenover anderen eenzijdig te bepalen of door verplichtingen van die anderen eenzijdig vast te stellen. Bovendien dienen de handelingen van dergelijke instellingen een deel van het openbaar gezag uit te oefenen. ${ }^{223}$

Rechtsleer en rechtspraak voorzien in een aantal voorwaarden opdat een administratieve rechtshandeling kan worden aangevochten middels een annulatieberoep bij de Raad van State. Zo moet een administratieve rechtshandeling eenzijdig en uitvoerbaar zijn. De door de wet voorziene georganiseerde administratieve beroepen dienen te zijn uitgeput. ${ }^{224}$ Daarnaast dient de verzoeker op basis van het artikel I9,

220. A. Mast, J. Dujardin, M. Van Damme en J. Vande Lanotte, l.c., p. 952.

22I. S. Lust, 'Naar de gewone rechter of naar de Raad van State?', l.c., pp. 89-9o en zie ook S. LUST, 'Wat is een administratieve overheid? De wet motivering bestuurshandelingen', NjW 2004, afl. 84, pp. 1046-I050.

222. Cass. AR C.02.0I77.N, 6 september 2002 (L.J./Katholieke Universiteit Leuven), Arr.Cass. 2002, afl. 9, I747 en Cass. AR C.or.0382.N, 6 september 2002 (M.G./Instituut Zusters van de Onbevlekte Ontvangenis V.Z.W.), Arr.Cass. 2002, afl. 9, I742.

223. Noot J. De Staercke, 'Wat is een administratieve overheid? De Cassatiearresten van 6 september 2003', T.B.P. 2003/I, p. 62-66.

224. Voor een verdere analyse zie A. Mast, J. Dujardin, M. Van Damme en J. Vande Lanotte, l.c., pp. 947-950 en 960 en M. Boes, Administratief recht, $9^{\mathrm{e}}$ dr., 2005, Leuven, ACCO, pp. 344-346. 
SI van de R.v.St.-wet uiteraard ook blijk te geven van een benadeling of een belang bij de vernietiging. Tenslotte moet het beroep tot nietigverklaring tegen een beslissing tijdig worden ingediend, dit is binnen zestig dagen nadat zij werd bekendgemaakt of werd betekend. ${ }^{225}$

Hierbij kan erop worden gewezen dat naast het annulatieberoep de wetgever bij de wet van I9 juli I99I ${ }^{226}$ de Raad van State tevens bevoegd heeft gemaakt om als administratieve kortgedingrechter, alle nodige maatregelen, met uitzondering van de maatregelen die betrekking hebben op burgerlijke rechten, te bevelen om de belangen van de partijen of van de personen die een belang hebben bij de oplossing van de zaak, veilig te stellen. Op basis hiervan werd de Raad van State voortaan bevoegd om bij wijze van onverwijlde, maar voorlopige voorziening en bij voorraad alle nuttige maatregelen te treffen om, in afwachting van een beslissing ten gronde, alvast de eventuele kwalijke gevolgen van een onrechtmatig lijkende bestuurshandeling te neutraliseren (de zgn. schorsingsbevoegdheid van de Raad van State op grond van artikel 17 van de R.v.St.-wet). ${ }^{27}$ Daartoe is vereist dat de middelen ernstig zijn, en dat er sprake is van een moeilijk te herstellen en ernstig nadeel. Indien er sprake is van spoedeisendheid, kan de Raad van State zelfs worden gevat bij uiterst dringende noodzakelijkheid. ${ }^{228}$

Indien we de hierboven vermelde organieke en functionele criteria toepassen op de regulatoren kan volgens de auteurs hieruit worden geconcludeerd dat deze telkens kunnen worden gekwalificeerd als administratieve overheden in de zin van artikel I4, SI van de R.v.St-wet. Zij zijn immers opgericht door de wetgever/decreetgever/ ordonnantiegever als publiekrechtelijke autonome organismen. Door toezicht te houden en controle uit te oefenen op de elektriciteits- en de gasmarkten oefenen zij een bepaalde vorm van openbare dienst uit. Zij werken autonoom van de overige marktpartijen, maar staan onder toezicht van de uitvoerende en/of de wetgevende macht, aan wie zij verantwoording zijn verschuldigd. Tevens kunnen zij eenzijdige, en soms zelfs reglementaire, bindende beslissingen nemen.

225. Artikel 4, derde lid van het Besluit van de Regent van 23 augustus I 948 tot regeling van de rechtspleging voor de afdeling administratie van de Raad van State, B.S. 23 en 24 augustus 1948.

226. Wet van I9 juli I9gI tot wijziging van de wetten op de Raad van State, gecoördineerd op I 2 januari I973, houdende uitvoering van het administratief kortgeding, B.S. II mei 1999.

227. Voor een verdere analyse van het administratief kortgeding zie A. Mast, J. Dujardin, M. Van Damme en J. Vande Lanotte, l.c., pp. 989-Ioro, en R. Stevens, Raad Van State. Afdeling bestuursrechtspraak - het procesverloop, reeks administratieve rechtsbibliotheek, Brugge, die Keure, 2007, 5I5-6I5.

228. Zie artikel I7, §I van de R.v.St.-wet. 
Het is dan ook tegen deze beslissingen dat de marktpartijen een annulatieberoep of een vordering tot schorsing kunnen indienen bij de Raad van State. ${ }^{229}$

De bevoegdheid van de Raad van State wordt als residuair beschouwd aangezien de Raad van State niet bevoegd zal zijn indien andere jurisdictionele beroepsmogelijkheden openstaan met hetzelfde onderwerp. Behoudens in voorkomend geval als cassatierechter is de Raad van State niet bevoegd indien de wetgever heeft voorzien in een uitdrukkelijk georganiseerd beroep bij een administratieve rechter. Wanneer de rechtzoekende bovendien terecht kan bij de hoven en rechtbanken en daar eenzelfde resultaat kan bekomen, is de Raad van State evenmin bevoegd. Door de oprichting van de Raad van State heeft de wetgever immers geen afbreuk willen doen aan de bevoegdheden van de hoven en rechtbanken, maar enkel willen voorzien in een aanvulling van de jurisdictionele rechtsbescherming van de hoven en rechtbanken. In dit kader heeft de wetgever een aantal bestuursgeschillen expliciet toevertrouwd aan de hoven en rechtbanken waaronder de bevoegdheid van de vrederechter inzake onteigeningen, de bevoegdheid van de arbeidsrechtbank inzake het gros van het sociale zekerheidscontentieux, de bevoegdheid van het Hof van Cassatie voor handelingen van de onderscheiden ordes van de advocaten, inclusief de reglementen van de nationale orde van de advocaten, etc.

Deze rechtsbescherming door de Raad van State is reeds verregaand, maar verre van volmaakt en vertoont een aantal tekortkomingen. De rechtszoekende verkrijgt door de annulatie minstens gedeeltelijk herstel in natura aangezien de oorzaak van de rechtskrenking uit de rechtsordening wordt verwijderd. Maar dit rechtsherstel is niet steeds volledig omdat aan de gevolgen van de geannuleerde rechtshandeling in beginsel niet wordt geraakt. Bovendien is de verzoeker soms verstoken gebleven van bepaalde voordelen of bekomt hij uiteindelijk datgene waar hij recht op had, maar met soms heel veel vertraging. De retroactieve werking van de vernietiging kan de feitelijke werkelijkheid niet veranderen. Tegelijkertijd zal in die situaties waar schade is ontstaan het vernietigingsarrest geen uitvoerbare titel verlenen aan de schadelijder om de overheid te dwingen hem daartoe te vergoeden. Bijgevolg zullen bijkomende procedures noodzakelijk zijn om het bijkomende rechtsherstel te bekomen. ${ }^{230}$

229. Zie de studie van de CREG (F) 050608-CDC-4I6 over het wetsontwerp tot organisatie van de mogelijkheden tot beroep tegen de beslissingen genomen door de commissie, voorzien door de wet van 12 april $1_{9} 65$ betreffende het vervoer van gasachtige producten en andere door middel van leidingen en de wet van 29 april 1999 betreffende de organisatie van de elektriciteitsmarkt, gemaakt met toepassing van artikel 23, \$2, tweede lid, $2^{\circ}$ van de wet van 29 april 1999 betreffende de organisatie van de elektriciteitsmarkt en artikel $\mathrm{I}_{5} / \mathrm{I} 4$, $\$ 2$, tweede lid, $2^{\circ}$ van de wet van $\mathrm{I} 2$ april I965 betreffende het vervoer van gasachtige producten en andere door middel van leidingen van 8 juni 2005 , pp. 3 en 4 .

230. S. Lust, 'Naar de gewone rechter of naar de Raad van State?', l.c., pp. 98-Io2. 
Daarnaast heeft de Raad van State in de praktijk te kampen met een aanzienlijke gerechtelijke achterstand en is de procedure voor de Raad van State niet steeds de meest aangewezen procedure in sommige materies. Hiervan getuige de diverse beslissingen van de regulatoren waartegen sommige marktpartijen een vordering tot nietigverklaring hebben ingediend bij de Raad van State en waarbij een uitspraak van de Raad van State lang op zich laat wachten.

\subsection{Rechtsbescherming door de hoven en rechtbanken}

De Grondwet maakt de hoven en rechtbanken van rechtswege bevoegd om kennis te nemen van geschillen waarin een administratie is betrokken. De rechtsmacht in bestuursgeschillen van deze hoven en rechtbanken is immers gebaseerd op de artikelen I44 en I45 van de Grondwet die bepalen dat: 'geschillen over burgerlijke rechten behoren bij uitsluiting tot de bevoegdheid van de rechtbanken' en 'geschillen over politieke rechten behoren tot de bevoegdheid van de rechtbanken, behoudens de bij wet gestelde uitzonderingen.'

Volgens deze grondwetsbepalingen zijn de hoven en rechtbanken met andere woorden de rechters van het gemene recht wat de geschillen over subjectieve rechten betreft, waarbij hun bevoegdheid in geschillen over burgerlijke subjectieve rechten tevens exclusief is. Daarentegen kan de wetgever bij wijze van uitzondering de beslechting over politieke subjectieve rechten toekennen aan andere rechtscolleges dan de hoven en rechtbanken. Bij stilzwijgen van de wetgever behoren de politieke subjectieve rechten tot de bevoegdheidssfeer van de hoven en rechtbanken. ${ }^{23}$

De bevoegdheid van de hoven en rechtbanken inzake bestuursgeschillen wordt traditioneel gebaseerd op het artikel I59 van de Grondwet en de artikelen I382 en I383 van het Burgerlijk Wetboek. Op grond van artikel 159 van de Grondwet passen de hoven en rechtbanken de algemene, provinciale en plaatselijke besluiten en verordeningen alleen toe in zoverre ze overeenstemmen met de wetten. Dit grondwetsartikel geeft met andere woorden het recht aan de hoven en rechtbanken om onrechtmatige bestuurshandelingen buiten toepassing te laten. Artikel I59 van de Grondwet is van openbare orde, waardoor de rechter in beginsel verplicht is, zelfs ambtshalve, om de wettigheid van een administratieve rechtshandeling te onderzoeken. Bovendien geldt deze verplichting niet alleen voor de hoven en rechtbanken maar voor alle met rechtspraak belaste organen en dus ook voor andere rechtscolleges.

Deze wettigheidstoetsing slaat zowel op de externe (waarbij wordt onderzocht of de overheid bevoegd is en of de bestuurshandeling in overeenstemming is met de geldende vormschriften) als de interne legaliteit (waarbij wordt onderzocht of er al dan niet machtsafwending en/of machtsoverschrijding is) van bestuurshandelingen. Daarenboven moet het begrip 'wetten' in artikel I59 van de Grondwet ruim

23I. A. Mast, J. Dujardin, M. Van Damme en J. Vande Lanotte, l.c., pp. 798-802 en S. Lust, l.c., Rechtsherstel door de Raad van State, p. 77. 
worden opgevat waardoor de bestuurshandelingen moeten worden getoetst op hun overeenstemming met alle wetten in materiële zin, alsook met het gewoonterecht en de algemene rechtsbeginselen.

Noteer dat aan artikel 159 van de Grondwet wel een belangrijke beperking is verbonden aangezien dit artikel geen autonoom beroep inricht voor de rechtzoekende maar een zijdelingse vorm van rechtsbescherming blijft die enkel kan worden opgeworpen in het raam van een geschil. Eens de hoven en rechtbanken op een geldige wijze zijn gevat kunnen zij het onrechtmatige overheidsoptreden beteugelen aan de hand van een uitgebreid gamma van maatregelen. Hun sanctioneringsmogelijkheid is daarbij niet louter beperkt tot het buiten toepassing plaatsen van een onwettige bestuurshandeling. Zij kunnen de overheid tevens verbieden om de bestuurshandeling nog langer verder uit te voeren (negatieve injunctie). Tegelijkertijd kunnen de hoven en rechtbanken actief maatregelen nemen om een einde te stellen aan de onwettigheid en de desbetreffende overheid daarbij zelfs gebieden bepaalde handelingen nog te stellen (positieve injunctie). Hierbij moet de rechter in de uitoefening van zijn bevoegdheden wel steeds het algemeen rechtsbeginsel van de scheiding der machten respecteren waardoor hij zijn beoordeling niet in de plaats kan stellen van de administratieve overheid indien deze over een discretionaire bevoegdheid beschikt. ${ }^{232}$

Naast de exceptie van illegaliteit op grond van het artikel I59 van de Grondwet kunnen de hoven en rechtbanken op basis van de artikelen 1382 en 1383 van het Burgerlijk Wetboek de overheid veroordelen tot het vergoeden van de schade die zij heeft aangericht door haar wederrechtelijk handelen. De jurisprudentie in dit kader heeft ook een ganse evolutie meegemaakt die heeft geleid tot een geleidelijk uitdeinende aansprakelijkheid van de overheid waarbij de hoven en rechtbanken steeds vaker openbare rechtspersonen zijn gaan veroordelen tot het betalen van een schadevergoeding indien inbreuken werden gepleegd op de subjectieve rechten van de bestuurde. ${ }^{233}$

Uit het voorgaande kan worden afgeleid dat de marktpartijen tegen de beslissingen van de regulatoren ook beroep kunnen doen op de hoven en rechtbanken die enerzijds toepassing kunnen maken van de exceptie van illegaliteit en anderzijds de overheidsaansprakelijkheid.

232. S. Lust, 'Naar de gewone rechter of naar de Raad van State?', l.c., pp. 78-8I en S. Lust, Rechtsherstel door de Raad van State, l.c., pp. II3-I29.

233. Voor een grondigere analyse van de evolutie van de rechtspraak hieromtrent zie S. Lust, 'Naar de gewone rechter of naar de Raad van State?', l.c., pp. 8I-85 en A. Mast, J. Dujardin, M. Van Damme en J. Vande Lanotte, l.c., pp. 83I-853. 


\subsection{Naar de Raad van State of naar de hoven of rechtbanken tegen de beslissingen van een regulator?}

Tegen de beslissingen van de regulatoren staat dus zowel een vordering voor de hoven en rechtbanken, al dan niet in kort geding, als een annulatieberoep of een vordering tot schorsing (al dan niet bij uiterst dringende noodzakelijkheid) bij de Raad van State open. Waarbij de bevoegdheid van de Raad van State of deze van de hoven en rechtbanken telkens afhankelijk zal zijn van de wijze waarop men de vordering zal inkleden. Indien door een onwettige beslissing van één van de regulatoren de subjectieve rechten van een marktpartij worden aangetast, of ingeval van kort geding in voorkomend geval dreigen te worden aangetast, en men een vordering tot voorlopige maatregelen of herstel door een injunctie of een pecunaire schadevergoeding zal inleiden dan zijn de hoven en rechtbanken bevoegd. Indien men daarentegen een vordering tot schorsing en/of annulatie zou inleiden tegen een beslissing van één van de regulatoren omdat diens beslissing een objectief recht schendt, dan is de Raad van State bevoegd. ${ }^{234}$

Bij welke rechter een marktpartij het best gediend zal zijn is steeds afhankelijk van de beslissing die de desbetreffende regulator heeft getroffen en de soort van herstelmaatregel die de rechtszoekende beoogt teneinde een zo volledig rechtsherstel te bekomen. Uiteraard verzet niets er zich tegen om zowel de hoven en rechtbanken als de Raad van State te adiëren in kort geding en/of ten gronde. Welke strategie men best kan volgen tegen een beslissing van één van de regulatoren kan men niet algemeen bepalen. Alles zal afhankelijk zijn van de omstandigheden van het geval zoals de aard van de bestreden beslissing van de desbetreffende regulator, het tijdsverloop sinds de bestreden beslissing van de desbetreffende regulator, de aard van de onwettigheid, de aard van het rechtsherstel dat een marktpartij wenst te bekomen, enzovoort.

\subsection{Beroepsprocedures tegen bepaalde beslissingen van de regulatoren}

Naast de jurisdictionele beroepen van het gemene recht, een vordering voor de hoven en rechtbanken, al dan niet in kort geding, of een annulatieberoep dan wel een vordering tot schorsing bij de Raad van State, heeft de federale wetgever bij de wetten van 20 en 27 juli 2005 voorzien in specifieke beroepsmogelijkheden tegen bepaalde beslissingen van de CREG. ${ }^{235}$

Deze wetten bepalen tegen welke beslissingen van de CREG voortaan, hetzij bij het hof van Beroep te Brussel, hetzij bij de Raad voor de Mededinging een beroep kan worden ingesteld, alsook de voorwaarden en de procedure waaraan zulk beroep dient

234. S. Lust, 'Naar de gewone rechter of naar de Raad van State?', l.c., p. Io2.

235. Wet 20 juli 2005 houdende diverse bepalingen, B.S. 29 juli 2005 en wet 27 juli 2005 tot organisatie van de mogelijkheden tot beroep tegen de beslissingen genomen door de Commissie voor de Regulering van de Elektriciteit en het Gas, B.S. 29 juli 2005. 
te voldoen om ontvankelijk te zijn. Daarnaast voorziet de wet van 20 juli 2005 dat de tenuitvoerlegging van bepaalde beslissingen van de CREG door de ministerraad kan worden geschorst wanneer deze de wet schenden, het algemeen belang schaden of in strijd zijn met de krachtlijnen van het energiebeleid van het land. ${ }^{236}$

Volgens de memorie van toelichting van de wetten van 20 en 27 juli 2005 wordt de inrichting van de beroepsprocedure verantwoord doordat de Gaswet en de Elektriciteitswet geen bijzondere beroepsmechanismen voorzien tegen de beslissingen van de CREG en bijgevolg onderworpen zijn aan het gemene recht. Dit is volgens de memorie van toelichting niet meer aangepast aan de huidige praktijk die onder meer blijkt in andere sectoren van het recht. Tevens verwijst de memorie van toelichting bij wijze van verantwoording naar het federale regeerakkoord van I2 juli 2003, ${ }^{237}$ de Europese richtlijnen en naar analoge bepalingen in de financiële sector. ${ }^{23^{8}} \mathrm{De}$ desbetreffende bepaling van het federale regeerakkoord stelt dat:

'Het beleid inzake de vrijmaking van de elektriciteit- en gasmarkt zal tevens slagkrachtiger worden door een duidelijke lijn te trekken tussen de beleidsvoorbereidende taken van de administratie en de taken van de CREG als regulator van de marktwerking. Dit betekent dat de federale administratie over de nodige informatie moeten kunnen beschikken teneinde haar beleidsvoorbereidende taak te kunnen uitvoeren. Anderzijds worden de taken van de CREG als onafhankelijke marktregulator versterkt. Tevens zal de mogelijkheid worden ingevoerd om beslissingen van de CREG aan te vechten bij het Brusselse Hof van Beroep via een versnelde procedure.'239

Of de wetgever door de invoering van de beroepsprocedure gevolg heeft gegeven aan al de elementen uit deze passage van het federale regeerakkoord, is betwistbaar.

Een andere verantwoording voor het opzetten van dergelijke beroepsprocedure op federaal niveau kan volgens diezelfde memorie van toelichting worden gevonden in zesde lid van respectievelijk het artikel 23 van de Tweede Elektriciteitsrichtlijn en het artikel 25 van de Tweede Aardgasrichtlijn, dat telkens voorziet dat benadeelde partijen over de mogelijkheid dienen te beschikken om een klacht in te dienen binnen een termijn van ten hoogste twee maanden tegen de beslissingen van de

236. B. Delvaux, 'De specifieke beroepsprocedure tegen de beslissingen van de CREG', in T. Vanden Borre (ed.), De vrijmaking van de elektriciteits- en gasmarkt: de federale wetgeving in een stroomversnelling?, Antwerpen, Intersentia, 2006, pp. 2II-249.

237. Noteer dat de memorie van toelichting verwijst naar de verklaring van de federale regering van I4 juli 2003 maar in deze verklaring werden geen bepalingen opgenomen in verband met de beroepsprocedure. Bijgevolg was het waarschijnlijk de bedoeling van de wetgever om te verwijzen naar het federale regeerakkoord van 12 juli 2003. Bovendien werd het citaat van het federale regeerakkoord waarnaar de wetgever heeft verwezen ook niet letterlijk overgenomen.

238. Parl. St., Memorie van Toelichting, Kamer, GZ/2004-2005, I845/I, pp. 53-55 en Parl. St., Memorie van Toelichting, Kamer, GZ/2004-2005, I895/I, pp. 3-6.

239. Federale Regeerakkoord van 12 juli 2003, Een creatief en solidair België, p. 3 I. 
regelgevende instantie, alsook tegen de relevante instantie die de tariefbeslissingen van de regelgevende instantie kan goedkeuren of verwerpen. ${ }^{240}$

Zoals werd verduidelijkt in het vorige hoofdstuk van deze bijdrage kunnen de marktpartijen binnen een termijn van zestig dagen, nadat de bestreden akte van de CREG werd bekendgemaakt of betekend, een annulatieberoep inleiden bij de Raad van State. Hieruit kan worden afgeleid dat de huidige wetgeving op dit punt reeds in overeenstemming is met de bepalingen van de Elektriciteits- en Gasrichtlijn. Het is dan ook niet meteen duidelijk waarom de wetgever in de memorie van toelichting heeft verwezen naar beide richtlijnen om zijn wetgevend initiatief te verantwoorden. ${ }^{24 I}$

Noteer dat een duidelijke afbakening van deze beroepsmogelijkheden in het bijzonder voor de CREG als administratieve overheid belangrijk is. De CREG is immers op grond van artikel 2, $4^{\circ}$ van de wet van II april 1994 betreffende de openbaarheid van bestuur verplicht om op iedere beslissing of administratieve handeling met individuele strekking de eventuele beroepsmogelijkheden, de instanties bij wie het beroep moet worden ingesteld en de geldende vormen en termijnen te vermelden. Bij gebreke van deze informatie zou de verjaringstermijn naar gelang de situatie geen aanvang nemen voor het indienen van een beroep tegen de desbetreffende beslissing van de CREG. ${ }^{242}$

De gewestelijke overheden hebben, met uitzondering tegen de beslissingen tot het opleggen van een administratieve boete, tot op heden dergelijke beroepsprocedures tegen de (welbepaalde) beslissingen van hun respectievelijke regulatoren nog niet voorzien. Zoals hierboven reeds werd gesteld, kan elke belanghebbende een beroep instellen tegen de beslissingen van de VREG en de CWaPE tot het opleggen van een administratieve geldboete voor de Rechtbank van Eerste Aanleg. ${ }^{243}$ In artikel 569, $33^{\circ}$ Ger.W. werd deze bijkomende bevoegdheid voor de Rechtbank van Eerste Aanleg ingeschreven. Er werd geen bijzondere territoriale bevoegdheid voorzien, zodat in principe de Rechtbank van Eerste Aanleg 'van de woonplaats van de verweerder' - dit is steeds de regulator - bevoegd is. ${ }^{244}$ Tegen een beslissing tot het opleggen van een administratieve geldboete door BRUGEL, staat een georganiseerd administratief

240. Parl. St., Memorie van Toelichting, Kamer, GZ/2004-2005, I845/I, p. 54 en Parl. St., Memorie van Toelichting, Kamer, GZ/2004-2005, I895/I, p. 5.

24I. Zie de studie van de CREG (F) 050608-CDC-4I6, l.c., pp. 8-9.

242. Zie eveneens artikel I9, tweede lid van de R.v.St.-wet die gelijkaardige bepalingen bevat, alsook de rechtspraak van de Raad van State hieromtrent die stelt dat de verjaringstermijn, zelfs indien de bepaling van artikel I9, tweede lid van de R.v.St.-wet niet werd nageleefd, wel een aanvang neemt wanneer de verzoekende partij kennis had van de beroepstermijn. Zie A. Mast, J. Dujardin, M. Van Damme en J. Vande Lanotte, l.c., p. 708 en F. Schram, Openbaarheid van bestuur, in Administratieve Rechtsbibliotheek, Brugge, Die Keure, 2003, pp. 175-177.

243. Artikel 37, \$4 van het Vlaamse Elektriciteitsdecreet; artikel 47 van het Vlaamse Aardgasdecreet; artikel 53 sexies van het Waalse Elektriciteitsdecreet en artikel 48 sexies van het Waalse Aardgasdecreet. Zie ook artikel I3.3.I, \$4 van het Vlaamse Energiedecreet.

244. Artikel 624, I ${ }^{\circ}$ Ger.W. 
beroep open bij de Regering van het Brussels Hoofdstedelijk Gewest. ${ }^{245}$ In alle gevallen werkt het beroep schorsend.

Noteer ten slotte nog dat het Waalse Elektriciteitsdecreet in een specifiek georganiseerd hoger beroep voorziet tegen de beslissingen van de geschillenkamer van de CWaPE bij het Hof van Beroep te Luik, zetelend zoals in kort geding.

Indien bij het eerste pakket van de staatshervorming, het tarievenbeleid en de prijzenmonitoring zou worden overgeheveld naar de gewesten is het misschien aangewezen om mits een aantal (grondige) wijzigingen te voorzien in gelijkaardige beroepsprocedures op gewestelijk niveau. Hierna zal vervolgens worden stilgestaan bij de schorsingsbevoegdheid van de ministerraad.

\subsection{Schorsing door de ministerraad in de Elektriciteits- en Gaswet}

De Ministerraad kan, op voorstel van de Minister van energie, bij gemotiveerd besluit, de tenuitvoerlegging schorsen van de beslissingen genomen door de CREG met toepassing van de artikelen I2 van de Elektriciteitswet en I5/5, \$2 van de Gaswet en hun uitvoeringsbesluiten. ${ }^{246}$ Deze bepalingen hebben betrekking op de tarieven van de netbeheerder, de beheerder van het aardgasvervoersnet, de beheerder van de opslaginstallatie voor aardgas en de beheerder van de LNG-installatie. De ministerraad kan overgaan tot dergelijke schorsing indien de CREG door haar beslissing de wet zou schenden, het algemeen belang zou schaden of wanneer de ministerraad oordeelt dat de beslissing strijdig is met de krachtlijnen van het energiebeleid van het land, met inbegrip van de doelstellingen inzake de energiebevoorrading van het land. Vervolgens bepalen beide artikelen dat de CREG de Ministerraad onmiddellijk op de hoogte brengt na het aannemen van de hierboven vermelde beslissingen.

Het besluit tot schorsing wordt genomen binnen een termijn van dertig dagen vanaf de ontvangst van de beslissing van de CREG door de ministerraad. ${ }^{247}$ Indien de ministerraad overgaat tot een schorsing wordt dit besluit meteen bekend gemaakt aan de CREG en de belanghebbenden. De CREG dient vervolgens, binnen een termijn van vijftien dagen te rekenen vanaf de schorsing van de beslissing, de geschorste beslissing te wijzigen en in overeenstemming te brengen met het in de ministerraad getroffen besluit.

Beroep tegen de beslissing van de ministerraad is ontvankelijk indien terzelfder tijd een beroep wordt ingesteld tegen de gewijzigde beslissing van de CREG. ${ }^{248}$ Volgens de memorie van toelichting wordt dit verantwoord door het feit dat de CREG

245. Artikel 32 van de Elektriciteitsordonnantie en artikel 24 van de Aardgasordonnantie.

246. Zie artikel 29sexies, SI, eerste lid van de Elektriciteitswet en artikel I5/23, SI, eerste lid van de Gaswet.

247. Zie artikel 29sexies, §I, derde lid van de Elektriciteitswet en artikel I5/23, §I, derde lid van de Gaswet.

248. Zie artikel 29sexies, §2 van de Elektriciteitswet en artikel I5/23, §2 van de Gaswet. 
binnen de vijftien dagen vanaf de schorsing door de ministerraad haar geschorste beslissing dient te wijzigen en in overeenstemming te brengen met datgene wat de ministerraad heeft beslist. Bovendien is het volgens de memorie van toelichting niet opportuun om een beroep in te stellen tegen het besluit van de ministerraad en tegen de geschorste beslissing van de CREG omwille van het korte tijdbestek, alsook een aparte behandeling van beide beroepen. ${ }^{249}$

Uit rechtspraak van de Raad van State blijkt dat tegen de beslissingen van de ministerraad een annulatieberoep of een vordering tot schorsing kan worden ingeleid bij de Raad van State. ${ }^{25}$ Bijgevolg kan tegen het besluit van de ministerraad tot schorsing van de beslissing van de CREG een annulatieberoep of een vordering tot schorsing worden ingeleid bij de Raad van State mits wordt voldaan aan de diverse voorwaarden van zulk een procedure. Daarnaast staat uiteraard naargelang de inkleding van de vordering en het beoogde rechtsherstel nog een beroep open bij de hoven en rechtbanken op grond van het gemene recht. Wat de gewijzigde, gelet op de tussenkomst van de ministerraad, beslissing van de CREG betreft staat een beroep open bij het Brusselse hof van Beroep, naar gelang de situatie, op grond van het artikel 2gbis, §I, $6^{\circ}$ van de Elektriciteitswet of het artikel I5/20, §I, $6^{\circ}$ van de Gaswet. Noteer evenwel dat het gaat om een gewijzigde beslissing van de CREG die wordt opgelegd door de ministerraad. Bijgevolg zou men mogelijks kunnen argumenteren dat zulke gewijzigde beslissing, geen beslissing meer is van de CREG, wat uiteraard zijn impact heeft op de beroepsprocedure. ${ }^{25}$

In dit kader kan erop worden gewezen dat de voorziene schorsingsbevoegdheid in hoofde van de ministerraad, waarbij de ministerraad zal opleggen welke beslissing de CREG dient te nemen, volgens de auteurs in strijd is met de Tweede Elektriciteitsen Gasrichtlijnen. Op grond van de artikelen 23, lid 3 van de Tweede Elektriciteitsrichtlijn en 25, lid 3 van de Tweede Gasrichtlijn: 'kunnen de lidstaten voorschrijven dat de regelgevende instanties (lees de CREG) de tarieven of ten minste de in dat lid bedoelde methoden alsook de in lid 3 bedoelde wijzigingen aan de relevante instantie (lees de regering, minister, ...) in de lidstaat voorleggen met het oog op een formeel besluit. Deze tarieven, methoden of wijzigingen worden samen met het besluit inzake de formele aanneming bekendgemaakt. De relevante instantie is in een dergelijk geval bevoegd een door de regelgevende instantie voorgelegd ontwerpbesluit goed te keuren of te verwerpen. [...]' (eigen cursivering)

249. Parl. St., Memorie van Toelichting, Kamer, GZ/2004-2005, I845/I, p. 62.

250. R.v.St., De gemeente Sint-Pieters-Woluwe e.a., nr. I26.669 van ig december 1993 en R.v.St., vzw Vlaams Nationaal Jeugdverbond, nr. 77.6I8 van I4 december 1998.

25I. De afdeling wetgeving van de Raad van state stelde in dit kader terecht dat bij een beroep, tegen enerzijds de geschorste beslissing van de Ministerraad die zou worden ingesteld bij de Raad van State en anderzijds een beroep tegen de gewijzigde beslissing van de CREG bij het Brusselse hof van Beroep, kan leiden tot tegenstrijdige rechterlijke beslissingen. Om dit te vermijden suggereerde de Raad van State om zulke beroepen tegen de beslissingen van de Ministerraad onder het jurisdictioneel toezicht te plaatsen van het hof van Beroep te Brussel maar de wetgever heeft hieraan geen gevolg gegeven. 
Hieruit kan worden afgeleid dat de regering of de minister de CREG niet kan opleggen wat ze precies moet vermelden in haar beslissing. Deze visie wordt bevestigd in de Note of DG TREN on Directives 2003/54/ EC and 2003/55/EC on the internal market in electricity and natural gas - the role of the regulatory authorities. Deze note stelt dat: 'The Directive does allow for the possibility that a Regulator's decision can be reviewed by the relevant Ministry' en tegelijktertijd wordt in de voetnoot vermeld dat: 'more specifically the Ministry should not be permitted to either accept or reject the decision; it may not amend the decision of the regulatory authority.' ${ }^{252}$

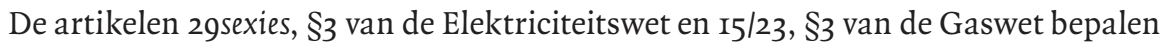
dat de Koning de nadere regels voor de schorsingsprocedure door de ministerraad zal bepalen. Tot op heden werd hieraan geen gevolg gegeven, niettemin werd het koninklijk besluit van 27 mei 2008 tot opschorting van de uitvoering van de beslissing (B)o80515-CDC-656G/07 van I5 mei 2008 van de Commissie voor de Regulering van de Elektriciteit en het Gas afgekondigd. Deze beslissing van de CREG voorzag in voorlopige doorvoertarieven voor de toegang en het gebruik van het vervoersnetwerk van Fluxys. Het is zeer de vraag of dergelijke schorsing door de ministerraad een jurisdictionele toetsing zou doorstaan.

\subsection{Beroep bij het Hof van Beroep te Brussel}

Naast de schorsingsbevoegdheid voorzien de artikelen 2gbis van de Elektriciteitswet en I5/20 van de Gaswet ook in de mogelijkheid voor elke persoon met een belang om een beroep in te stellen tegen welbepaalde beslissingen van de CREG bij het hof van Beroep van Brussel, dat zal beslissen in kort geding. De keuze voor het hof van Beroep te Brussel is volgens de memorie van toelichting een tendens in België, waarbij de federale regering zich aansluit, en die erop gericht is om het Hof van Beroep de bevoegdheid te geven in geschillen die een snelle beslissing, een uniciteit in de rechtspraak en een specialisatie van de magistraten vereisen. Als voorbeelden van deze tendens verwijst de memorie van toelichting naar de beroepsprocedure tegen sommige beslissingen van de Commissie voor het bank-, financie- en assurantiewezen (afgekort CBFA) en het Belgisch Instituut voor postdiensten en telecommunicatie (afgekort BIPT).

Beide artikelen van de Elektriciteits- en Gaswet voorzien in een ganse lijst van beslissingen waartegen beroep kan worden ingesteld bij het hof van Beroep van Brussel. Deze lijst verwijst telkens naar de diverse taken die door de CREG zijn toegewezen op grond van de artikelen 23, §2, tweede lid van de Elektriciteitswet en I5/I4, \$2, tweede lid van de Gaswet. ${ }^{253}$ Bijgevolg kan op grond van artikel 29bis van de Elektriciteitswet een beroep worden ingesteld tegen de beslissingen van de CREG met betrekking tot:

252. Note on the role of the regulatory authorities, p. I.

253. Zie de studie van de CREG (F) 0506o8-CDC-4I6, l.c., pp. 34-35. 
$\mathrm{I}^{\circ}$ de controle op de naleving door de netbeheerder van de bepalingen van artikel 9 en de uitvoeringsbesluiten ervan;

Deze bepaling heeft betrekking op de verplichtingen die de netbeheerder moet naleven in het kader van zijn oprichting; de activiteiten die hij mag ondernemen; de lidmaatschapsrechten die hij mag bezitten; de samenstelling en de taken van de raad van bestuur, het auditcomité, het vergoedingscomité, het corporate covernance comité; de bevoegdheden van het directiecomité; etc.

$2^{\circ}$ de controle op de toepassing van het technisch reglement bedoeld in artikel II en de uitvoeringsbesluiten ervan met uitzondering van de beslissingen bedoeld in artikel 29ter;

Hierbij beoogt de wetgever de beslissingen die door de CREG worden genomen in het kader van het technisch reglement, die werden vastgesteld bij het koninklijk besluit van I9 december 2002 houdende een technisch reglement voor het beheer van het transmissienet van elektriciteit en de toegang ertoe. ${ }^{254}$ De verwijzing naar artikel 29ter van de Elektriciteitswet, die bij de wet van I juli $2006^{255}$ werd ingevoerd, betreft de bepalingen die voorzien in de beroepsprocedure die kan worden ingesteld bij de Raad voor de Mededinging. Door deze wijziging kan men enkel een beroep instellen in verband met de toepassing van het technisch reglement bij het Hof van Beroep voor zover dit niet onder de bevoegdheid ressorteert van de Raad van de Mededinging.

$3^{\circ}$ de controle op de uitvoering door de netbeheerder van het ontwikkelingsplan bedoeld in artikel $\mathrm{I} 3$ en de uitvoeringsbesluiten ervan;

$4^{\circ}$ de controle op en de evaluatie van de uitvoering van de openbare dienstverplichtingen bedoeld in artikel 2I, eerste lid, $\mathrm{I}^{\circ}$ en de uitvoeringsbesluiten ervan en, desgevallend, betreffende de toepassing van de afwijkingen die zijn toegestaan krachtens artikel 2I, eerste lid, $2^{\circ}$ en de uitvoeringsbesluiten ervan;

Dit heeft betrekking op de openbare dienstverplichtingen die kunnen worden opgelegd aan de producenten, tussenpersonen, leveranciers en de netbeheerder. Deze bepaling werd verder uitgevoerd door het koninklijk besluit van II oktober 2002 met betrekking tot de openbare dienstverplichtingen in de elektriciteitsmarkt. ${ }^{25} 6$

254. B.S. 28 december 2002.

255. Wet van I juli 2006 tot wijziging van de wet van I2 april I 965 betreffende het vervoer van gasachtige producten en andere door middel van leidingen en de wet van 29 april 1999 betreffende de organisatie van de elektriciteitsmarkt - Erratum, B.S. 2 februari 2002.

256. B.S. 29 oktober 2002. 
$5^{\circ}$ de goedkeuring van de berekeningsmethode en de controle van de berekeningen van de kosten en verliezen bedoeld in artikel $2 \mathrm{I}$, eerste lid, $3^{\circ}$, a) en de uitvoeringsbesluiten ervan;

De oprichting van het fonds om de volledige of een deel van de reële nettokost van de opgelegde openbare dienstverplichtingen te financieren werd opgenomen in het koninklijk besluit van 8 juli 2003 tot wijziging van het koninklijk besluit van 24 maart 2003 tot bepaling van de nadere regels betreffende de federale bijdrage tot financiering van sommige openbare dienstverplichtingen en van de kosten verbonden aan de regulering en controle op de elektriciteitsmarkt en van het koninklijk besluit van II oktober 2002 met betrekking tot de openbare dienstverplichtingen in de elektriciteitsmarkt. ${ }^{257}$

$6^{\circ}$ de goedkeuring van de tarieven voor de aansluiting op het transmissienet en voor het gebruik ervan bedoeld in artikel I2 tot I2novies van de wet en van de uitvoeringsbesluiten ervan;

$7^{\circ}$ het toezicht op het feit dat de tarifering voor de levering van elektriciteit gericht is op het algemeen belang en zich in het globale energiebeleid integreert en in voorkomend geval betreffende het toezicht op het maximumprijzen die toepasselijk zijn op de eindafnemers en distributeurs die afnemers bevoorraden die geen in aanmerking komende afnemers zijn; ${ }^{25}$

$8^{\circ}$ controle van de rekeningen van de ondernemingen uit de elektriciteitssector bedoeld in artikel 22 en de uitvoeringsbesluiten ervan;

$9^{\circ}$ de administratieve boeten.

Naast deze bepalingen in de Elektriciteitswet werd op grond van artikel 15/20 van de Gaswet voorzien in een beroep bij het hof van beroep van Brussel tegen de beslissingen van de CREG met betrekking tot:

$\mathrm{I}^{\circ}$ de goedkeurig van de voorwaarden voor toegang tot het aardgasvervoersnet en het toezicht op de toepassing ervan met uitzondering van de beslissingen bedoeld in artikel I5/2obis, ${ }^{\circ}$;

$2^{\circ}$ het toezicht op en de evaluatie van de openbare dienstverplichtingen bedoeld in artikel I5/II en de uitvoeringsbesluiten ervan;

257. B.S. 6 augustus 2003 , noteer dat de oprichting van dit fonds oorspronkelijk was opgenomen in de artikelen 6 tot en met 9 van het koninklijk besluit van II oktober 2002.

258. Noteer dat de CREG deze bevoegdheid heeft verkregen naar aanleiding van de afschaffing van het Controlecomité voor de Elektriciteit en Gas, zie hierover T. Vanden Borre en B. Delvaux, 'Recente ontwikkelingen in het federale energiebeleid en -recht', in K. Deketelaere (ed.), Jaarboek Energierecht 2003, Antwerpen - Groningen - Oxford, Intersentia, 2003, pp. 65-66. 
Deze bepaling heeft betrekking op diverse uitvoeringsbesluiten,waaronder het koninklijk besluit van 23 oktober 2002 betreffende de openbare dienstverplichtingen in de aardgasmarkt ${ }^{259}$, het koninklijk besluit van 24 maart 2003 tot vaststelling van een federale bijdrage bestemd voor de financiering van bepaalde openbare dienstverplichtingen en van de kosten verbonden aan de regulering van en controle op de aardgasmarkt, ${ }^{260}$ enzovoort.

$3^{\circ}$ het toezicht op en de evaluatie van de toepassing van artikel $15 / 7$ en de uitvoeringsbesluiten ervan;

$4^{\circ}$ het toezicht op en de evaluatie van de toepassing van de bepalingen van artikel $23 \mathrm{bis}$ van de Elektriciteitswet en de uitvoeringsbesluiten ervan; ${ }^{261}$

$5^{\circ}$ de controle van de boekhouding van de ondernemingen uit de aardgassector bedoeld in de artikelen $15 / 5$ tot $15 / 5$ decies en de uitvoeringbesluiten ervan;

$6^{\circ}$ de goedkeuring van de tarieven bedoeld in artikel $15 / 5$ tot 15/5decies en de uitvoeringsbesluiten ervan;

$7^{\circ}$ de administratieve boeten.

Noteer dat sinds de afkondiging van deze bepalingen de federale wetgever door wetswijzigingen een aantal tekortkomingen aan de hierboven vermelde bepalingen heeft rechtgezet. ${ }^{262}$

Uit het voorgaande blijkt dat de wetgever niet heeft voorzien in een beroep tegen alle beslissingen die de CREG kan nemen op basis van de Elektriciteits- en Gaswet. Bijgevolg staat, met uitzondering van de beslissingen die worden onderworpen aan het toezicht van de Raad voor de Mededinging, voor sommige beslissingen van de CREG nog steeds zowel een vordering voor de hoven en rechtbanken, al dan niet in kort geding, als een annulatieberoep of een vordering tot schorsing bij de Raad van State open, waarbij de bevoegdheid van de Raad van State of deze van de hoven en rechtbanken afhankelijk zal zijn van de wijze waarop men de vordering zal inkleden en welk rechtsherstel men nastreeft.

259. B.S. 6 november 2002 .

260. B.S. 28 maart 2003.

26I. Deze bepaling heeft ook betrekking op de bevoegdheden die de CREG heeft gekregen naar aanleiding van de afschaffing van het Controlecomité voor Elektriciteit en Gas, zie voetnoot n ${ }^{\circ} 55$.

262. Voor een overzicht van een aantal van deze tekortkomingen zie B. Delvaux, 'De specifieke beroepsprocedure tegen de beslissingen van de CREG', l.c., pp. 2II-249. Het betreft ondermeer het erratum van de wet van I juli 2006 tot wijziging van de wet van I 2 april ig 65 betreffende het vervoer van gasachtige producten en andere door middel van leidingen en de wet van 29 april 1999 betreffende de organisatie van de elektriciteitsmarkt, B.S. 2 februari 2007 en de wet van I juli 2007 houdende diverse bepalingen, B.S. 28 juli 2006. 
Zoals reeds vermeld is de bevoegdheid van de Raad van State residuair waardoor zij niet bevoegd zal zijn indien andere jurisdictionele beroepsmogelijkheden openstaan met hetzelfde onderwerp. Bijgevolg kan uit de analyse van de artikelen 2gbis van de Elektriciteitswet en 15/20 van de Gaswet en de memorie van toelichting bij deze bepalingen, alsook de beroepsprocedure bij het hof van Beroep van Brussel in de financiële en telecomsector waarnaar de memorie van toelichting bij de artikelen 2gbis van de Elektriciteitswet en 15/20 van de Gaswet meermaals heeft naar verwezen, volgens ons worden geconcludeerd dat de wetgever voor die welbepaalde beslissingen van de CREG ervoor heeft gekozen om alleen het Hof van Beroep van Brussel bevoegd te maken om uitspraak te doen in de beroepen tegen deze beslissingen van de CREG. De Raad van State is dan niet (meer) bevoegd om uitspraak te doen over een beroep tegen deze beslissingen van de CREG. Deze visie werd ook bevestigd in recente rechtspraak van de Raad van State waarbij zij oordeelde dat:

'de [...] annulatiebevoegdheid van de Raad van State [...] algemeen [is], in die zin dat zij zich uitstrekt over alle administratieve rechtshandelingen van de Belgische administratieve overheden. De Raad van State is echter niet bevoegd om een administratieve rechtshandeling van een orgaan van het actief bestuur te vernietigen wanneer zijn bevoegdheid wordt uitgesloten op grond van een specifieke wetsbepaling die een beroep mogelijk maakt bij hoven en de rechtbanken dat tot een gelijkwaardig resultaat kan leiden.'

Op basis van het voorgaande oordeelde de Raad van State dat de bevoegdheid van het Hof van Beroep te Brussel de bevoegdheid van de Raad van State uitsluit. ${ }^{263}$

Paragraaf 2 van de artikelen 29bis van de Elektriciteitswet en 15/20 van de Gaswet bepaalt bovendien dat het Brusselse hof van Beroep over de grond van de zaak uitspraak doet met volle rechtsmacht. Hieromtrent stelt de memorie van toelichting dat het begrip 'volle rechtsmacht' naar het recht verwijst om kennis te nemen van het volledige geschil, van alle feitelijke en rechtelijke aspecten ervan en een uitspraak ten gronde te doen. ${ }^{264}$ Tegelijkertijd wordt in de memorie van toelichting bij het artikel 29quater, \$7 van de Elektriciteitswet, dit is de oorspronkelijke vermelding van de volle rechtsmacht in hoofde van het Brusselse Hof van Beroep dat tengevolge van het advies van de afdeling wetgeving van de Raad van State werd geschrapt, verdere toelichting gegeven omtrent de interpretatie die de wetgever geeft aan de volle rechtsmacht van het Hof van Beroep te Brussel. Het Hof zou bijgevolg over de bevoegdheid beschikken om zijn beoordeling volledig in de plaats te stellen van deze van de CREG, zowel feitelijk als rechtelijk. Tevens verwijst de memorie van toelichting naar de principes die van toepassing zijn op de procedure met betrekking tot bepaalde beslissingen van de CBFA, waarbij het hof de beslissing waartegen

\footnotetext{
263. R.v.St. nr. I95.I72, I5 juli 2009. Noteer dat de Raad van State in de arresten met als nummer I95.I73 tot en met I95.278 op I5 juli 2009 tot dezelfde conclusie is gekomen.

264. Parl. St., Memorie van Toelichting, Kamer, GZ/2004-2005, I845/I, p. 59 en Parl. St., Memorie van Toelichting, Kamer, GZ/2004-2005, I895/I, p. 9.
} 
beroep werd aangetekend niet alleen kan annuleren maar ook hervormen en een beslissing kan nemen die de aangevochten beslissing vervangt. ${ }^{265}$

Uit sommige rechtsleer kan worden afgeleid dat de rechtsmacht van de rechter op de grens ligt tussen de gebonden en de discretionaire bevoegdheid van de overheid. Bijgevolg zou de scheiding der machten de substitutie en reformatie door de rechter niet beletten voorzover het telkens een gebonden bevoegdheid betreft. In zulke situatie zou de rechter door zijn handeling in de plaats te stellen van de overheidshandeling niet treden in de vrije beoordeling van de overheid aangezien deze vrije beoordeling per definitie niet bestaat ingeval van een gebonden bevoegdheid. Noteer evenwel dat de uitvoeringsimmuniteit van de overheid de substitutie en reformatie door de rechter zou beletten voorzover de gedwongen tenuitvoerlegging de continuïteit van het openbaar bestuur in het gedrang kan brengen. ${ }^{266}$

Niettemin, is in de praktijk gebleken dat indien de wetgever aan de rechterlijke macht uitdrukkelijk de volle rechtsmacht toekent, de rechterlijke macht niet meteen hiervan toepassing maakt maar eerder terugdeinst om de volheid van zijn bevoegdheid zonder meer uit te oefenen en bijgevolg zich volledig in de plaats te stellen van de overheid. Dit kan worden afgeleid uit het arrest van I8 juni 2004 waarbij het Brusselse Hof van Beroep zich terughoudend opstelde in de uitoefening van zijn bevoegdheid in volle rechtsmacht. Het hof stelde in dit arrest dat het bevoegd was 'met volle rechtsmacht' maar wees er ook op dat:

'Encore faut-il que la cour puisse substituer sa décision à l'acte attaqué sur la base des
éléments versés au dossier sans heurter le principe de la séparation des pouvoirs en
privant l'IBPT, autorité réglementaire nationale, de son pouvoir d'appréciation, ni
méconnaître les dispositions des nouvelles directives qui édictent des obligations
d'informations et de coopération équivoques à la charge des autorités réglementaires
[...].

Or, [...] la cour ne peut sous peine de priver l'IBPT de sa liberté d'appréciation et se substituer ainsi à lui ; déterminer elle-même de quelle manière celui-ci doit exercer ses pouvoirs, ni choisir à la place de l'autorité réglementaire nationale la solution qui semble la plus appropriée dans les limites fixées par la loi.' ${ }^{267}$

Hieruit kan worden afgeleid dat het Brusselse Hof van Beroep, in tegenstelling tot de wettelijke bepalingen die haar een volle rechtsmacht toekent, op grond van het beginsel van de scheiding der machten terugdeinst om zich volledig in de plaats te

265. Parl. St., Memorie van Toelichting, Kamer, GZ/2004-2005, I845/I, p. 6I.

266. S. Lust, 'Naar de gewone rechter of naar de Raad van State?, l.c., pp. 85-86.

267. Zie de studie van de CREG (F) 050608-CDC-4I6, l.c., p. 65, die verwijst naar de website van het BIPT, www.ibpt.be, waar het desbetreffende arrest werd gepubliceerd, het betreft arrest Nr. $2004 / 4308$. 
stellen van een administratieve overheid. ${ }^{268}$ Deze visie werd bevestigd in één van de eerste arresten die het Brusselse Hof van Beroep te Brussel heeft geveld op basis van haar nieuwe bevoegdheden waarin het hof stelde dat:

'Deze toewijzing van de volle rechtsmacht houdt nochtans niet in dat het hof een beslissing in de plaats moet stellen van deze die het desgevallend onwettig heeft bevonden en dat het navolgend de bevoegdheid uitoefent die wettelijk toekomt aan de overheid die de vernietigde beslissing heeft getroffen.

De wetgever heeft het hof dus niet opgedragen om te beslissen als regulator in beroep.

In geval de vordering tegen de CREG wordt ingewilligd, heeft deze als regulator desgevallend opnieuw te beslissen in overeenstemming met hetgeen het hof heeft

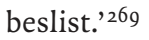

Uit het arrest WVEM/CREG van het Brusselse Hof van Beroep van Io november 2008 kan worden afgeleid dat het hof de hierboven vermelde visie met betrekking tot de volle rechtsmacht enigszins wijzigde door de door haar adequaat bevonden motieven in de plaats te stellen van de motieven van de CREG. Het hof stelde in dit arrest dat:

'De gegrondheid van de grief inzake bevoegdheidsoverschrijding doordat afschrijvingsvoeten werden opgelegd zonder nadere motivering heeft in het voorliggende geval niet voor gevolg dat de bestreden beslissing dient te worden vernietigd.

Uit de behandeling van de grief is immers ook gebleken dat de beslissing van de CREG om de betwiste afschrijvingsvoeten toe te passen inhoudelijk adequaat was.

De CREG dient derhalve niet opnieuw te beslissen over de aanvraag tot goedkeuring van een tariefvoorstel met budget voor het exploitatiejaar 2007. Het hof stelt de adequaat bevonden motieven in de plaats ten aanzien van de bestreden beslissing en bevestigt de vastgestelde tarieven. Het tarief wordt ten gronde verworpen' (eigen cursivering) ${ }^{270}$

268. Zie de studie van de CREG (F) 050608-CDC-4I6, l.c., pp. 64-65; Voor een grondige analyse van de mogelijkheid van een jurisdictioneel toezicht van de rechterlijke macht tegen de beslissingen van administratieve overheden zie de studie van de CREG (F) 050608-CDC-4I6, l.c., pp. 52-66.

269. Brussel 27 februari 2007, WVEM/CREG, nr. 2007/I596, paragraaf 26.

270. Brussel ro november, WVEM/CREG, nr. 2008/8407, paragraaf 44 . 
Naast dit arrest heeft het Hof van Beroep diverse arresten ${ }^{271}$ geveld waarbij onder meer de kostenbeoordelingsbevoegdheid van de CREG werd beperkt. ${ }^{272}$ Het is zeer de vraag of dergelijke rechterlijke toetsing waarbij het Hof van Beroep van Brussel zich in de plaats gaat stellen van de CREG in overeenstemming is met datgene wat de Europese wetgever beoogde. Verder onderzoek of een prejudiciële vraagstelling aan het Hof van Justitie zal moeten uitmaken in welke mate een nationale rechter de tarifaire bevoegdheid van de regulerende instanties kan beoordelen.

Vervolgens bepalen de artikelen 29quater van de Elektriciteitswet en I5/2I van de Gaswet de ganse procedure en de diverse voorwaarden die dienen te worden nageleefd in de beroepsprocedure bij het Hof van Beroep van Brussel. Beide artikelen stellen dat het indienen van het beroep bij het Hof van Beroep op basis van de artikelen 2 bis van de Elektriciteitswet en 15/20 van de Gaswet geen schorsende werking heeft ten aanzien van de beslissingen van de CREG, tenzij het is ingesteld tegen een beslissing van de CREG tot het opleggen van een administratieve geldboete. Bovendien voorzien beide artikelen dat het Hof van Beroep de schorsing van de tenuitvoerlegging van de beslissing van de CREG kan bevelen indien de aanvrager ernstige middelen inroept die de vernietiging of herziening van de beslissing mogelijk kunnen rechtvaardigen en als de onmiddellijke tenuitvoerlegging van de beslissing hem een ernstig en moeilijk te herstellen nadeel dreigt te berokkenen.

De paragrafen 2 tot en met 6 van de artikelen 29quater van de Elektriciteitswet en I5/2I van de Gaswet voorzien de diverse procedurevoorschriften die dienen te worden nageleefd in de beroepsprocedure, waaronder de diverse elementen van het verzoekschrift, het aantal verzoekschriften dat moet worden ingediend, de termijn voor de indiening van het verzoekschrift, termijnen voor de betekening en de doorzending van het administratief dossier door de CREG, etc. Ten slotte stelt paragraaf 6, tweede lid van de artikelen 29quater van de Elektriciteitswet en I5/2I van de Gaswet dat het Hof van Beroep van Brussel uitspraak doet binnen een termijn van zestig dagen na de neerlegging van het verzoekschrift.

\subsection{Beroep bij de Raad voor de Mededinging}

Op grond van de artikelen 29ter van de Elektriciteitswet kan door elke persoon die een belang aantoont een beroep worden ingesteld bij de Raad voor de Mededinging, tegen de beslissingen genomen door de CREG in toepassing van het artikel 23, \$2, tweede lid, $9^{\circ}$ van de Elektriciteitswet met betrekking tot de controle op de toepassing van het technisch reglement bedoeld in artikel II van de Elektriciteitswet en

27I. Brussel 5 maart 2007, WVEM/CREG, nr. 2007/I786, Brussel I2 november 2007, DNB BA/CREG, nr. 2007/8II3 en Brussel I8 december 2007, ALG/CREG, nr. 2007/9385.

272. Zie de ongepubliceerde tekstenbundel van de Parlementaire hoorzitting over de dading gesloten tussen de CREG en de gemengde netbeheerders van Io februari 2009 en in het bijzonder de daarin opgenomen nota van 28 november 2008 van T. Maes, 'Wankele bevoegdheid van de CREG inzake de tarieven voor de distributie van elektriciteit en aardgas'. 
de uitvoeringsbesluiten, voorzover de beslissing de goedkeuring, de aanvraag tot herziening of de weigering tot goedkeuring betreft van:

$\mathrm{I}^{\circ}$ de beslissingen van de netbeheerder betreffende de toegang tot het transmissienet, bedoeld in artikel I5 van de Elektriciteitswet, behalve in geval van contractuele rechten en verbintenissen;

$2^{\circ}$ de allocatiemethoden of methoden voor de toewijzing van de beschikbare capaciteit op de interconnectoren voor de elektriciteitsuitwisselingen met de buitenlandse transmissienetten.

Vooreerst kan uit het voorgaande worden afgeleid dat de Raad voor de Mededinging enkel bevoegd is voor de beslissingen die worden genomen in het kader van het technisch reglement en bijgevolg in uitvoering van het KB van I9 december 2002 houdende een technisch reglement voor het beheer van het transmissienet van elektriciteit en de toegang ertoe (hierna KB van I9 december 2002). Vervolgens wordt de bevoegdheid van de Raad voor de Mededinging verder gespecificeerd aangezien het de beslissingen van de netbeheerder betreft met betrekking tot de toegang tot het transmissienet in het kader van artikel I5 van de Elektriciteitswet, met uitzondering van de contractuele rechten en verbintenissen.

Op grond van dit artikel I5, §I, eerste lid van de Elektriciteitswet hebben de in aanmerking komende afnemers een recht van toegang tot het transmissienet tegen de tarieven vastgesteld overeenkomstig artikel I2 van de Elektriciteitswet. Daarnaast stelt het tweede lid van artikel I5, SI van de Elektriciteitswet dat de netbeheerder deze toegang alleen kan weigeren indien hij niet over de nodige capaciteit beschikt of wanneer de aanvrager niet voldoet aan de technische voorschriften van het technische reglement. Paragraaf 2 van het artikel I5 van de Elektriciteitswet voorziet in een uitbreiding voor enerzijds producenten en anderzijds tussenpersonen van datgene dat werd bepaald in het artikel I5, SI van de Elektriciteitswet. Daarnaast stelt paragraaf 3 van het artikel I5 van de Elektriciteitswet dat voor welbepaalde contracten over de commerciële voorwaarden voor de toegang wordt onderhandeld tussen de netbeheerder en de betrokken partij. ${ }^{273}$ Noteer dat artikel I5, \$3 van de Elektriciteitswet werd opgeheven door het artikel I3 van de Elektriciteitswet van I juni 2005.

Volledigheidshalve moet nog worden gewezen op de vermelding 'behalve in geval van contractuele rechten en verbintenissen'. Volgens de auteurs heeft dit louter te maken met het feit dat de Raad voor de Mededinging een administratief rechtscollege is en bijgevolg geen uitspraak kan doen over geschillen inzake burgerlijke rechten die uitsluitend tot de bevoegdheid behoren van de hoven en rechtbanken op grond van het artikel I44 van de Grondwet. Noteer dat in het artikel 29 van de Elektriciteitswet met betrekking tot de geschillenkamer dezelfde vermelding werd opgenomen.

273. Zie artikel 15, S 2 en 3 van de Elektriciteitswet. 
Met betrekking tot artikel $29 t e r, I^{\circ}$ van de Elektriciteitwet kan worden vastgesteld dat diverse bepalingen van het technische reglement toepassing maken van het artikel I5 waarbij de CREG beslissingen van de netbeheerder kan goedkeuren, weigeren goed te keuren of vragen te herzien. Daarnaast bepaalt artikel $29 t e r, 2^{\circ}$ van de Elektriciteitswet dat een beroep mogelijk is bij de Raad voor de Mededinging tegen beslissingen van de CREG die betrekking hebben de allocatiemethoden of methoden voor de toewijzing van de beschikbare capaciteit op de interconnectoren voor de elektriciteitsuitwisselingen met de buitenlandse transmissienetten. Hierbij beoogde de wetgever de beslissingen die de CREG neemt in het kader van artikel I83 van het KB van I9 december 2002, dat luidt als volgt:

'SI. De netbeheerder waakt over de uitvoering van één of meerdere methodes voor de toekenning van de beschikbare capaciteit aan de toegangsverantwoordelijken van energie-uitwisselingen met de buitenlandse netten.

\$2. Deze methodes zijn transparant en niet-discriminerend. Zij worden aan de commissie ter goedkeuring ter kennis gebracht en gepubliceerd overeenkomstig artikel 26 van dit besluit [...]'

Tevens kan door elke persoon die een belang aantoont, op grond van het artikel I5/2obis van de Gaswet, een beroep worden ingesteld bij de Raad voor de Mededinging tegen de beslissingen van de CREG tot goedkeuring, inzake de aanvraag tot herziening of weigering van:

$\mathrm{I}^{\circ}$ de beslissingen van de netbeheerder betreffende de toegang tot het vervoersnet, bedoeld in artikel 15/5 van de Gaswet, behalve in geval van contractuele rechten en verbintenissen;

$2^{\circ}$ de allocatiemethoden of methoden voor de hoeveelheid aardgas beschikbaar op de interconnectoren met de buitenlandse vervoersnetten.

Volgens de memorie van toelichting wordt de keuze voor een beroepsprocedure bij de Raad voor de Mededinging verantwoord door het feit dat: (a) een specifieke instantie uitspraak moet doen over een beroep tegen beslissingen van de CREG die nauw verbonden zijn met de bescherming van de economische mededinging; (b) de Raad voor Mededinging de instantie bij uitstek is om hierover een oordeel te vellen omwille van de aanwezige ervaring en specialistische kennis en (c) het zou getuigen van een gebrek aan efficiëntie om beslissingen waarbij in kortgeding omwille van het hoogdringende karakter een beslissing dient genomen te worden, te laten samenvallen met beslissingen die meer diepgaande en bijgevolg langere analyse 
vergen omdat ze mogelijks een marktverstorend of -belemmerend karakter in zich dragen. ${ }^{274}$

Daarnaast stellen de artikelen 29quinquies, SI van de Elektriciteitswet en I5/22, SI van de Gaswet dat het beroep bij de Raad voor de Mededinging onderworpen is aan de onderzoeksbepalingen en procedureregels met betrekking tot de restrictieve mededingingspraktijken zoals bepaald in de wetten van to juni 2006 tot bescherming van de economische mededinging en tot oprichting van een Raad voor de Mededinging. ${ }^{275}$ Paragraaf 2 van de artikelen 29quinquies van de Elektriciteitswet en 15/22 van de Gaswet bepalen vervolgens de termijn waarbinnen een beroep kan worden ingesteld bij de Raad voor de Mededinging. De Raad zal vervolgens binnen een termijn van vier maanden, zoals voorzien in de artikelen 16 en volgende van de Wet op de economische mededinging, uitspraak doen.

Volledigheidshalve dient erop te worden gewezen dat de artikelen 4 en 8 van de Wet 27 juli 2005 zowel in de Elektriciteits- als Gaswet alle verwijzingen schrappen die voorzien in een juridische band of mogelijke samenwerking tussen de CREG en de Raad voor de Mededinging. Dit valt eenvoudig te verklaren door het feit dat tegen welbepaalde beslissingen van de CREG men voortaan een beroep kan instellen bij de Raad voor de Mededinging. Tegelijkertijd voorziet artikel 4 van de Wet van 27 juli 2005 in de opheffing van het koninklijk besluit van 20 september 2002 betreffende de samenwerking tussen de CREG en de Dienst voor de Mededinging en het korps verslaggevers. ${ }^{276}$

Deze schrapping van een mogelijke samenwerking of juridische band tussen de CREG en de Raad voor de Mededinging werd bij de wet van 8 juni 2008 houdende diverse bepalingen, zoals hierboven werd vermeld, dan weer in zekere zin teniet gedaan aangezien de CREG in het kader van haar uitgebreide bevoegdheden met betrekking tot het vaststellen van anticompetitief gedrag, oneerlijke handelspraktijken en/of de monitoring van de prijzen een rapport van haar bevindingen dient over te maken aan de Raad voor de Mededinging. Een dergelijk rapport zou in de praktijk betrekking kunnen hebben op een beslissing van de CREG waarvoor men een beroep heeft ingediend of kan indienden bij de Raad voor de Mededinging. Opdat deze situatie zou kunnen worden vermeden strekt het tot de aanbeveling om de procedure bij de Raad voor de Mededinging tegen welbepaalde beslissingen van de CREG te schrappen in de Elektriciteits- en Gaswet.

In vergelijking met de beroepsprocedure bij het hof van Beroep van Brussel beschikt de Raad van de Mededinging niet over de volheid van rechtsmacht. Dit is perfect te verklaren door het feit dat de Raad voor de Mededinging een administratief

274. Parl. St., Memorie van Toelichting, Kamer, GZ/2004-2005, I845/I, p. 59 en Parl. St., Memorie van Toelichting, Kamer, GZ/2004-2005, I895/I, pp. 8-9.

275. B.S. 29 juni 2006.

276. Parl. St., Memorie van Toelichting, Kamer, GZ/2004-2005, I895/I, p. II. 
rechtscollege is dat deel uitmaakt van de uitvoerende macht en niet van de rechterlijke macht. Hierdoor zal de uitspraak van de Raad voor de Mededinging met betrekking tot de beslissing van de CREG waartegen beroep werd ingesteld, beperkt zijn tot een al dan niet nietigverklaring van de beslissing van de CREG. Bijgevolg zal de CREG in de situatie van een nietigverklaring een nieuwe beslissing kunnen treffen. ${ }^{277}$ Noteer dat tegen de beslissingen die de Raad voor de Mededinging heeft genomen als beroepsorgaan tegen de beslissingen van de CREG, het Hof van Cassatie bevoegd is om zich als cassatierechter in laatste instantie uit te spreken. ${ }^{278}$

\section{Rol van de regulator ter bescherming van de consument}

In een geliberaliseerde energiemarkt heeft de consument te maken met twee marktspelers: de leverancier en de distributienetbeheerder. ${ }^{279}$

\section{I Verhouding consument-leverancier}

De consument is vrij in zijn keuze van energieleverancier. Hij staat in een contractuele relatie met zijn leverancier. Excessen in de contractuele relatie, die het contractuele laken al te fel naar de leverancier toe zouden trekken, worden afgestraft door de Wet Handelspraktijken.

De regulator kan geen geschillen beslechten inzake burgerlijke rechten in de zin van artikel I44 van de Grondwet. Evenmin verlenen de technische reglementen - die trouwens de relatie tussen de afnemer en de distributienetbeheerder regelen - een regulator de mogelijkheid tot goed- of afkeuring van bepaalde contracten of contractuele bedingen.

Elektriciteitsrichtlijn 2009/72/EG en Aardgasrichtlijn 2009/73/EG verlenen de regulator de bevoegdheid om toezicht uit te oefenen op het voorkomen van restrictieve contractuele praktijken die " grote niet-huishoudelijke afnemers" kunnen weerhouden van of hen beperkingen kunnen opleggen met betrekking tot een keuze voor het gelijktijdig sluiten van overeenkomsten met meer dan een leverancier, en in voorkomend geval de nationale mededingingsautoriteiten van dergelijke praktijken in kennis te stellen'. Dit toezicht strekt zich niet uit tot contractuele praktijken met consumenten.

Zoals supra (hoofdstuk V, A) reeds gesteld, dient de decreetgever wel te bepalen welke rol hij aan de regulatoren zal toekennen met betrekking tot het 'helpen waarborgen'

277. Zie de studie van de CREG (F) 050608-CDC-4I6, l.c., p. 42.

278. Artikel 34 van de wet van Io juni 2006 tot oprichting van een Raad voor de mededinging, B.S. 29 juni 2006.

279. T. Vermeir, 'De consument in de geliberaliseerde energiemarkt' in Recht in Beweging - 16de VRGalumnidag 2009, Antwerpen, Maklu, 2009, 60. 
dat de in bijlage I bij Elektriciteitsrichtlijn 2009/72/EG en Aardgasrichtlijn 2009/73/ EG genoemde maatregelen ter bescherming van de consument doeltreffend zijn en gehandhaafd kunnen worden.

\subsection{Verhouding consument-distributienetbeheerder}

Vóór de liberalisering van de markten hadden rechtspraak en rechtsleer reeds uitgemaakt dat de rechtsverhouding tussen een afnemer-consument en het energiebedrijf (waaronder de dienst die instond voor de distributie van de elektriciteit en/of het gas) reglementair van aard was. ${ }^{280}$ Sinds de liberalisering heeft de hoge rechtspraak zich nog niet uitgesproken over de verhouding tussen de afnemer en de distributienetbeheerder.

Het Vlaams Technisch Reglement Distributie Elektriciteit en het Vlaams Technisch Reglement Distributie Gas bepalen dat 'voor elke nieuwe aansluiting op het hoogspanningsnet moet met de distributienetbeheerder een aansluitingscontract worden gesloten. Voor aansluitingen op het laagspanningsnet moet geen aansluitingscontract ondertekend worden. Voor die aansluitingen op het laagspanningsnet worden de voorwaarden opgenomen in het aansluitingsreglement van de distributienetbeheerder'. ${ }^{28 \mathrm{r}}$

Men zou kunnen stellen dat - in een geliberaliseerde markt, toch voor hoogspanning - de verhouding tussen de partijen niet gereglementeerd meer is. Nochtans betekent het feit dat een aansluitingscontract moet worden gesloten voor hoogspanning niet dat de rechtsverhouding afnemer-distributienetbeheerder contractueel zou zijn geworden.

Samen met Phang en Vermeir ${ }^{282}$ zijn de auteurs van mening dat deze verhouding, voor wat de elektriciteits- en de gasmarkten betreft, (nog steeds) reglementair van aard is. De distributienetbeheerders zijn immers intercommunales (al dan niet met de deelname van Electrabel), publiekrechtelijke overheden, die over een reglementaire bevoegdheid beschikken.

280. Cass. 27 november 2006, NjW 2008, afl. I74, 28-30, met noot I. Boone, 'Geen principiële uitsluiting buitencontractuele aansprakelijkheid bij rechtsverhouding van reglementaire aard'; RABG 2007, afl. I9, I257, met noot L. Phang, 'Over de rechtsverhouding tussen elektriciteitsmaatschappijen en hun afnemers en het samenloopverbod in deze verhouding', I264-I274. Zie ook A. Van Oevelen, 'De contractuele versus de reglementaire rechtsverhouding tussen openbare nutsbedrijven en hun gebruikers, en de rechterlijke toetsing van de in die rechtsverhouding gehanteerde exoneratieclausules', RW 2002-03, I578-I583, noot onder Cass. 4 december 2000; E. Dirix, 'Algemene contractvoorwaarden en monopolies', RW I986-87, 2724, noot onder Antwerpen, 20 januari 1987.

28I. Artikel 8.7.2 Vlaams Technisch Reglement Distributie Elektriciteit en artikel 5.6.2. Vlaams Technisch Reglement Distributie Aardgas.

282. T. Vermeir, 'De consument in de geliberaliseerde energiemarkt' in Recht in Beweging - 16de VRGalumnidag 2009, Antwerpen, Maklu, 2009, 6o e.v. 
De distributienetbeheerders kunnen algemeen bindende reglementen uitvaardigen. Deze reglementen zijn verbindend zodra zij, op de wijze door de wet bepaald, zijn bekend gemaakt.

De consument kan overigens zijn distributienetbeheerder niet kiezen, aangezien de distributie van elektriciteit en gas een wettelijk monopolie is. Bovendien moet de distributienetbeheerder zich van zijn kant onthouden van elke vorm van discriminatie tussen afnemers of categorieën van afnemers. De tarieven voor de aansluiting op en het gebruik van de distributienetten zijn trouwens gereguleerde tarieven. Zij moeten worden goedgekeurd door de CREG. Tenslotte wijzen wij er op dat de decreetgever verschillende openbaredienstverplichtingen heeft opgelegd aan de distributienetbeheerders, en dat de distributienetbeheerders verplicht zijn deze na te leven.

Dit alles leidt ertoe dat de rechtsverhouding tussen de consument en de distributienetbeheerder als reglementair kan worden beschouwd.

De rechtbanken dienen de reglementen toe te passen. Tegelijkertijd zijn zij verplicht om via het wettigheidstoezicht, zoals bepaald in artikel I59 van de Grondwet, te controleren of de reglementen de hiërarchisch hoger in de rang staande wetten niet schenden. Daarnaast dienen de reglementen de besluiten die hoger in de hiërarchie staan, te eerbiedigen. Hier kan worden gedacht aan de bestaande Technische Reglementen. Eventueel staat er hier een weg open om bepaalde onderdelen van de aansluitingsreglementen op hoger niveau te laten regelen, waardoor de (lagere) reglementen van de distributienetbeheerders zich hieraan dienen te conformeren.

Hiervoor (hoofdstuk IV, E, 2, ii) en iii)) werd reeds ingegaan op de bevoegdheden van de regulatoren ten aanzien van de distributienetbeheerders.

\section{Aansprakelijkheid van de regulator}

\section{I Aansprakelijkheid van een regulator}

De vier regulatoren zijn administratieve overheden. Er gelden in principe geen bijzondere gronden van (uitsluiting van) aansprakelijkheid.

Jegens een regulator kan allereerst diens aansprakelijkheid worden weerhouden door de onder toezicht staande marktpartij (producent, netbeheerder, ...). Zo kan een regulator bijvoorbeeld een vergunning voor een producent weigeren of intrekken, kan zij groenestroomcertificaten weigeren toe te kennen of kan zij door de netbeheerders voorgestelde tarieven weigeren toe te passen. Indien deze beslissingen onrechtmatig blijken - bijvoorbeeld doordat het besluit tot weigering of intrekking 
wordt vernietigd door de Raad van State -, dan zal de regulator aansprakelijk zijn voor de door hem veroorzaakte schade. Indien een besluit van een administratieve overheid wordt vernietigd, staat de fout van die overheid immers vast.

Daarnaast stelt zich de vraag naar de gevolgen van een gebrekkig toezicht ten aanzien van anderen dan de onder toezicht staande marktpartij. ${ }^{283}$

De bestaande rechtspraak inzake (buitencontractuele) overheidsaansprakelijkheid zal tevens van toepassing zijn op regulatoren. De rechtspraak ter zake maakt duidelijk dat het algemeen zorgvuldigheidscriterium moet geconcretiseerd worden naar de specifieke situatie van het normaal redelijk en zorgvuldig openbaar bestuur in dezelfde feitelijke omstandigheden, die de rechter, gegeven de scheiding der machten, niet toelaat de politieke wenselijkheid van het overheidsoptreden politiek te beoordelen. ${ }^{284}$ Voor een regulator moet een rechter dus nagaan of zij heeft gehandeld zoals een normaal zorgvuldig regulator, geplaatst in dezelfde feitelijke omstandigheden, zou hebben gehandeld.

Hierin schuilt een groot verschil met de aansprakelijkheid van de Belgische toezichthouder op de financiële markten, de CBFA. Naar Belgisch recht geldt, sedert de wet van 2 augustus 2002, een beperking van aansprakelijkheid van de CBFA in de uitoefening van al haar toezichtstaken, tot zware fout of bedrog. ${ }^{285}$

De aansprakelijkheid van de financiële toezichthouder in Nederland is, net zoals de aansprakelijkheid van de regulatoren in de energiemarkt, niet wettelijk beperkt. In principe zijn deze regulatoren dan ook aansprakelijk voor alle schade die zij veroorzaken wegens een fout, dat wil zeggen indien zij niet handelen zoals een normaal zorgvuldig regulator, geplaatst in dezelfde feitelijke omstandigheden, zou hebben gehandeld.

Onze Nederlandse collega's stellen voor om, gezien het feit dat in de financiële sector het risico van aansprakelijkheid van de toezichthouder tot een onbeheersbaar niveau kan stijgen (vb. een bank die omvalt), in dat geval een (hoog) maximum aan de aansprakelijkheid in te voeren. Aangezien in principe evenwel de lichtste fout

283. Bv. de schade geleden door klanten van een elektriciteitsbedrijf wiens leveringsvergunning ten onrechte werd ingetrokken door de regulator (voor zover de regulator hiertoe bevoegd is).

284. Zie H. Vandenberghe, 'Recente ontwikkelingen bij de foutaansprakelijkheid' in H. Cousy en $\mathrm{H}$. Vandenberghe, Aansprakelijkheids- en verzekeringsrecht, reeks Themis nr. 48, Brugge, die Keure, p. 76 e.v. Zie ook Cass. 25 oktober 2004, NJW 2004, afl. 9I, I3I6, met noot.

285. Artikel 68 van de Wet van 2 augustus 2002 betreffende het toezicht op de financiële sector en de financiële diensten, B.S. 4 september 2002. Deze beperking van aansprakelijkheid, die werd verantwoord door de specificiteit van het financiële toezicht, geeft overigens aanleiding tot een - vooralsnog beperkt - spillover-effect: bij de omzetting van de Europese Auditrichtlijn in Belgisch recht heeft de regelgever immers een gelijkaardige aansprakelijkheidsbeperking in de wet ingeschreven ten gunste van het Instituut van Bedrijfsrevisoren (zie artikel 22, \$5 Wet 22 juli I953). Zie ook M. Tison, 'Aansprakelijkheid van de financiële toezichthouder: conflictenrechtelijke vragen in een Europeesrechtelijke context', in Van Alle Markten - Liber Amicorum Eddy Wymeersch, Antwerpen, Intersentia, 2008, 857. 
volstaat om tot aansprakelijkheid te moeten besluiten, leidt dergelijke maximumaansprakelijkheid er niet toe dat in bepaalde gevallen de regulator, behoudens overmacht dan, niet aansprakelijk zal kunnen worden gesteld. Zij zal wegens een fout steeds aansprakelijk kunnen worden gehouden. Enkel zal de door haar te betalen schadevergoeding worden beperkt tot een wettelijk bepaalde cap. Dergelijke cap lijkt ons best te worden gekoppeld aan een index teneinde de marktprijzen te volgen.

Anderzijds zal een regulator waarschijnlijk niet zo snel aansprakelijk worden gesteld zo lang hij zijn werk zorgvuldig verricht.

Een beperking van de aansprakelijkheid tot 'zware fout' leidt er dan weer toe dat de regulator niet aansprakelijk zal zijn voor diens lichte fouten. Indien hij aansprakelijk is, zal dit evenwel dan voor alle door zijn fout veroorzaakt schade zijn, zonder cap.

Er lijken geen argumenten voorhanden om de aansprakelijkheid van een regulator te beperken tot diens zware fout. Net zoals andere administratieve overheden moet ook een regulator aansprakelijk gesteld kunnen worden voor diens lichte fout. Aangezien de aan te richten schade daarbij niet steeds valt te overzien - en daarom onbeheersbaar wordt - pleiten wij er tevens voor om de aansprakelijkheid van de regulator eveneens te cappen tot een bepaald maximumbedrag.

\subsection{Aansprakelijkheid van de organen/werknemers van een regulator}

Regulatoren zijn normaliter burgerrechtelijk aansprakelijk voor de schade die wordt veroorzaakt door de fout van hun aangestelden aan derden 'toegebracht in de bediening waartoe zij hen hebben gebezigd'. ${ }^{286}$ Luidens artikel 3 van de wet van ro februari 2003 zijn openbare rechtspersonen - waartoe de regulatoren ook behoren - aansprakelijk voor de schade die hun personeelsleden aan derden berokkenen bij de uitoefening van hun dienst, op de wijze waarop aanstellers aansprakelijk zijn voor de schade aangericht door hun aangestelden, en dit ook wanneer de toestand van deze personeelsleden statutair is geregeld of zij gehandeld hebben in de uitoefening van de openbare macht. ${ }^{287}$ Met deze wetswijziging wenste de wetgever een einde te maken aan de ongelijke behandeling van openbare rechtspersonen op het vlak van hun aansprakelijkheid voor de onrechtmatige daden van hun statutaire personeelsleden, in vergelijking met de aansprakelijkheid van openbare rechtspersonen en privé-aanstellers voor de onrechtmatige daden van hun personeelsleden met een contractuele rechtspositie. ${ }^{288}$

286. Artikel ${ }_{3} 844$, lid 3 BW. Dit vermoeden is onweerlegbaar (zie artikel ${ }_{3} 84$, lid 5 BW).

287. Wet van 20 februari 2003 betreffende de aansprakelijkheid van en voor personeelsleden in dienst van openbare rechtspersonen, B.S. 27 februari 2003.

288. A. Van Oevelen, 'De nieuwe wettelijke regeling betreffende de aansprakelijkheid van en voor personeelsleden in dienst van openbare rechtspersonen', R.W. 2003-2004, nr. 5, I75. 
De persoonlijke burgerrechtelijke aansprakelijkheid van de statutaire personeelsleden van openbare rechtspersonen werd op basis van artikel 2 van de wet van Io februari 2003 beperkt tot de schade veroorzaakt door een opzettelijke fout, een zware fout en een gewoonlijk voorkomende lichte fout. ${ }^{289}$ Een soortgelijke regeling gold, via artikel I8 van de Arbeidsovereenkomstenwet, reeds voor de contractuele personeelsleden van openbare rechtspersonen..$^{29}$ Ook aan deze voordien bestaande ongelijke behandeling van statutaire personeelsleden, op het stuk van hun persoonlijke burgerlijke aansprakelijkheid, in vergelijking met werknemers met een contractuele rechtspositie, werd zodoende een einde gemaakt. ${ }^{291}$

\section{Conclusie}

De opzet van deze bijdrage was een overzicht te geven van de verschillende regulatoren die actief zijn in de Belgische energiemarkten. Aangezien zowel het federale als het gewestelijke niveau bevoegdheden hebben in het kader van het energiebeleid heeft men op beide niveaus tot omzetting van de Europese liberaliseringsrichtlijnen regulatoren opgericht voor de elektriciteits- en aardgasmarkten waarvan de bevoegdheden werden afgebakend in functie van de bevoegdheidsverdeling van de BWHI. In België zijn er vier actief, met name de CREG, de VREG, de CWaPE en BRUGEL. Uit deze bijdrage kan worden afgeleid dat de gewesten op verschillende wijze met eigen accenten het takenpakket van deze regulatoren en het op hen geldende, het door hen uit te oefenen toezicht, hebben ingevuld.

Hoewel het ganse wetgevende pakket op federaal en gewestelijk niveau zeer recent werd afgekondigd, zal dit in de loop van de komende jaren en uiterlijk op 3 maart 20II terug moeten worden gewijzigd omwille van de omzetting van het derde Europese pakket aan energiewetgeving. De bepalingen van het derde pakket geven duidelijk weer dat men er op Europees niveau voor heeft geopteerd om het takenpakket van de nationale regulerende instanties aan de hand van een zeer gedetailleerde opsomming aan taken volledig te stroomlijnen tussen de verschillende lidstaten.

De wijze waarop de regulatoren toezicht uitoefenen op de diverse actoren van de markten, is divers en wordt telkens verschillend geregeld per regulator. De regulatoren houden toezicht, en staan tevens onder toezicht. Het is de vraag hoe dit toezicht zal worden georganiseerd na de implementatie van het derde pakket.

Tegen de beslissingen van een regulator staan verschillende beroepsmogelijkheden bij de rechterlijke instellingen open. De voorbije jaren heeft men op federaal niveau

289. Artikel 2 van de wet van Io februari 2003.

290. Artikel I8 van de Wet van 3 juli 1978 betreffende de arbeidsovereenkomsten, B.S. 22 augustus I978, err. B.S. 30 augustus 1978.

29I. Zie ook A. Van Oevelen, 'De nieuwe wettelijke regeling betreffende de aansprakelijkheid van en voor personeelsleden in dienst van openbare rechtspersonen', R.W. 2003-2004, nr. 5, I6I-I79. 
nog voorzien in een beroepsprocedure tegen welbepaalde beslissingen van de CREG bij het Brusselse Hof van Beroep. Uit recente arresten kan worden afgeleid dat het Hof haar volle rechtsmacht ruimer heeft geïnterpreteerd. Hierbij is het onduidelijk of dergelijke rechterlijke toetsing waarbij het Hof van Beroep van Brussel zich in de plaats gaat stellen van de CREG in overeenstemming is met datgene wat de Europese wetgever beoogde. Verder onderzoek of een prejudiciële vraagstelling aan het Hof van Justitie zal moeten uitmaken in welke mate (beperkt of onbeperkt) een nationale rechter de tarifaire bevoegdheid van de regulerende instanties kan beoordelen. Tenslotte wordt in deze bijdrage nog stil gestaan bij de rol van de regulator ter bescherming van de consument, alsook de aansprakelijkheid van de regulator en diens contractuele personeel. 